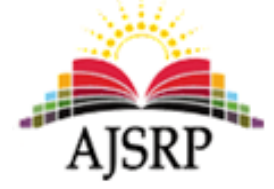

ISSN: 2522- 3399

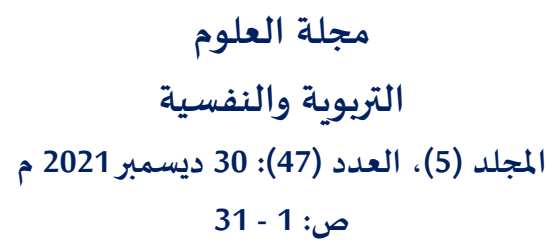

P: 1 - 31

\title{
The Degree of Practicing Administrative Corruption by junior High Schools' Principals within the Green Line and its Relationship to Jop Satisfaction among Teachers and Instructors from their Point of View
}

\author{
Rafat Salama Hmodi \\ Saleh Nasser Olimat
}

Faculty of Education || Yarmouk University || Jordan

\begin{abstract}
The current study aimed to identify the administrative corruption degree in junior high schools within the Green Line in Triangle region cities, and its relationship to jop satisfaction among teachers and instructors from their point of view. This research is a descriptive correlational survey type that was implemented using a two- axis and eight- domain questionnaire as a tool. The sample consisted of (390) participants of teachers and instructors. The sample was selected randomly during the academic year $2020 \backslash 2021$.

The results of the study showed that administrative corruption, from the sample's point of view, obtained an overall average (3.25 out of 5) with a practice rating of (medium). As for the sub- domains; The corruption related to employees got the highest average of (3.75) with a rating of (large), then material with an average of (3.31) then transactions with an average of (3.17) and finally corruption in facilities with an average of (3.05), all of them with a rating of practice, (medium). As for the occupation satisfaction axis of teachers and instructors, it was obtained an overall average (3.27 out of 5) with a degree of satisfaction (medium). The level of the domains; Satisfaction with the school environment got the highest average (3.66), with an average (significant) degree, then satisfaction with qualification and training with an average (3.21), then satisfaction with leadership with an average (3.04), and finally financial satisfaction with an average (2.94), all with a degree of satisfaction (medium). The results also showed a relationship between occupation satisfaction and administrative corruption with a negative relationship that amounted to $(r=-0.29 ; p<0.1)$, and corruption is statistically significant.
\end{abstract}

The study also showed that there are statistically significant differences between the average estimates of the study sample of the level of their estimates of administrative corruption and their occupation satisfaction in the four areas, according to the gender variable in favor of females, and according to the qualification variable in favor of the bachelor's holders, and according to the experience variable in favor of those with less experience, and according to the school variable in favor of teachers and instructors from private schools.

Based on the results of the study, the researcher presented a set of recommendations to reduce administrative corruption and increase the satisfaction of teachers and instructors, including: Working to provide an organized educational environment in educational institutions that reflects the state of interdependence between the goals put forward by the administration and teachers and effective participation between the different parties to achieve the desired goals and bring out a future generation. It was also suggested to conduct complementary research on the subject.

Keywords: Relationship, Administrative Corruption, Job Satisfaction, Junior high schools' Principals, Teachers and .Instructors, The Green Line. 
درجة ممارسة الفساد الإداري لدى مديري المدارس الإعدادية وعلاقته بالرضا الوظيفي للمعلمين والمرشدين في منطقة المثلث داخل الخط الاخضي مندر من وجهة نظرهم

\author{
رأفت سلامة حمودة \\ صالح ناصبر عليمات \\ كلية التربية || جامعة اليرموك || الأردن ناهير
}

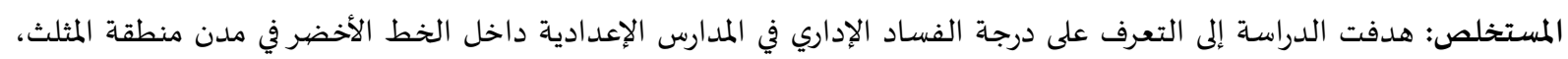

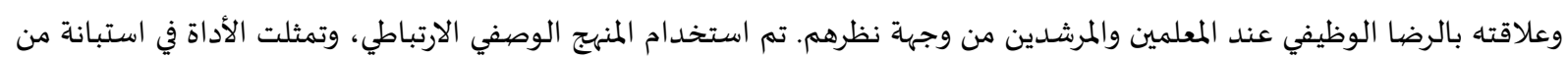

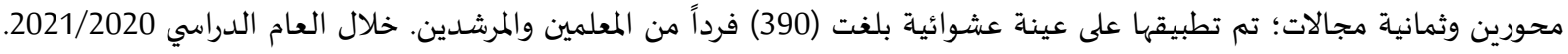

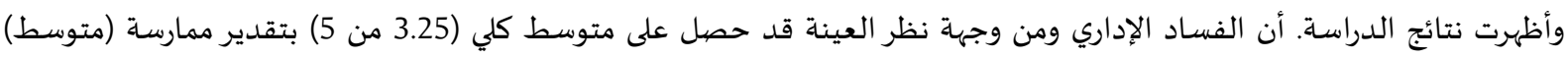

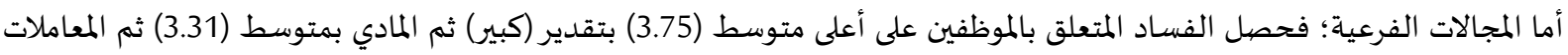

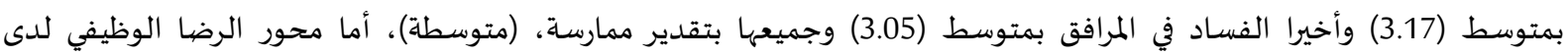

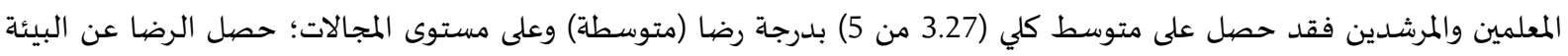

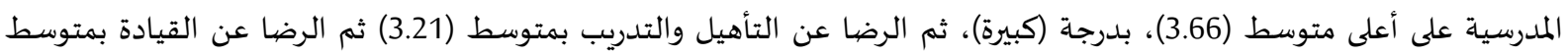

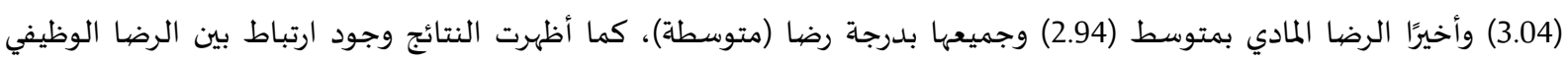

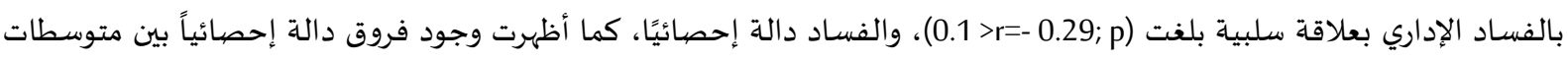

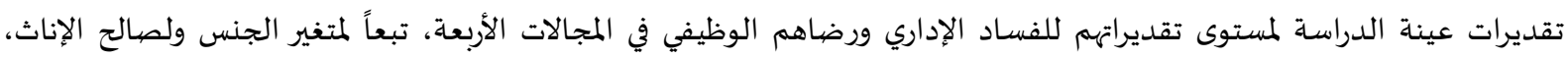

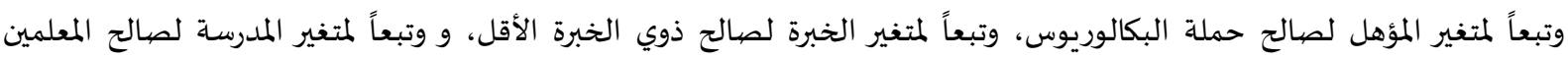

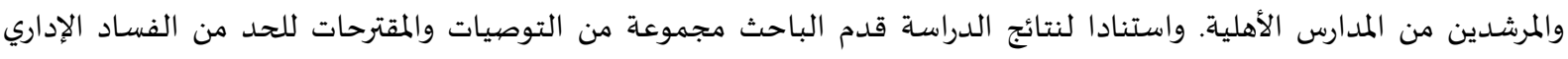

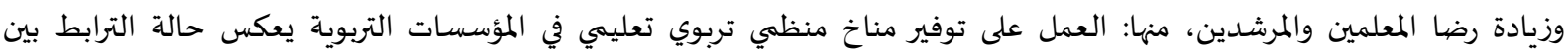

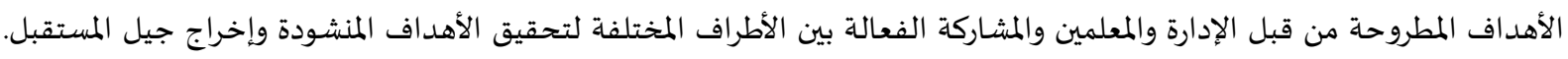

كما اقترح إجراء أبحاث مكملة في الموضوع.

الكلمات المفتاحية: علاقة، الفساد الإداري، الرضا الوظيفي، مديرو المدارس الإعدادية، المعلمين والمرشدين، الخط الأخضر.

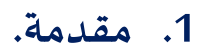

يُعد بناء جيل ناشئ إداري قادر على مواجهة متطلبات الحياة وتحديات العصر مطلباً ملحاً وغاية ضرورية.

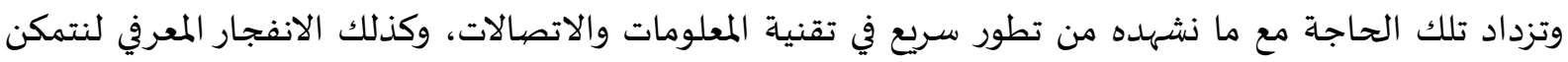

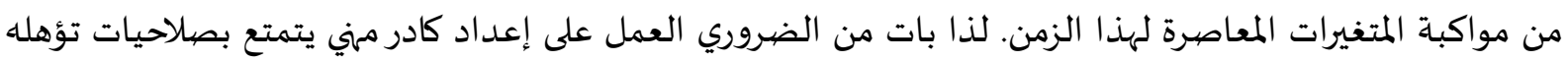

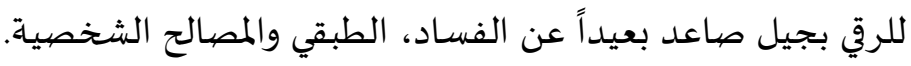

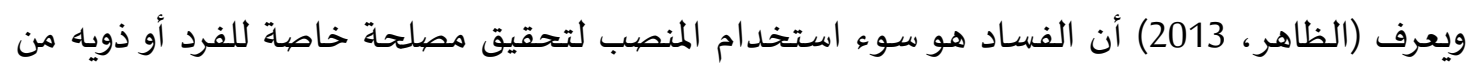

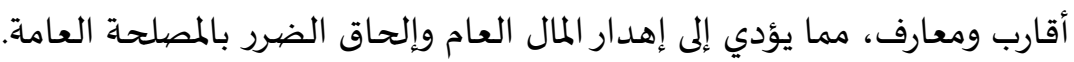

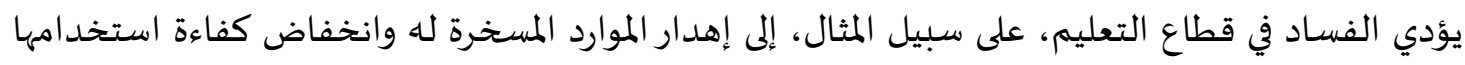

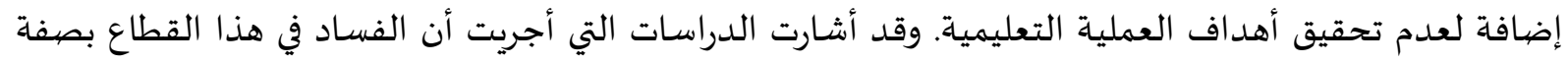

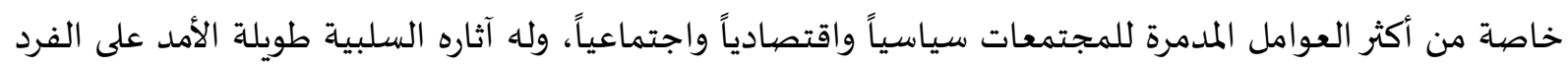

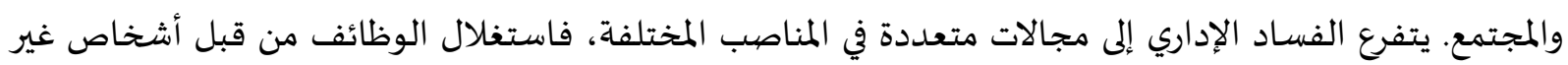

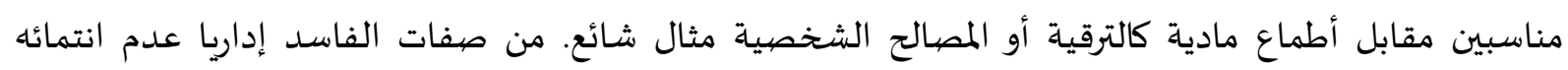

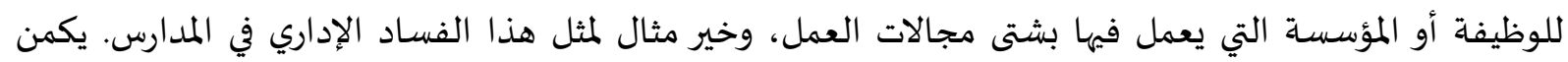


السبب الرئيسي لهذا الفساد في تعيين إداريين غير أكفاء وغير مؤهلين يقوموا باستخدام الوظيفة بطريقة سيئة. عادة

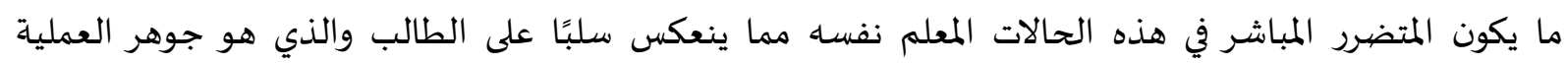

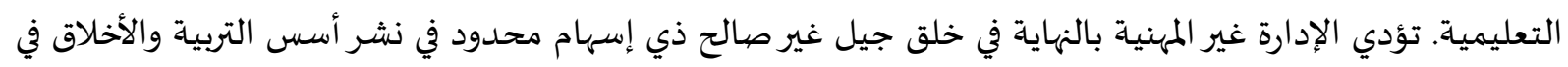
المجتمع (خالد، 2007). يؤدي الفساد الإداري في المدارس إلى عدم استغلال الموارد التعليمياة، التأثير السلبي وانخفاض الكفاءات في

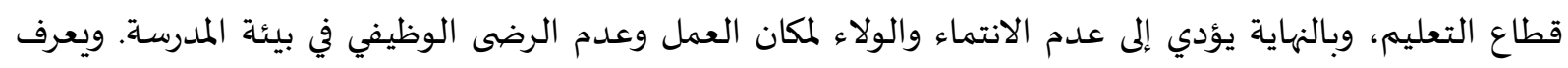

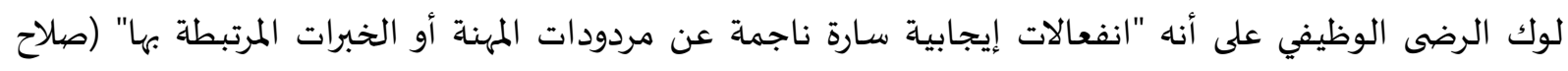

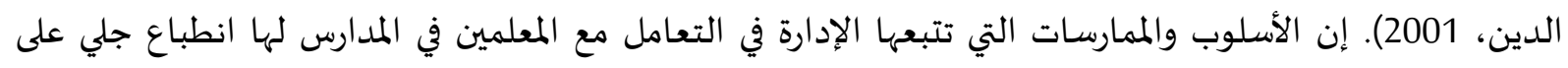
البيئة التربوية والتعليمية. الأمر الذي ينعكس على المناخ داخل المدرسة وشعور المعات المعلمين بالانتماء والثقة وبالنهاية

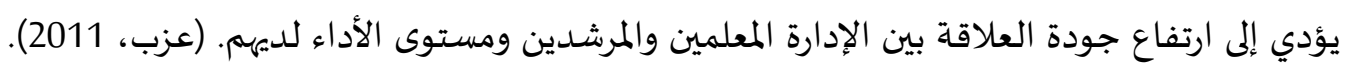

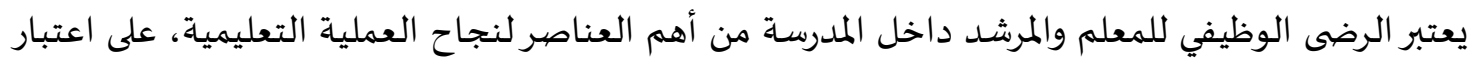
ان أداء المعلم يتأثر بصورة كبيرة بمقدار رضاه عن هذه الوظيفة في تلبية احتياجاته المادية، النفسية والاجتماعية.

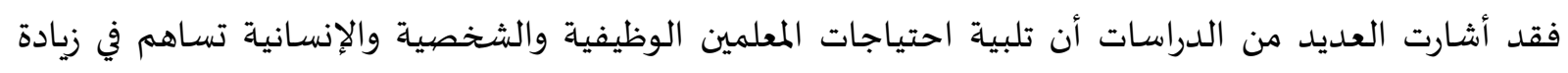

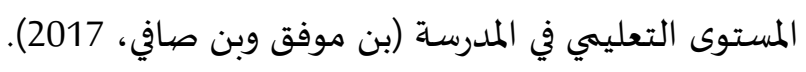

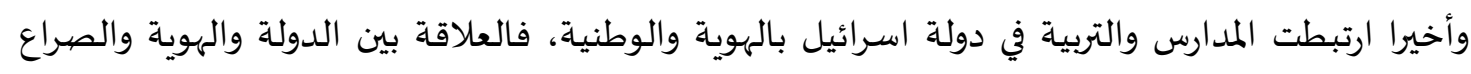

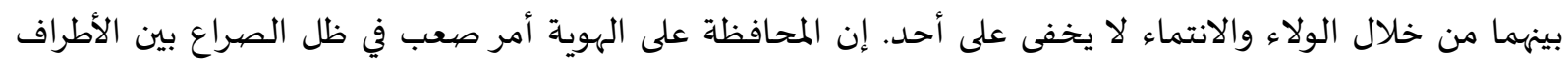

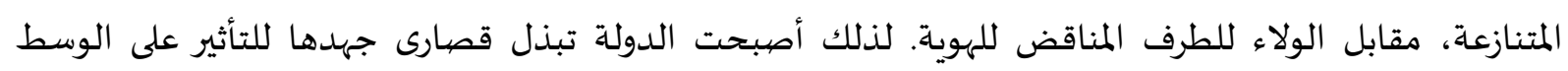

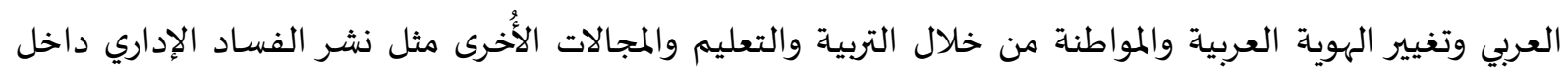

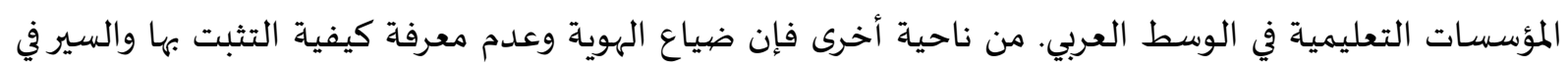
المسار الصحيح للخروج إلى بر الأمان أصبح تحديا آلحرًا.

مشكلة الدراسة:

من خلال عمل الباحث في مجال التربية والتعليم والاطلاع على دراسات سابقة، التي أظهرت نتائجها وجود

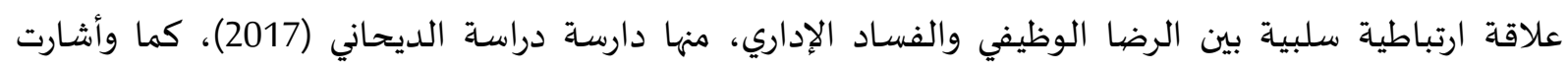

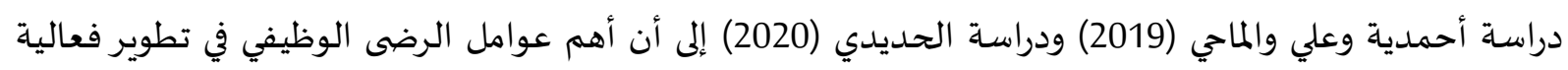

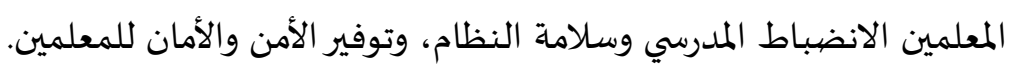

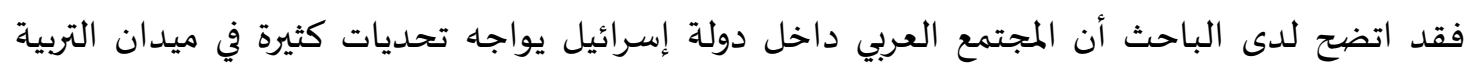

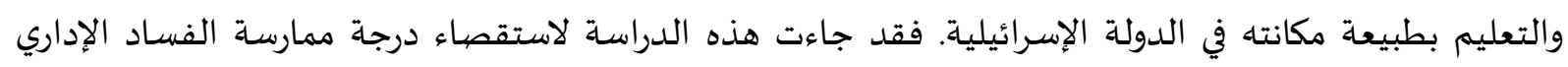

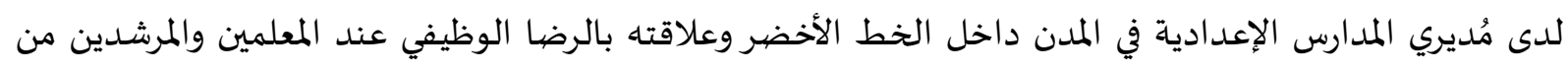

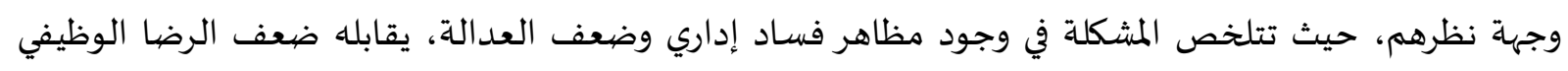

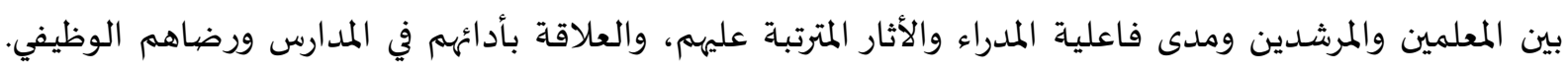

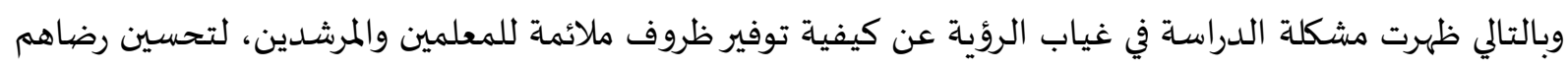

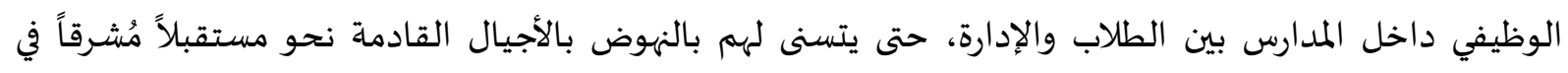

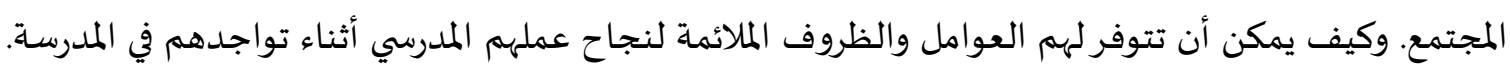


تتحدد مشكلة الدراسة في الأسئلة الآتية: 1- ما درجة ممارسة الفساد الإداري لدى مديري المدارس الإعدادية داخل الخط الأخضر في لواء المركز من وجهة نظر المعلمين والمرشدين؟

2- ما مُستوى الرضا الوظيفي للمعلمين والمرشدين في المدارس الإعدادية داخل الخط الأخضر من وجهاة نظرهم؟

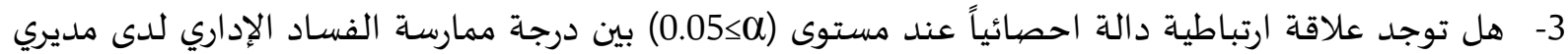
المدارس الإعدادية والرضا الوظيفي للمعلمين والمرشدين؟

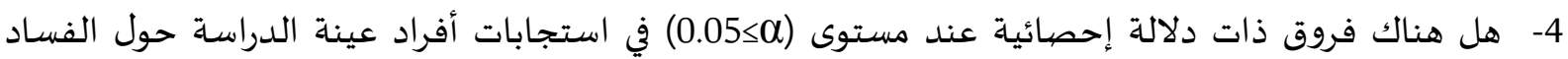

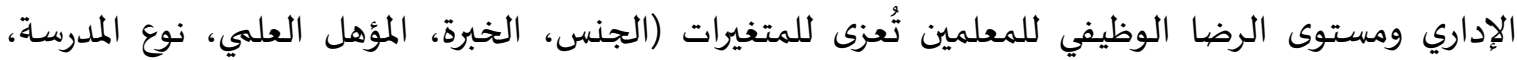

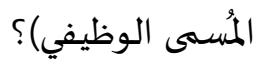

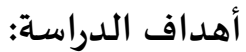

$$
\text { تهدف الدراسة لتحقيق الأهداف التالية: }
$$

1- التعرف على درجة وجود الفساد الإداري في المدارس الإعدادية داخل الخط الأخضر من وجهة نظر المعلمين

والمرشدين.

2- التعرف على درجة الرضا الوظيفي لدى معلمي ومرشدي المدارس الإعدادية في منطقة المثلث داخل الخط

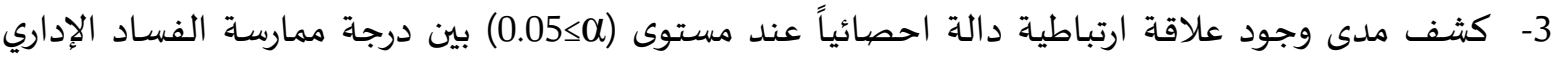

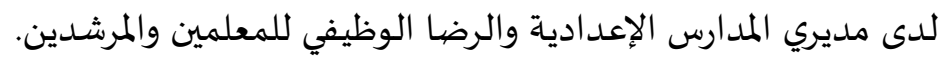

4- - كشف أثر متغيرات الدراسة (الجنس، المؤهل العلمي، سنوات الخبرة، المُسمى الوظيفي، نوع المدرسة) في

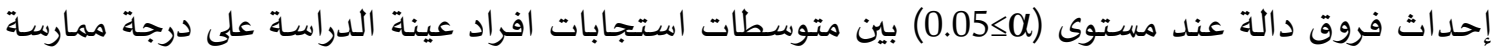
مديري المدارس الإعدادية في منطقة المثلث داخل الخط الأخضر للفساد الإداري. وعلى رضا الوظيفي عند المعلمين والمرشدين في تلك المدارس.

أهمية الدراسة:

اتضحت أهمية دراسة التعرف على مستوى الفساد الإداري في المدارس الإعدادية في مدن المركز داخل الخط الأخضر في دولة إسرائيل، وتأثيره على الرضا الوظيفي لدى المعلمين، من خلال ما يلي:

اولاً الأهمية النظرية

- ـ ـيؤمل الباحث أن تساهم هذه الدراسة في أثراء المعرفة في مجال الإدارة التربوية، من خلال تقديم اطاراً نظرياً

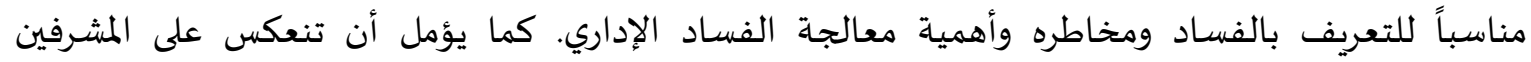

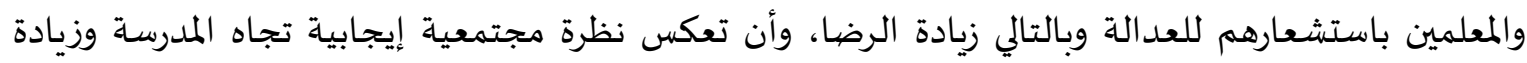

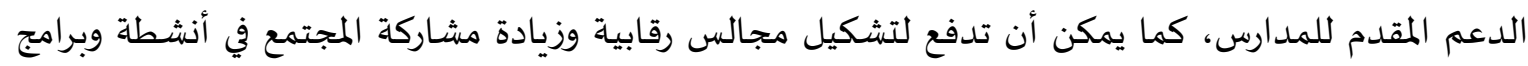
المدرسة والإشراف عليها، بما يحد من الفساد. 
ثانياً الأهمية الإجرائية:

- - تبرز أهمية هذه الدراسة في إعداد أدوات الدراسة وتطبيقها وما ينتج عنها من نتائج وتوصيات

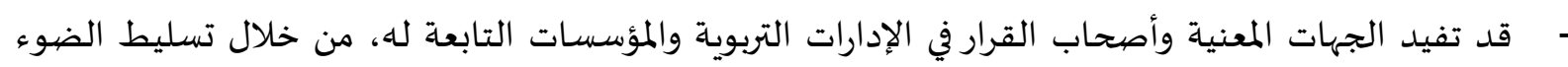

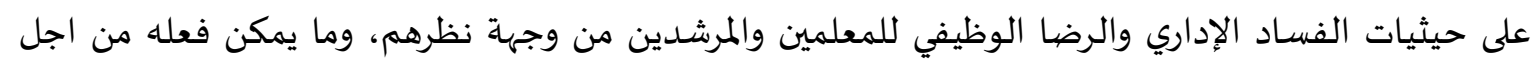

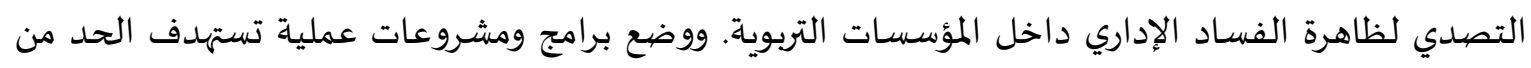

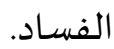

قد تفيد الجهات الرقابية في الإدارة التعليمية لوضع لوائح وإصدار تشريعات لتجريم الفساد ووضع عقوبات رادعة. كما يؤمل الاستفادة من النتائج والتوصيات التي ستخلص اليها الدراسة في فتح المجال امام الباحثين وطلبة الدراسات العليا في مختلف المجالات التربوية.

حدود الدراسـة: ( حمتهي

تقتصر الدراسة على الحدود الآتية:

الحدود الموضوعية: الفساد الإداري وعلاقته بالرضيا الوظيفي. الحدود البشرية: عينة من المعلمين والمرشدين في المدارس الإعدادية المدادية.

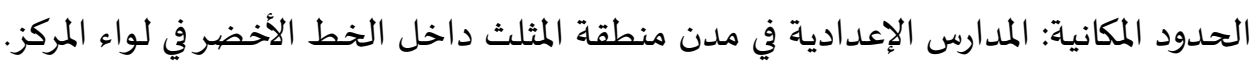

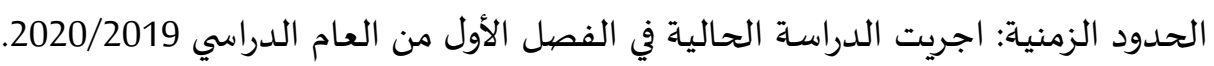

مصطلحات الدراسـة: اشتملت الدراسة الحالية على مجموعة من التعريفات أهمها:

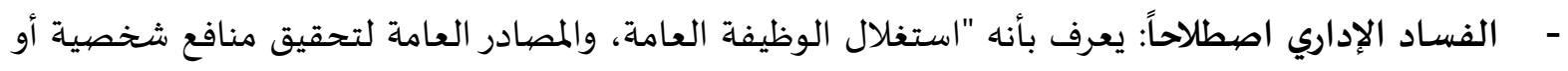

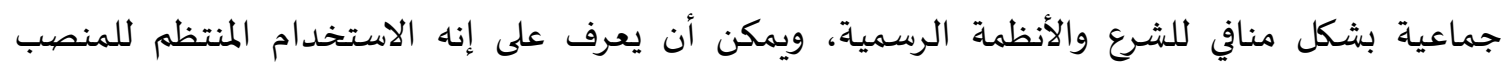

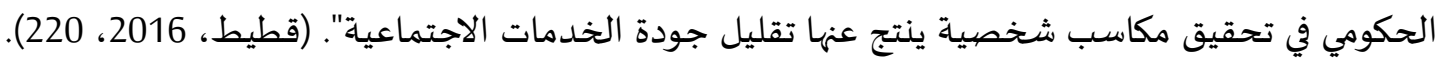

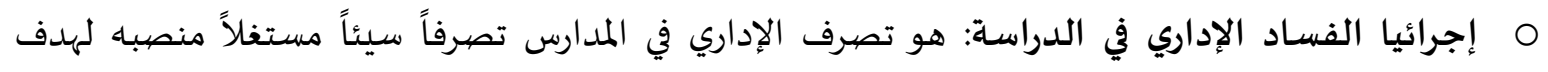

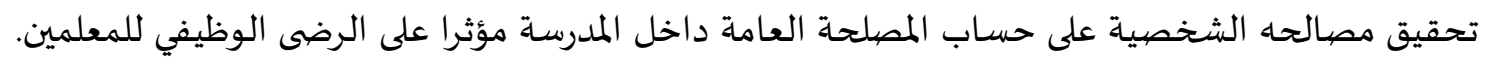

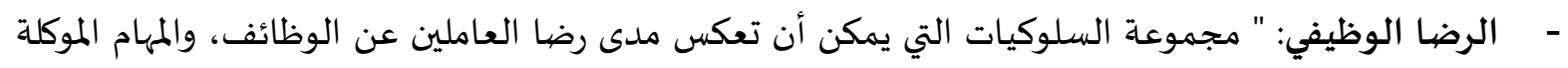

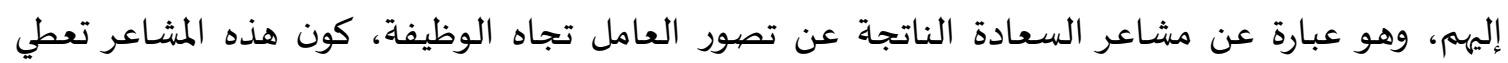

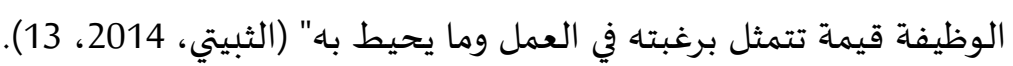
O التعريف الإجرائي للرضا الوظيفي: مدى الرضا الوظيفي عند المعلمين داخل المدارس من خلال وجود فساد إداري. - لواء المركز: "هي منطقة إسرائيلية مركزها بمدينة الرملة وتشكل المنطقة الوسطى معظم مساحتها، من ضمنها

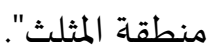
- الخط الأخضر: "هو لفظ يطلق على الخط الفاصل بين الأراضي المحتلة عام 1948 والذي أصبح فيما بعد

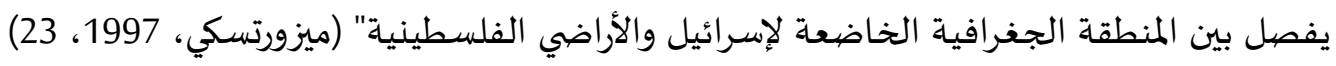


إن ظاهرة الفساد الإداري ظاهرة طبيعية في المجتمعات الرأسمالية حيث تختلف درجات هذا الفساد إلى

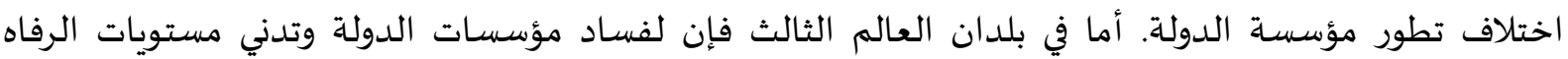

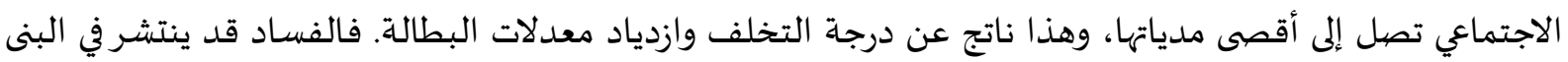

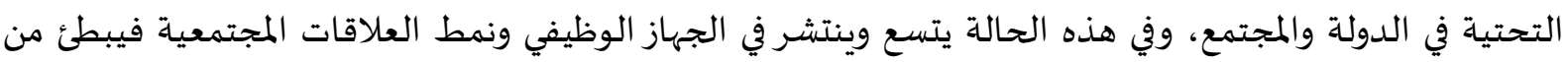

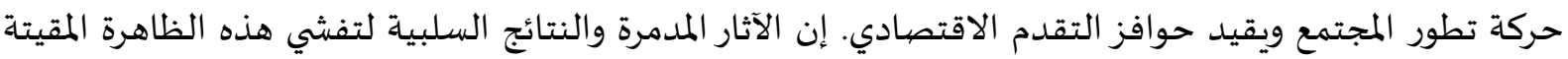

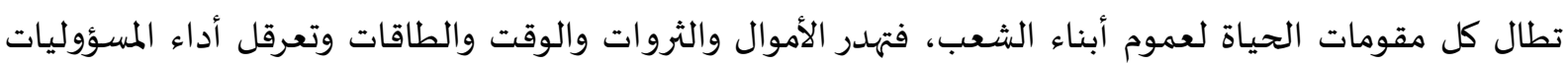

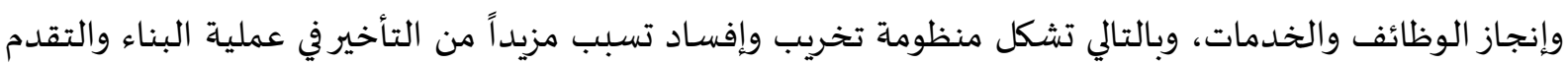
ليس على المستوى الاقتصادي والمالي فقط، بل في الحقل السياسي والاجتماعي والثقافي، ناهيك عن مؤسسات ولتهات ودوائر

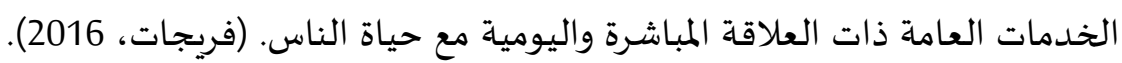

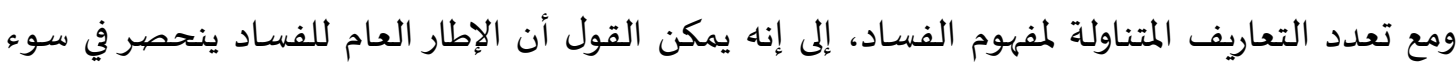
استعمال السلطة أو الوظيفة العامة وتسخيرها لقاء مصالح ومنافع تتعلق بفرد أو بجماعة معينة.

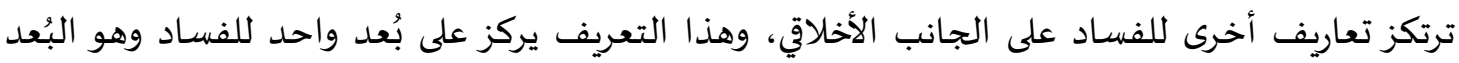

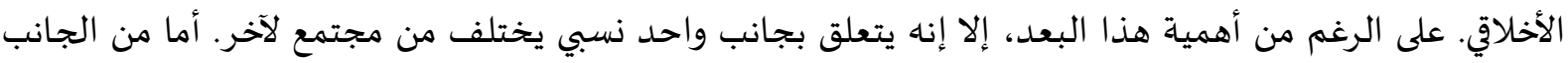

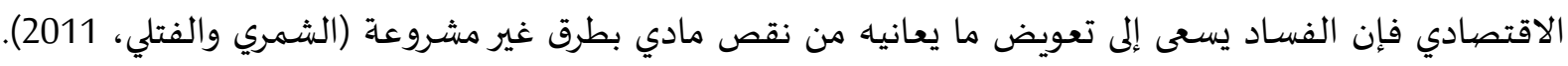

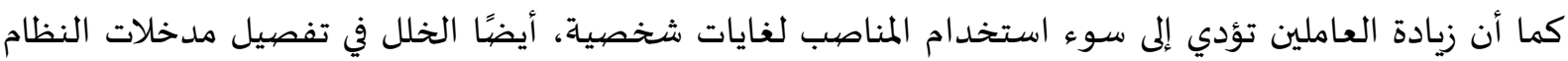

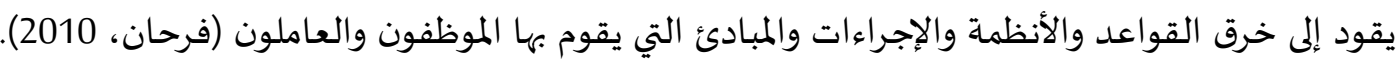

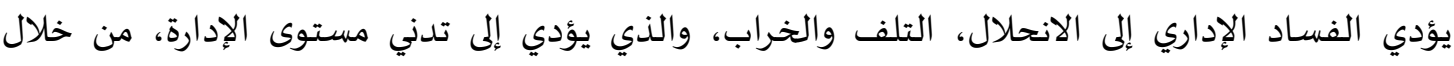

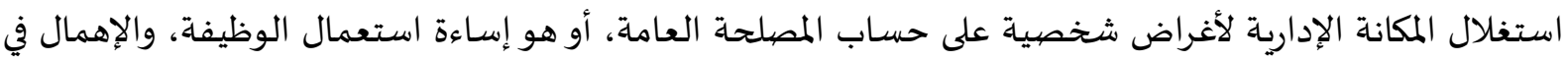

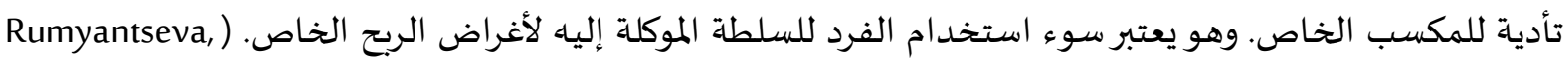

يمكن تحديد أشكال الفساد الإداري بما يلي:

الرشوة: وهي إعطاء أو تلقي شيء ذي قيمة (نقدية أو غير نقدية) في إطار معاملة تتسم بالفساد.

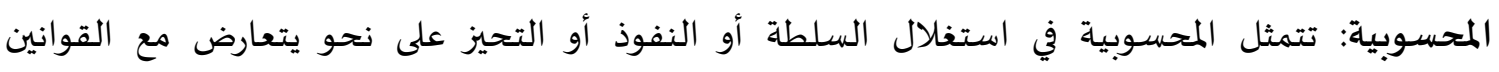

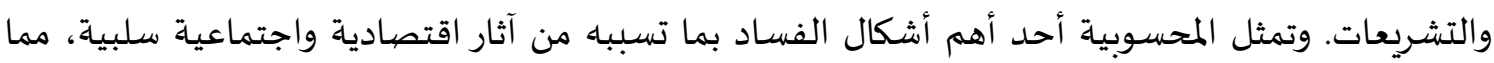

$$
\text { يخلق الشعور بالظلم والقهر الاجتماعي. }
$$

الواسطة: تعتبر الواسطة من الظواهر الاجتماعية العامة التي تسود معظم المجتمعات. تعرف الواسطة على

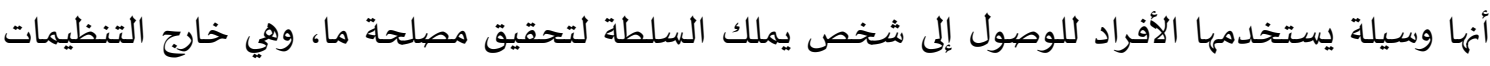

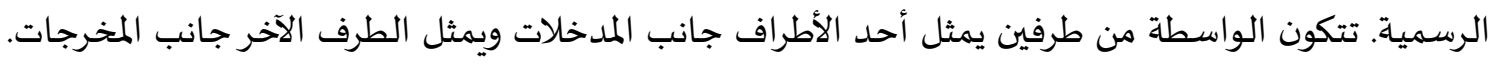
الاحتيال (النصب): الاحتيال هو جريمة اقتصادية تتضمن نوعا من الغش والخداع. ويعرف الاحتيال على أنه القيام بتشويه أو تزييف المعلومات والحقائق لتحقيق منافع خاصة (الشمري والفيات الفتلي، 2011). 


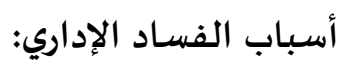

للفساد الإداري أسباب عديدة قد تؤثر بشكل فردي وقد تكون مجتمعاة، نلخصها فيما يلي (فرحان، 2010):

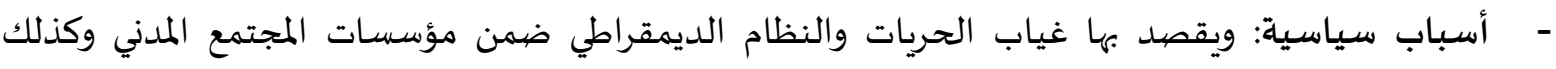

$$
\text { ضعف الإعلام والرقابة. }
$$

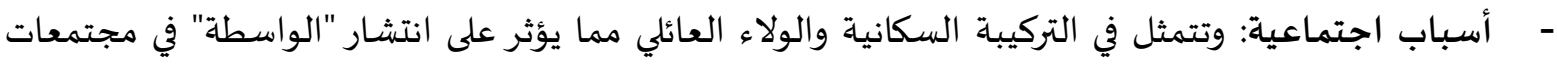

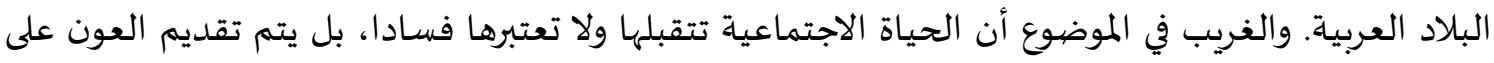

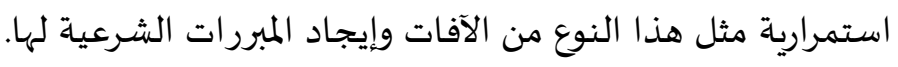

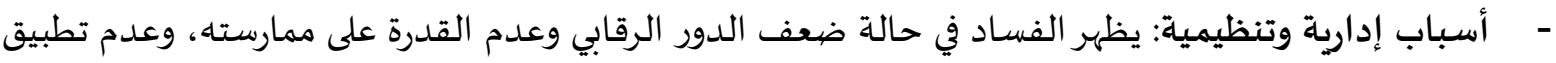
القانون بالإضافة إلى عدم تفعيل صلاحيات الأجهزة الرقابية على أعمال الجهاز التنفيذي ومحاسبة التهاية المخالفين.

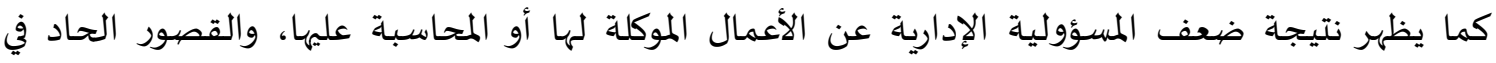

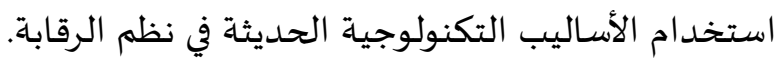

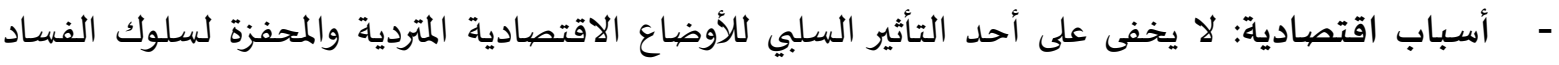

$$
\text { وكذلك ارتفاع تكاليف المعيشة. }
$$

الآثار السلبية للفساد الإداري:

أن هذه الظاهرة لها العديد من الآثار السلبية، كتأثيرها على الجانب المادي كذلك الجانب الأخلاقي،

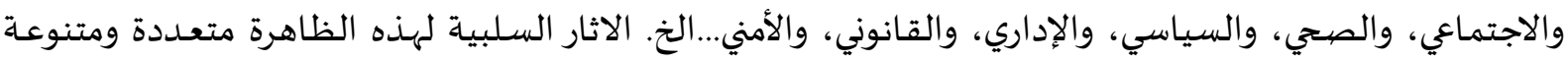

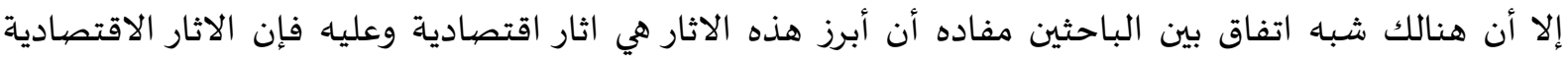

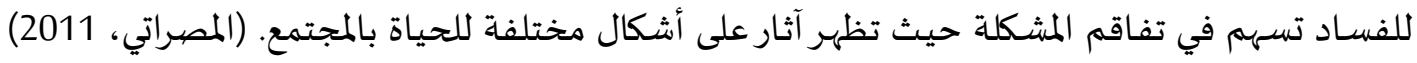

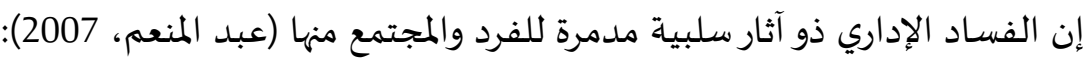

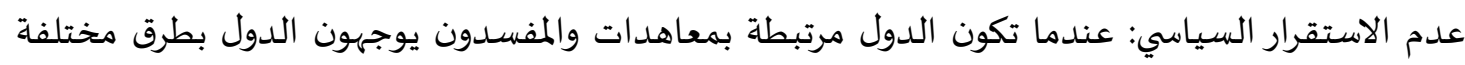
بإنشاء مشاريع لا تمت بصلة إلى التنمية أو التطوير. التأثير على صانع القرار السياسي: يؤدي الفساد إلى الابتعاد عن القرارات السليمة في اتخاذ صانع القرار

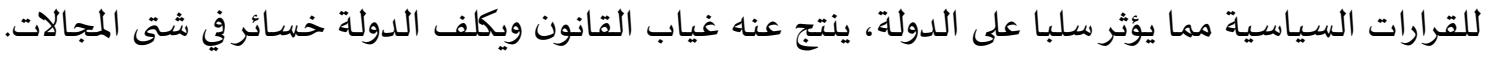

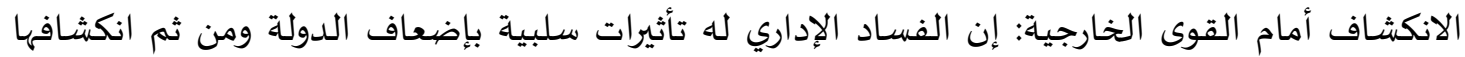

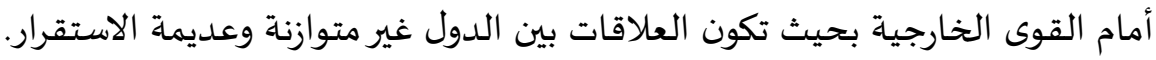

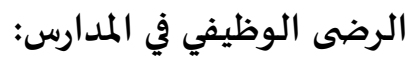

أستعرض هنا الجانب الآخر من الدراسة والذي يخص تأثير الفساد الإداري على الرضى الوظيفي. تعريف

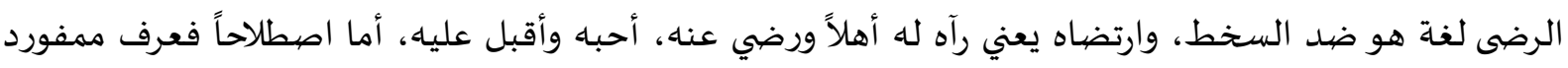

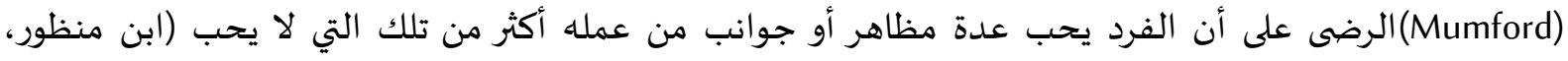

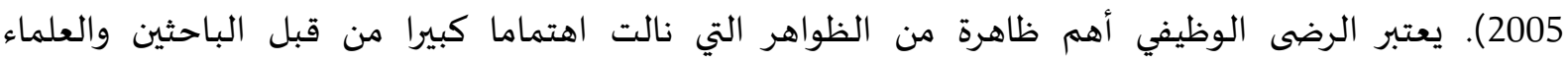

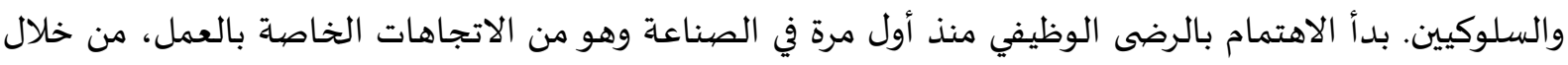

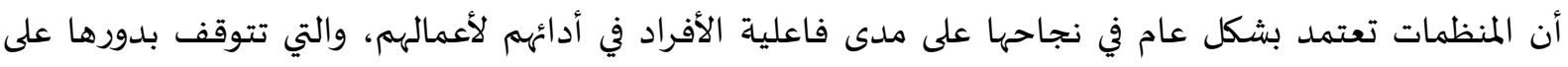


درجة رضائهم ومستوى حماسهم للعمل. الأمر الذي يؤكد أهمية العنصر البشري في حياة واستمرار المنظمات مع ضرورة الاهتمام باه. (جمال الدين، 2002).

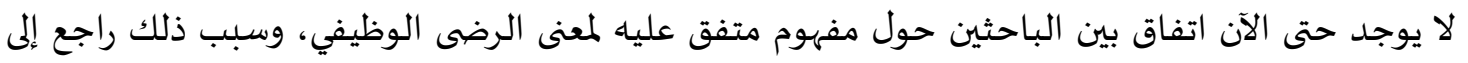

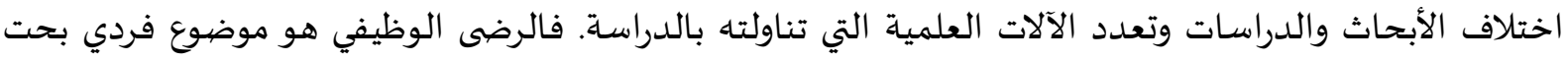
ويمكن أن يكون رضى شخص عدم رضى لشخص آخر. فيما يعرف ستون الرضى الوظيفي بأنه الحالة التي يتكامل

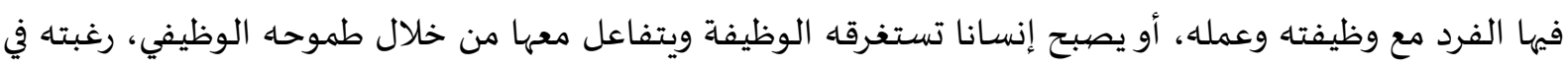
النمو والتقدم وتحقيق أهدافه الاجتماعية من خلالها. أما الأستاذ لولر فيقول إن حصول الفئ الفرد على المزيد كما كان يتوقع يجعله أكثر قناعة ورضى وكثيرا ما تشير

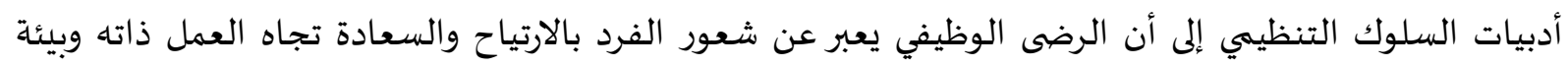

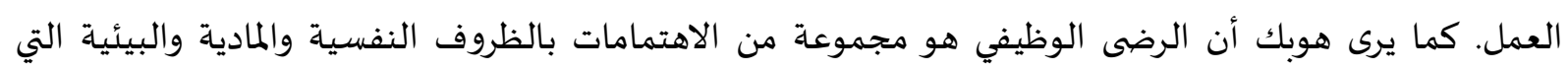

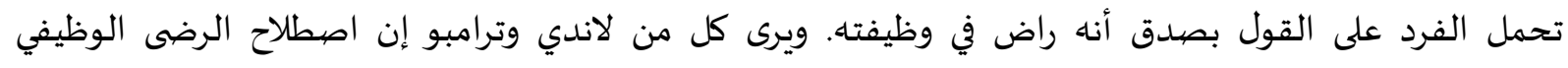

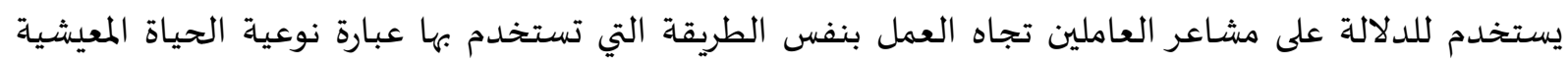
لوصف ردود فعل أو انطباعات الفرد عن الحياة بشكل عام (صلاح الدين، 2001).

\section{أنواع الرضا الوظيفي}

هناك من يصنف الرضا الوظيفي إلى قسمين أو نوعين وهما :

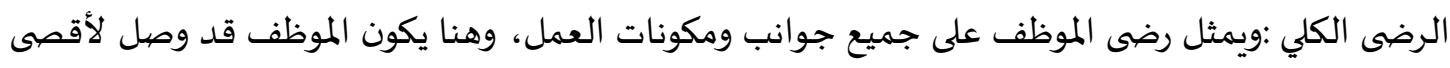

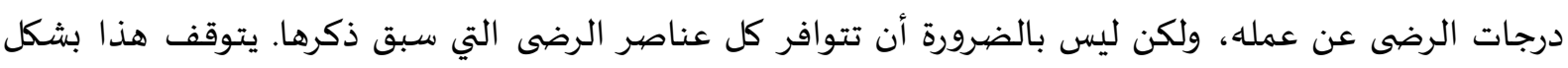

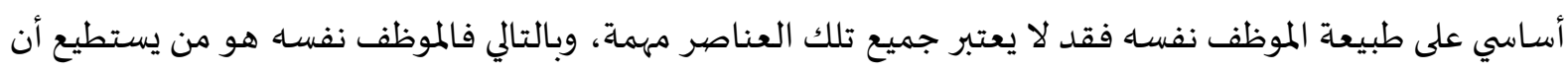
يحدد تلك العناصر التي تتوافق معه (Esther\& Helen\&Genelyn,2019).

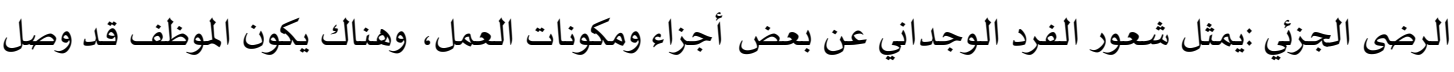

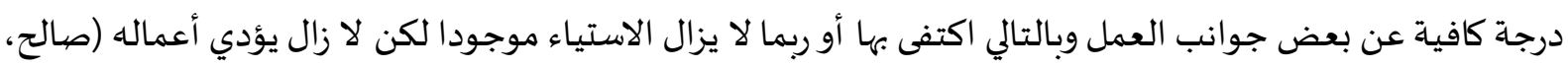

وسـائل تعزيز الرضى الوظيفي:

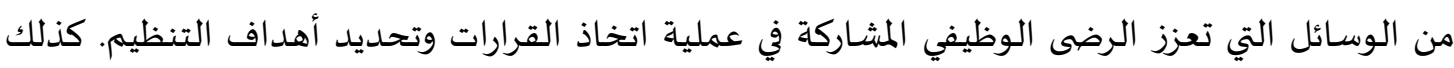

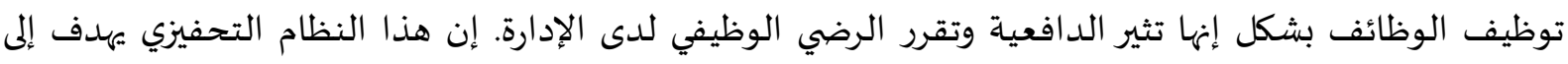
رفع مستويات الكفاءة والفعالية والإنتاجية ومعنويات مفتشي الإدارة بصفة عامة (جمال الدين، 2002).

عوامل حدوث الرضى الوظيفي: يعمل الناس لكي يصلوا إلى أهداف معينة وينشطون في أعمالهم لاعتقادهم أن الأداء يحقق لهم الأهداف

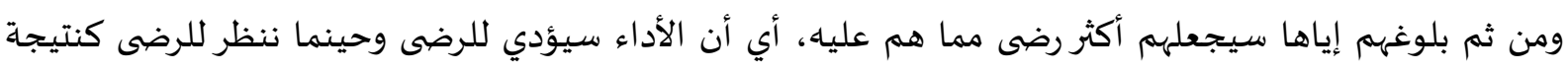
للكشف عن الكيفية التي يتحقق بها والعوامل التي تسبقه، سنجد أن تلك العوامل التي بينها الباحث سعيد التهاديد (2012) من خلال تنظيم نسق من التفاعلات يتم على النحو التالي:

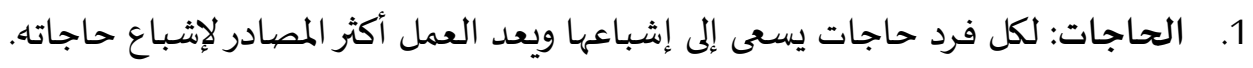


2. الدافعية: تولد الحاجات قدرا من الدافعية تحث الفرد على التوجه نحو المصادر المتوقع اتباع تلك الحاجات

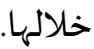

3. الأداء: تتحول الدافعية إلى أداء تنشط الفرد وبوجاه خاص في عمله، اعتقادا منه أن هذا الأداء وسيلة إلى إشباع

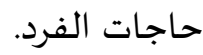

4. - الإشباع: يؤدي الأداء الفعال إلى إشباع حاجات الفرد.

5. الرضى: إن بلوغ الفرد مرحلة الإشباع من خلال الأداء الفعال في عمله يجعله راضيا عن العمل بادياء الفتباره الوسيلة التي يتسنى من خلالها إشباع حاجاته.

6. ترك الخدمة: يمكن اعتبار حالات ترك الخدمة التي تتم بمبادرة الفرد كمؤشر لدرجة الرضى التهى العام عن العمل، إذ ينظر لبقائه في الوظيفة كمؤشر يدل مدى ارتباطها بعال بعمله (محمودية، 2001).

الاستخدامات الأساسية لتحليل الوظائف:

يستخدم تحليل الوظائف كأساس لتقييم الوظائف وتحديد أهميتها النسبية ومن ثم تحديد الاجر أو الراتب.

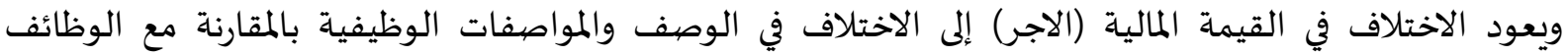

الأخرى. (باجاة، 2014)، ومن الاستخدامات الأساسية لتحليل الوظائف عند الموظفين: (درة والصباغ، 2010): الاختيار والتأهيل: يستخدم تحليل الوظائف كأساس لوضع نظام سليم لاختيار الأفراد الذين يمتلكون القدرات والمؤهلات وتنطبق علههم الشروط الواجب توافرها طبَّا للمواصفات الوظيفية. وكذلك يستند إلى تحليل الوظائف في تحديد ووضع برنامج التأهيل للعاملين الجدد. التدريب والتنمية: تفيد المعلومات التي يتم التوصل إليها من خلال تحليل الوظائف في تحديد الاحتياجات

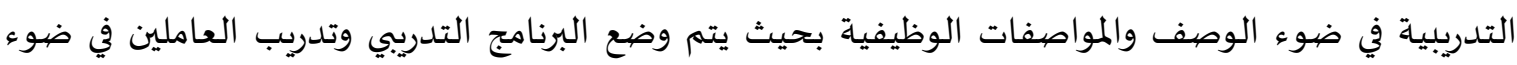
مستوى الأداء والمهارات المطلوبة. الأجور والمرتبات: لا بد من إعطاء الموظف الأجر العادل الذي يتناسب مع أهمية العمل الذي يقوم به. تستخدم

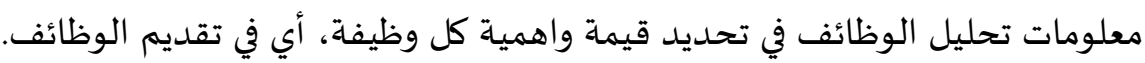
حماية العاملين: يتم التعرف على أخطار الوظيفة وأخطار ظروف العمل من خلال تحليل الوظيفة بحيث يتم

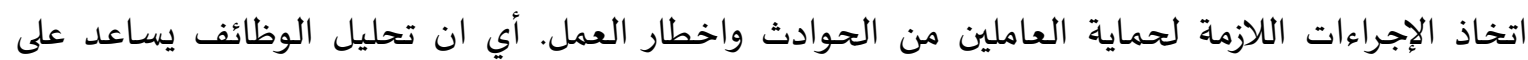
تشخيص حوادث العمل وكيفية تجنها. تخطيط الموارد البشرية: الهدف الأساسي من التخطيط للموارد البشرية هو تحديد احتياجات المنظمة من الموارد البشرية كماً ونوعا. ولا يمكن تحديد ذلك الا في ضوء تحليل الوظائف الوفئ بحيث يمكن التعرف على نوعية الموارد البشرية المطلوبة وكذلك عددها. تقييم الأداء: يتم تحديد مستوى الأداء المطلوب بناء على الصف والمواصفات الوظيفية وبحيث يتم تقييم أداء العاملين في ضوء ذلك. في ضوء هذا المستوى الذي وضع أساسا نتيجة تحليل الوظائف يمكن تحديد نوعية الادية الاعمال المطلوبة والقدرات التي يجب ان تستخدم في الوظيفة. (درة والصباغ، 2010)

ثانياً- الدراسات السابقة: تضهمن هذا الجزء من الفصل الثاني عرضا للدراسات السابقة التي تناولت في محورها مؤثرات دراستنا الفساد الإداري والرضى الوظيفي في مجال الادارة التربوية. 
- قام الجاعوني (2009) بدراسة تطبيقية عن العلاقات بين الفساد الإداري والتنمية البشرية وهدفت إلى قياس

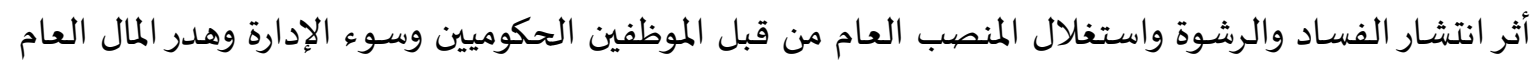

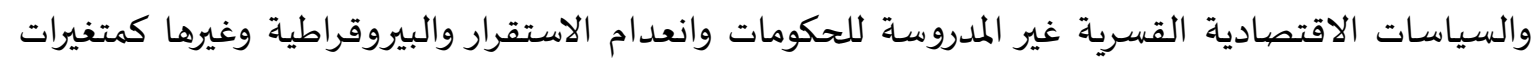

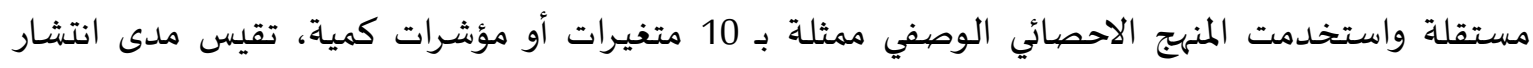

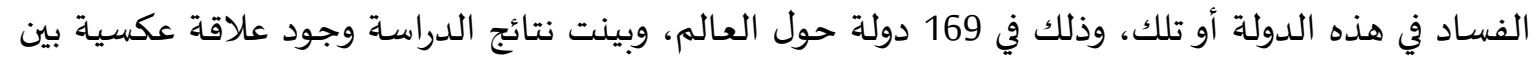

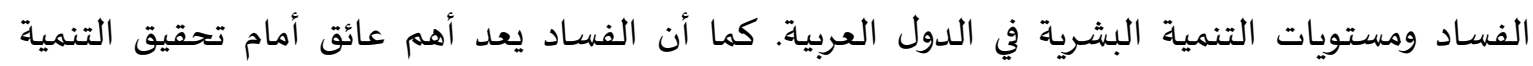

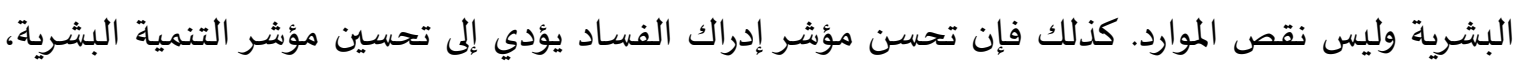
وقد استنتجت الدراسة أيضا أن هناك ارتباط طردي بين مستوى الفساد ومستوى الفقر في المجتمع.

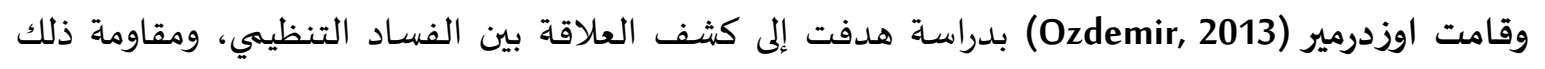

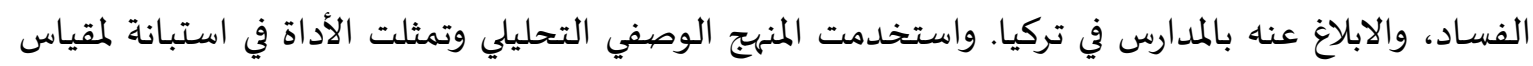

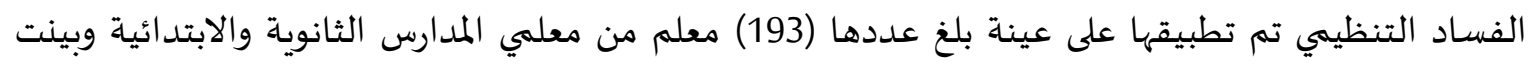

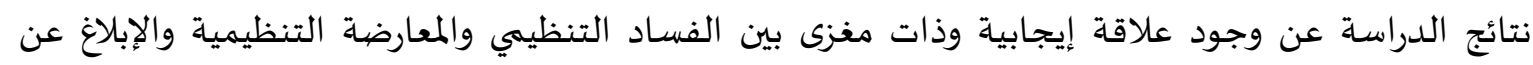

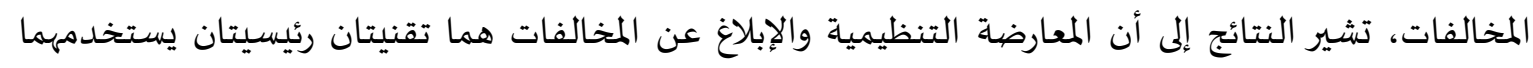
المعلمون لمقاومة الفساد التنظيمي في المدارس. سعت دراسة قطيط (2016) للوصول إلى الوسائل الضرورية لردع ومنع الفساد الإداري خاصية في المدارس.

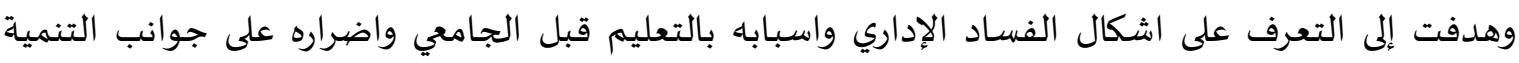

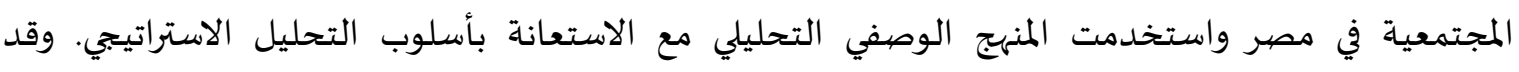

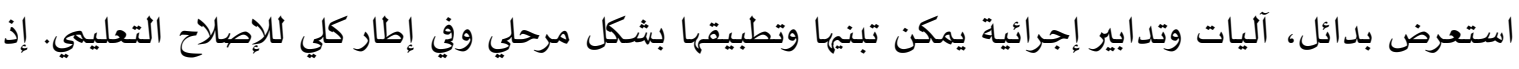

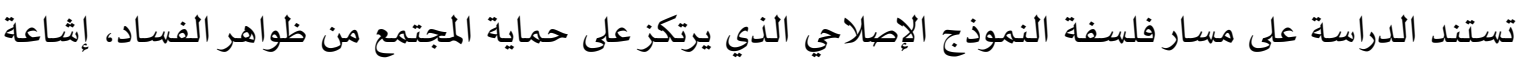

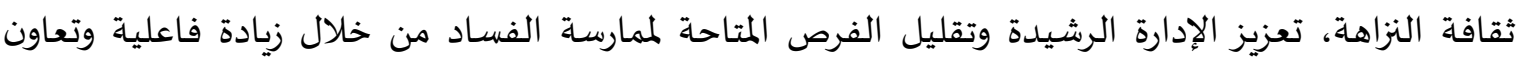

مؤسسات المجتمع مع المؤسسات التعليمية. وأجرى الديحاني (2017) دراسة هدفت إلى التعرف على تأثير أبعاد الرقابة والشفافية الإدارية في مكافحة

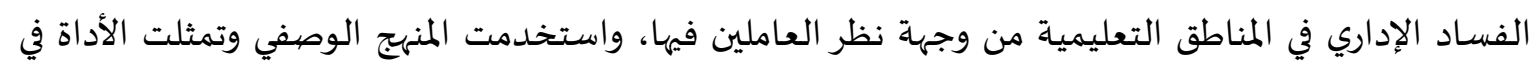

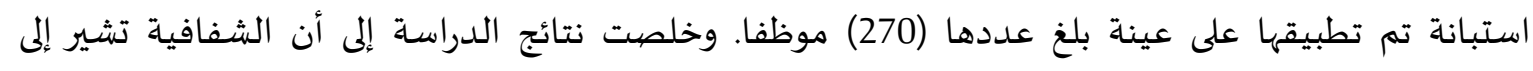

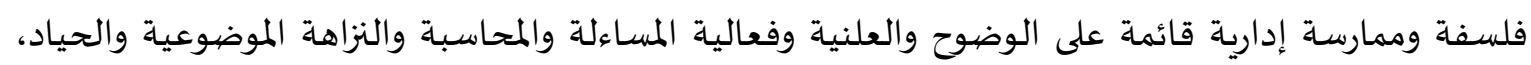
هي مدخل مهم للكشف عن مواطن الفساد، ومكافحة الواسطة والمحسبوبية. وهدفت دراسة الحديدي (2020) إلى التعرف على دور الحكومة الإدارية في مكافحة الفساد الإداري في وزارة

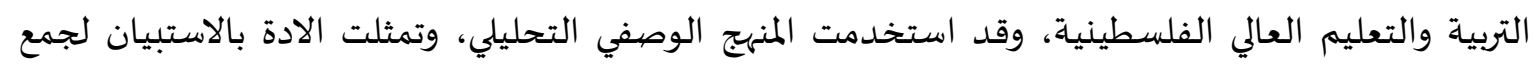
المعلومات، تم تطبيقها على عينة من (180) موظفاً وموظفة في وزارة التربية والتعليم العالي، وبينت النتائج وأنه الته

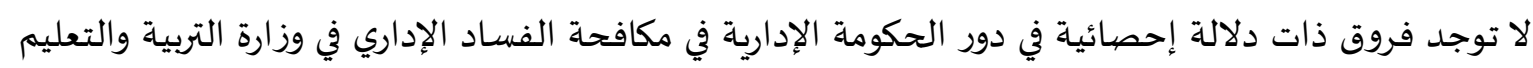

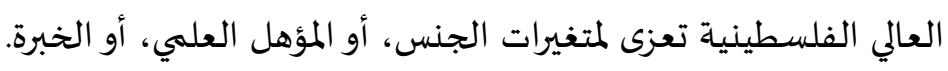


ب- دراسـات تتعلق بالرضيا الوظيفي:

وهدفت دراسة شيلا وسيفيلا (Shila\& Sevilaa,2015) إلى الكشف عن مستوى الرضى الوظيفي لدى المعلم

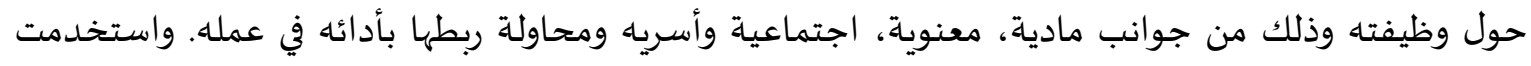

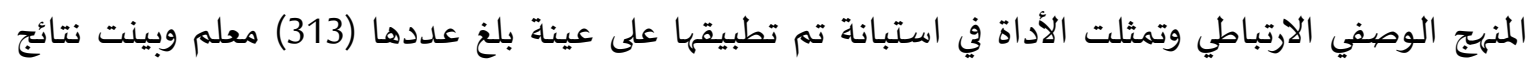

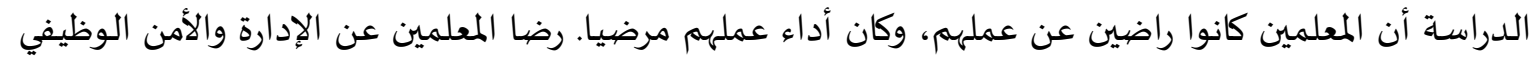

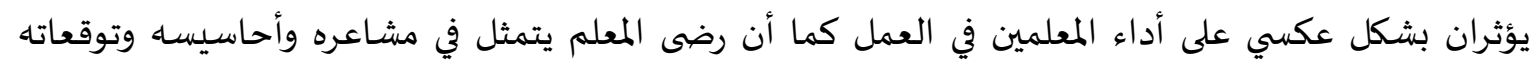

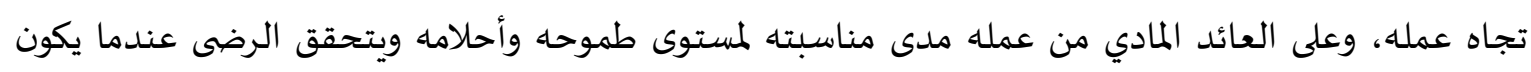

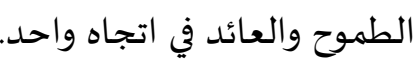
وأجرى بن موفق وبن صافي(2016) دراسة في الجزائر هدفت إلى التعرف على مستوى الرضا الوظيفي لدى المعاد

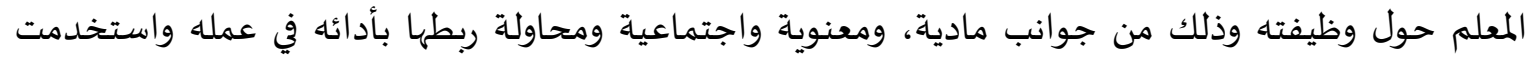

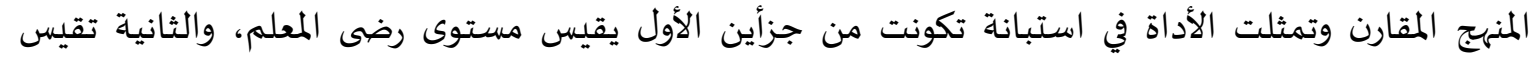

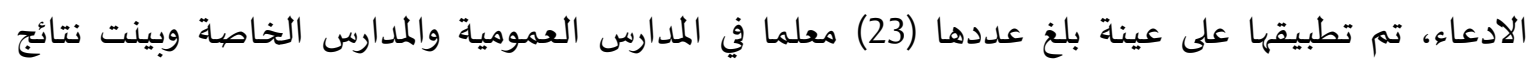

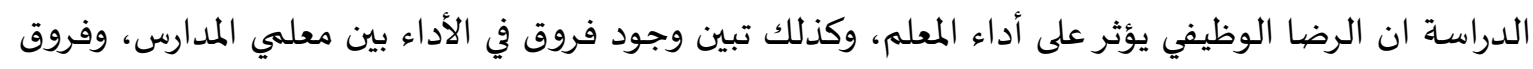

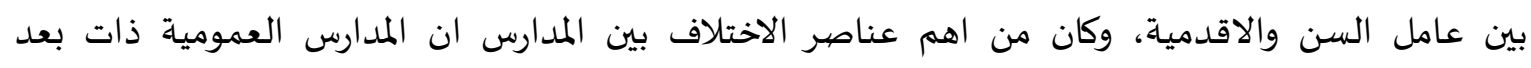

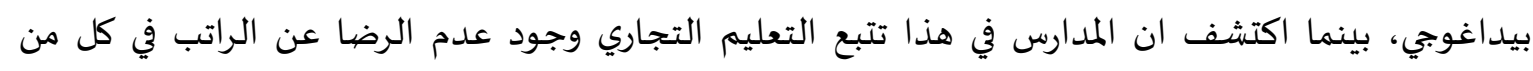

المدارس العمومية والخاصية. أما دراسة بن زوه (2017) فهدفت إلى معرفة ما درجة ممارسة مديري المدارس الابتدائية لأساليب إدارة التغيير

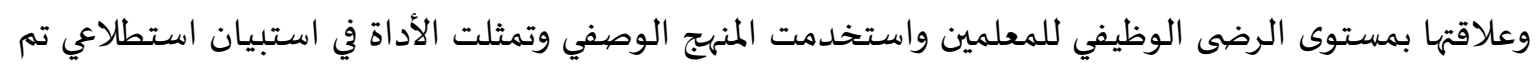

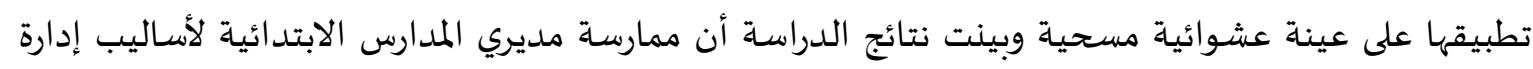

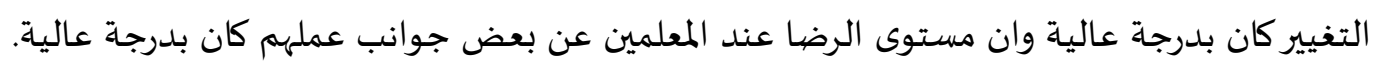

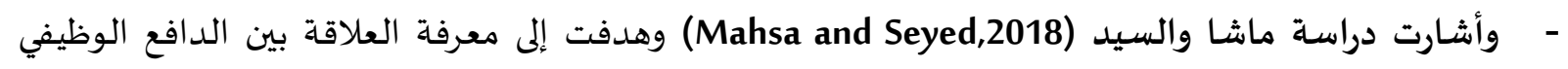

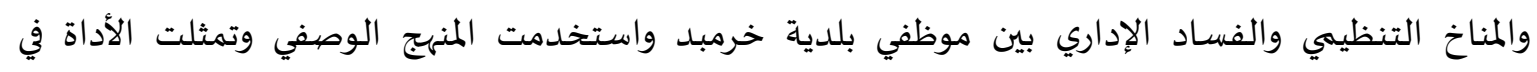

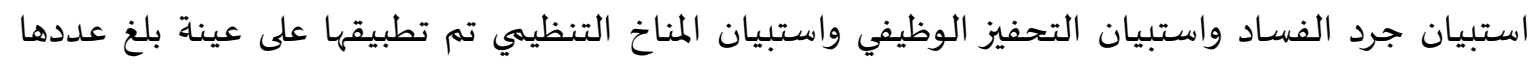

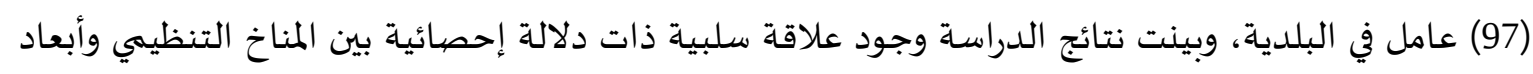

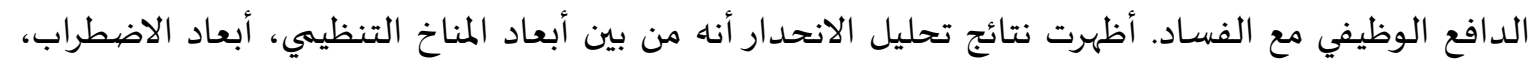

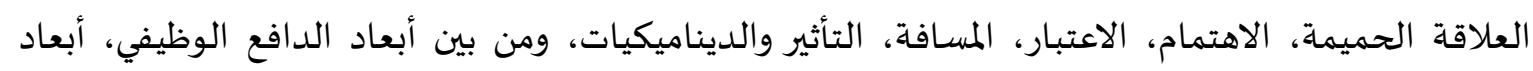

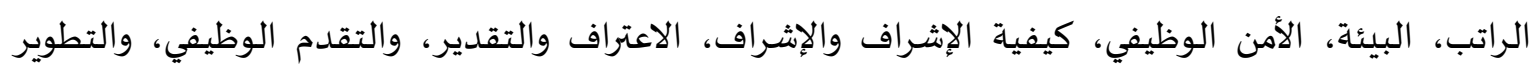
الوظيفي، والمسؤوليات الوظيفية، والمناصب الوظيفية من المؤشرات السلبية الهامة على الفساد الإداري.

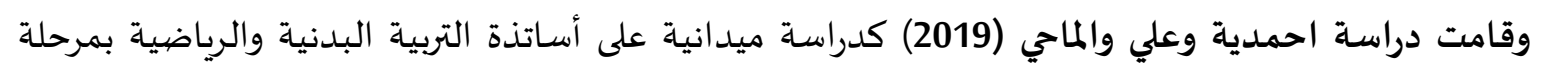

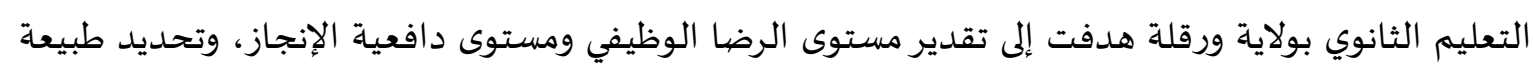

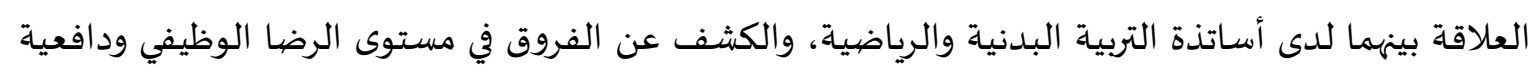

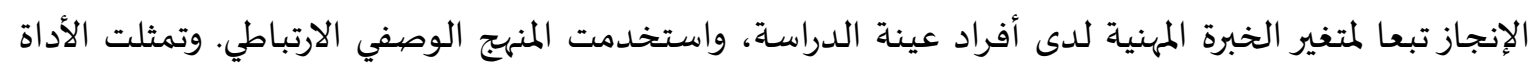

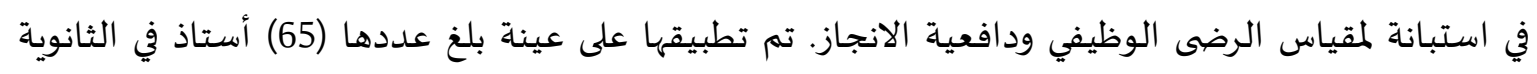

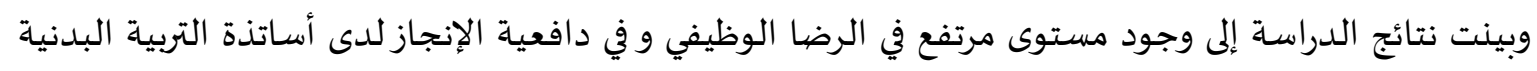


والرياضية، ولا توجد فروق ذات دلالة إحصائية في مستوى الرضا الوظيفي و في إحصائية بين مستوى الرضا

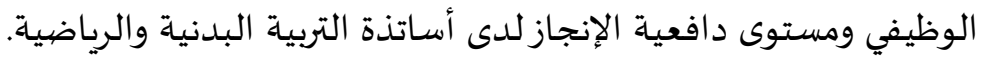

التعقيب على الدراسـات السابقة: بعد الاطلاع على الدراسات السابقة اتضح ان ظاهرة الفساد الإداري موجودة في المدارس لكنها تتباين من

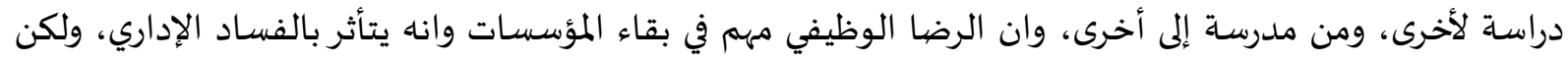

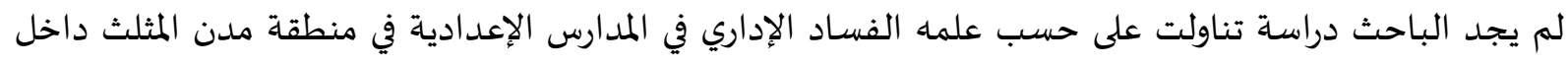
الخط الأخضر وعلاقته بالرضا الوظيفي لدى المعلمين والمرشدين من وجها لماتئ نظرهم.

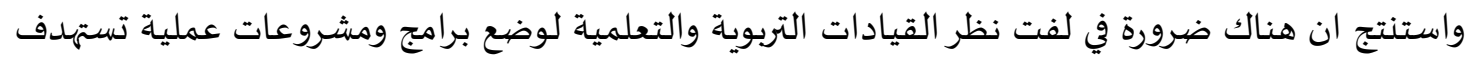

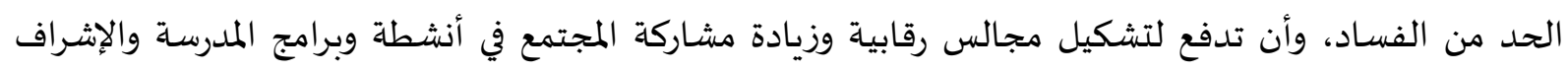
عليها، بما يحد من الفساد.

\section{- - - استخدمت الدراسات السابقة الاستبانة كأداة لتحقيق أهدافها.}

- - م- استفادت الدراسة الحالية من الدراسات السابقة في المنهجية وتطوير الأداء. ومناقشة النتائج.

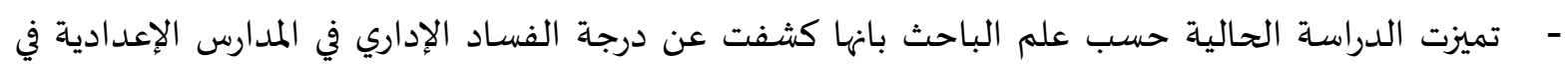

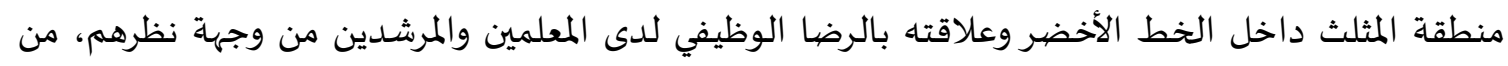
خلال أداة الدراسة التي تم تطويرها لغايات هذه الدراسة.

3- منهجية الدراسـة وإجراءاتها. منهج الدراسة: دقيقا.

مجتمع الدراسة وعينتها: تكون مجتمع الدراسة حسب إحصائيات وزارة التربية والتعليم خلال العام الدراسي (2019- 2020) من

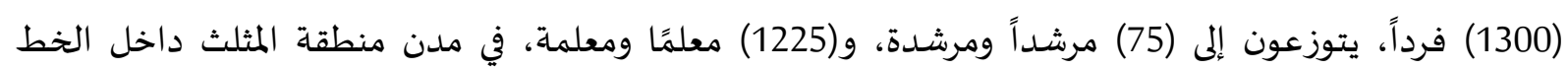

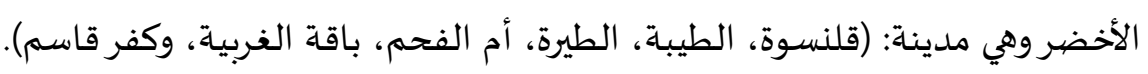

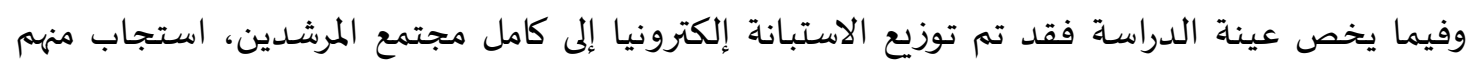
(72) فرداً بما نسبته (96\%) من مجتمعهه، كما تم توزيع (400) استبانة إلكترونيا إلى مجتمع المعلمين بالطريقة

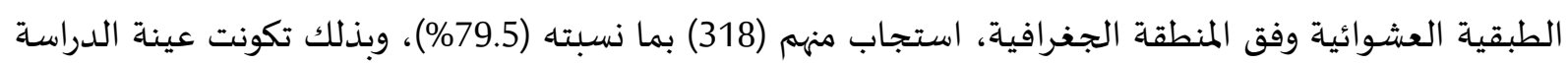

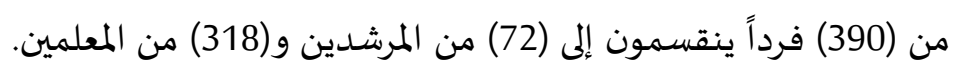

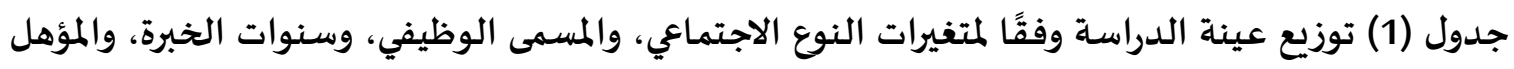
العلمي، ونوع المدرسـة.

\begin{tabular}{|c|c|c|c|c|c|c|c|}
\hline النسبة المئوية & العدد & الفئات & المتغير & المئوبة & العدد & الفئات & المتغير \\
\hline 43.3 & 169 & بكالوريوس & المؤهل & 33.3 & 130 & ذكر & النوع \\
\hline 56.7 & 221 & ماجستير & العلمي & 66.7 & 260 & أنثى & الاجتماعي \\
\hline
\end{tabular}




\begin{tabular}{|c|c|c|c|c|c|c|c|}
\hline النسبة المئوية & العدد & الفئات & المتغير & المئوية & العدد & الفئات & المتفير \\
\hline 12.1 & 47 & خاصة & \multirow{2}{*}{ نوع المدرسـة } & 18.5 & 72 & مرشد & \multirow{2}{*}{ المسيفى } \\
\hline \multirow[t]{4}{*}{87.9} & 343 & حكومية & & 81.5 & 318 & معلم & \\
\hline & 390 & & الكلي & 15.9 & 62 & سنوات من 5 & \multirow{3}{*}{ الخبرة } \\
\hline & & & & 22.3 & 87 & سين 5- 10 & \\
\hline & & & & 61.8 & 241 & أكثر من 10 & \\
\hline
\end{tabular}

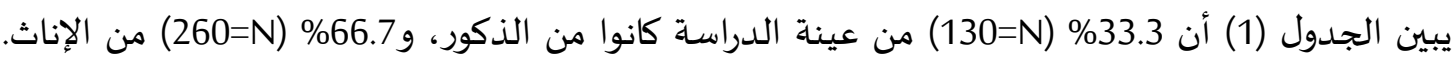

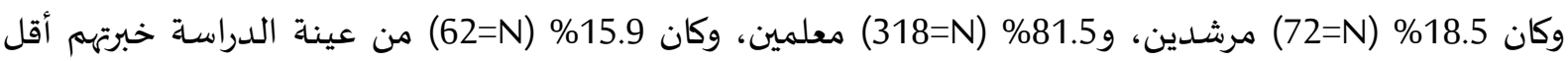

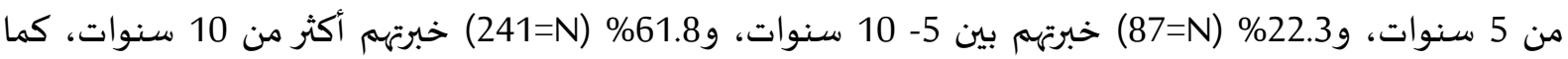

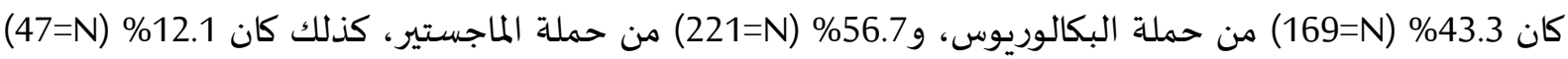
من المدارس الخاصة، و87.9\% (N43=N) من المدارس الحكومية.

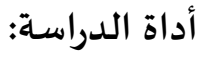

لأغراض تحقيق أهداف الدراسة، تم تطوير أداتين للدراسـة، وذلك على النحو الآتي:

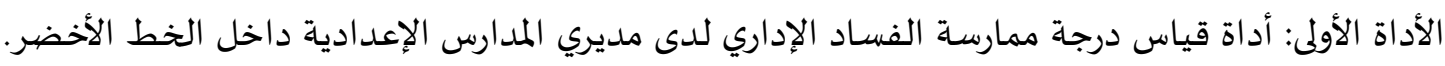

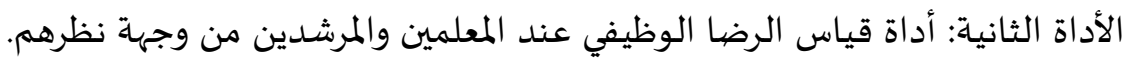

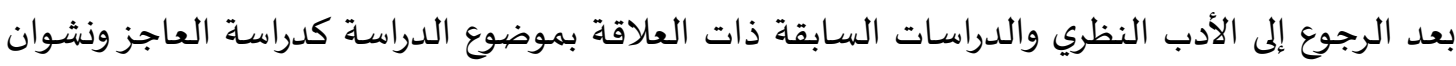

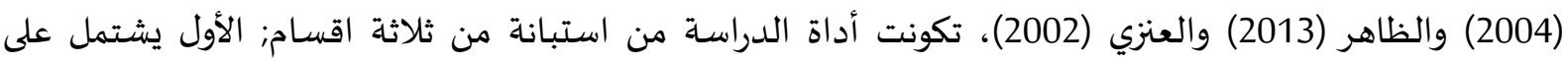
البيانات الشخصية ومتغيرات الدراسة المستقلة، والثاني تضمن مقياس درجة ممارسة الفساد الإداري لدى مدادي مديري

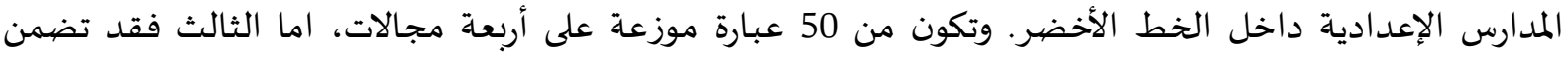

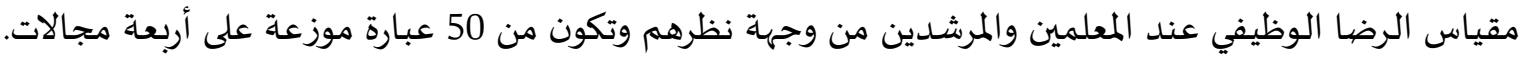

صددق أداة الدراسة (الاستبانة) وثباتها

الصدق الظاهري:

تم التحقق من الصدل الظاهري لأداة قياس درجة ممارسـة الفساد الإداري لدى مديري المدارس الإعدادية

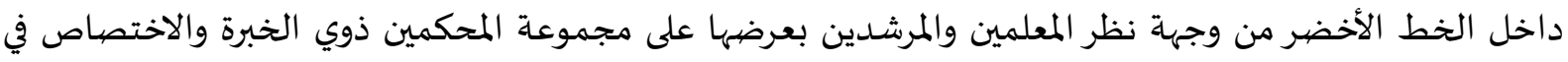

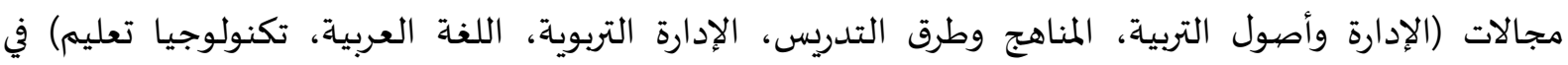

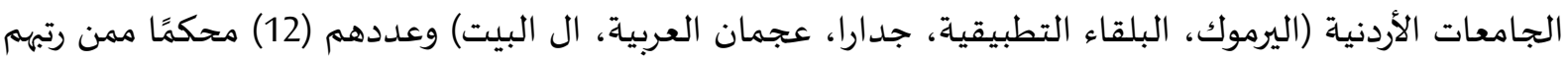

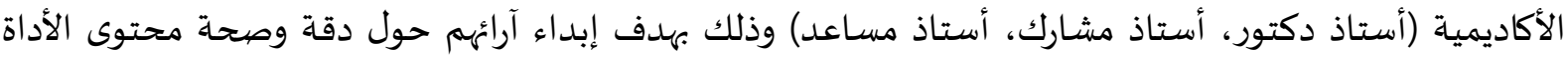

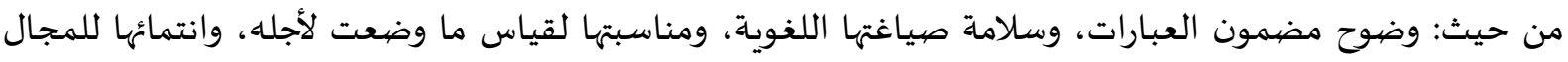

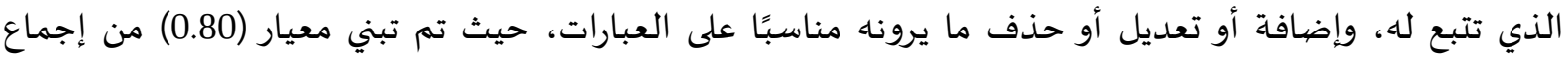

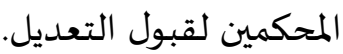


الصددق البنائي:

للتحقق من صددق البناء للأداة، فقد تم تطبيقها على عينة استطلاعية مؤلفة من (45) معلمًا ومعلماة، وتم استثناؤهم من عينة الدراسة، وذلك لحساب معاملات الارتباط لعلاقة العبارات بمجالاتها (ر1)، ومعاملات الارتباط

المصحح لعلاقة العبارات بالأداة ككل (ر2).

جدول (2) معاملات الارتباط بين درجة العبارة والدرجة الكلية لمجالها (ر1) لأداة قياس درجة الفساد الإداري لدى مديري المدارس الإعدادية داخل الخط الأخضر

\begin{tabular}{|c|c|c|c|c|c|c|c|}
\hline 2 , & 1 , & العبارة & المتغير & 2 , & 1) & العبارة & المتغير \\
\hline 0.64 & $0.71^{* *}$ & 25 & \multirow{13}{*}{ المعاملات } & 0.51 & $0.59^{* *}$ & 1 & \multirow{11}{*}{ الفسـاد المادي } \\
\hline 0.60 & $0.68^{* *}$ & 26 & & 0.77 & $0.81^{* *}$ & 2 & \\
\hline 0.52 & $0.59^{* *}$ & 27 & & 0.83 & $0.86^{* *}$ & 3 & \\
\hline 0.56 & $0.63^{* *}$ & 28 & & 0.80 & $0.84^{* *}$ & 4 & \\
\hline 0.42 & $0.51^{* *}$ & 29 & & 0.86 & $0.89^{* *}$ & 5 & \\
\hline 0.62 & $0.70^{* *}$ & 30 & & 0.88 & $0.90^{* *}$ & 6 & \\
\hline 0.56 & $0.64^{* *}$ & 31 & & 0.53 & $0.61^{* *}$ & 7 & \\
\hline 0.50 & $0.59^{* *}$ & 32 & & 0.83 & $0.86^{* *}$ & 8 & \\
\hline 0.65 & $0.72^{* *}$ & 33 & & 0.81 & $0.85^{* *}$ & 9 & \\
\hline 0.50 & $0.59^{* *}$ & 34 & & 0.84 & $0.88^{* *}$ & 10 & \\
\hline 0.68 & $0.75^{* *}$ & 35 & & 0.81 & $0.85^{* *}$ & 11 & \\
\hline 0.72 & $0.77^{* *}$ & 36 & & 0.81 & $0.84^{* *}$ & 12 & \multirow{15}{*}{ الموظفين } \\
\hline 0.58 & $0.66^{* *}$ & 37 & & 0.74 & $0.79^{* *}$ & 13 & \\
\hline 0.62 & $0.70^{* *}$ & 38 & \multirow{13}{*}{ المرافق } & 0.78 & $0.82^{* *}$ & 14 & \\
\hline 0.68 & $0.74^{* *}$ & 39 & & 0.79 & $0.83^{* *}$ & 15 & \\
\hline 0.72 & $0.78^{* *}$ & 40 & & 0.82 & $0.85^{* *}$ & 16 & \\
\hline 0.67 & $0.74^{* *}$ & 41 & & 0.41 & $0.44^{* *}$ & 17 & \\
\hline 0.46 & $0.55^{* *}$ & 42 & & 0.66 & $0.72^{* *}$ & 18 & \\
\hline 0.36 & $0.48^{* *}$ & 43 & & 0.78 & $0.81^{* *}$ & 19 & \\
\hline 0.41 & $0.35^{* *}$ & 44 & & 0.74 & $0.79^{* *}$ & 20 & \\
\hline 0.35 & $0.46^{* *}$ & 45 & & 0.45 & $0.54^{* *}$ & 21 & \\
\hline 0.59 & $0.67^{* *}$ & 46 & & 0.70 & $0.75^{* *}$ & 22 & \\
\hline 0.51 & $0.60^{* *}$ & 47 & & 0.68 & $0.73^{* *}$ & 23 & \\
\hline 0.58 & $0.67^{* *}$ & 48 & & 0.84 & $0.87^{* *}$ & 24 & \\
\hline 0.55 & $0.64^{* *}$ & 49 & & & & & \\
\hline 0.54 & $0.63^{* *}$ & 50 & & & & & \\
\hline
\end{tabular}

واستخدم معامل الارتباط (بيرسون ر1) بين درجة العبارة والدرجة الكلية لمجالها قد تراوحت بين (0.59)

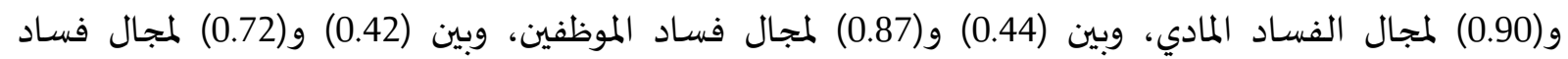

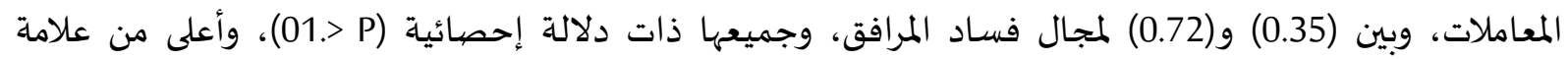
القطع (0.35)، وهذا يشير إلى صدق بناء الأداة. 
لأغراض حساب ثبات الاتساق الداخلي لأداة قياس درجة ممارسة المهارات القيادية لدى مديري المدارس

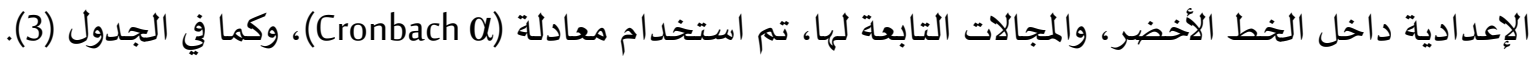

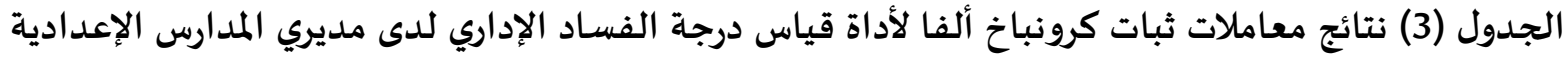
داخل الخط الأخضر

\begin{tabular}{|c|c|c|}
\hline ألفا كرونباخ & الأبعاد & المتغير \\
\hline 0.95 & المادي & \multirow{4}{*}{ الفساد الإداري } \\
\hline 0.93 & الموظفين & \\
\hline 0.89 & المعاملات & \\
\hline 0.85 & المرافق & \\
\hline 0.97 & \multicolumn{2}{|c|}{ الكلي } \\
\hline
\end{tabular}

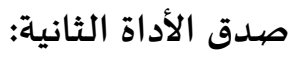
جدول 4: معاملات الارتباط بين درجة العبارة والدرجة الكلية لمجالها (ر1) لأداة قياس مستوى الرضيا الوظيفي

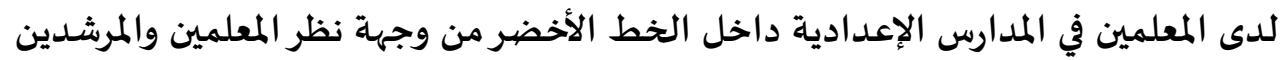

\begin{tabular}{|c|c|c|c|c|c|c|c|}
\hline 2, & 1 & العبارة & المتفير & 2, & 1, & العبارة & المتغير \\
\hline 0.43 & $0.44^{* *}$ & 27 & \multirow{12}{*}{ المدرسية البيئة } & 0.52 & $0.61^{* *}$ & 1 & \multirow{12}{*}{ القيادة } \\
\hline 0.44 & $0.43^{* *}$ & 28 & & 0.57 & $0.65^{* *}$ & 2 & \\
\hline 0.61 & $0.69^{* *}$ & 29 & & 0.56 & $0.64^{* *}$ & 3 & \\
\hline 0.68 & $0.75^{* *}$ & 30 & & 0.51 & $0.43^{* *}$ & 4 & \\
\hline 0.49 & $0.39^{* *}$ & 31 & & 0.84 & $0.87^{* *}$ & 5 & \\
\hline 0.75 & $0.81^{* *}$ & 32 & & 0.79 & $0.83^{* *}$ & 6 & \\
\hline 0.74 & $0.81^{* *}$ & 33 & & 0.83 & $0.87^{* *}$ & 7 & \\
\hline 0.71 & $0.78^{* *}$ & 34 & & 0.84 & $0.87^{* *}$ & 8 & \\
\hline 0.71 & $0.78^{* *}$ & 35 & & 0.53 & $0.62^{* *}$ & 9 & \\
\hline 0.48 & $0.40^{* *}$ & 36 & & 0.72 & $0.77^{* *}$ & 10 & \\
\hline 0.47 & $0.56^{* *}$ & 37 & & 0.81 & $0.85^{* *}$ & 11 & \\
\hline 0.64 & $0.73^{* *}$ & 38 & & 0.82 & $0.86^{* *}$ & 12 & \\
\hline 0.81 & $0.85^{* *}$ & 39 & \multirow{10}{*}{ والتدريب } & 0.72 & $0.79^{* *}$ & 13 & \multirow{10}{*}{ الممادي } \\
\hline 0.82 & $0.86^{* *}$ & 40 & & 0.75 & $0.81^{* *}$ & 14 & \\
\hline 0.81 & $0.84^{* *}$ & 41 & & 0.62 & $0.70^{* *}$ & 15 & \\
\hline 0.81 & $0.85^{* *}$ & 42 & & 0.46 & $0.38^{* *}$ & 16 & \\
\hline 0.79 & $0.83^{* *}$ & 43 & & 0.47 & $0.47^{* *}$ & 17 & \\
\hline 0.84 & $0.87^{* *}$ & 44 & & 0.52 & $0.61^{* *}$ & 18 & \\
\hline 0.85 & $0.87^{* *}$ & 45 & & 0.60 & $0.70^{* *}$ & 19 & \\
\hline 0.85 & $0.87^{* *}$ & 46 & & 0.69 & $0.76^{* *}$ & 20 & \\
\hline 0.84 & $0.86^{* *}$ & 47 & & 0.55 & $0.65^{* *}$ & 21 & \\
\hline 0.79 & $0.83^{* *}$ & 48 & & 0.56 & $0.65^{* *}$ & 22 & \\
\hline
\end{tabular}




\begin{tabular}{|c|c|c|c|c|c|c|c|}
\hline 2, & 1 & العبارة & المتغير & 2, & 1 & العبارة & المتغير \\
\hline 0.84 & $0.84^{* *}$ & 49 & & 0.46 & $0.39^{* *}$ & 23 & \\
\hline \multirow[t]{3}{*}{0.44} & $0.47^{* *}$ & 50 & & 0.48 & $0.45^{* *}$ & 24 & \\
\hline & & & & 0.47 & $0.42^{* *}$ & 25 & \\
\hline & & & & 0.42 & $0.35^{* *}$ & 26 & \\
\hline
\end{tabular}

كما يتضح من الجدول (4)، تراوحت معاملات الارتباط بين درجة العبارة والدرجة الكلية لمجالها بين (0.43)

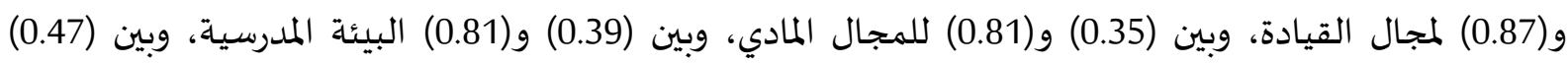

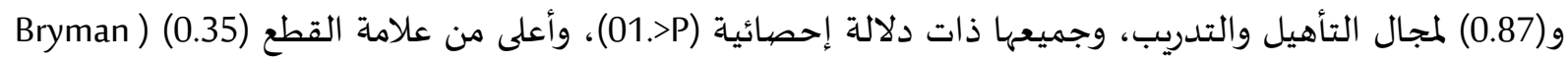

(Cramer

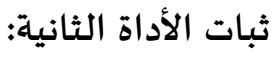

لأغراض حساب ثبات الاتساق الداخلي لأداة قياس مستوى الرضا الوظيفي لدى المعلمين في المدارس المانس

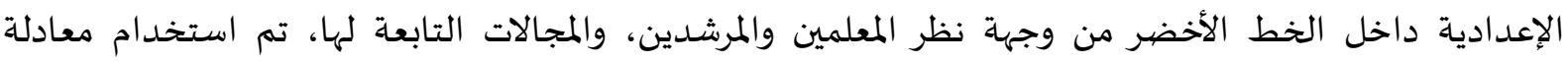

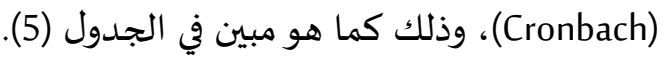

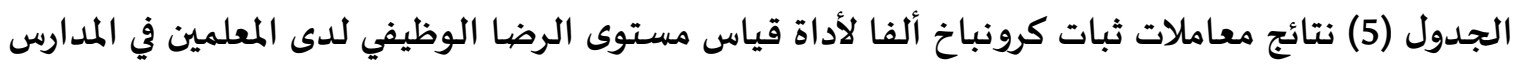
الإعدادية داخل الخط الأخضر من وجهة نظر المعلمين والمرشدين

\begin{tabular}{|c|c|c|}
\hline ألفا كرونباخ & الأبعاد & المتفير \\
\hline 0,89 & القيادة & \multirow{5}{*}{ الرضا الوظيفي } \\
\hline 0.79 & المادي & \\
\hline 0.86 & البيئة المدرسية & \\
\hline 0.95 & التأهيل والتدريب & \\
\hline 0.94 & الكلي & \\
\hline
\end{tabular}

للإجابة على عبارات أداتي الدراسة تم استخدام تدريج ليكرت الذي يشتمل على خمسة بدائل، هي: كبيرة جدًا وتعطى عند تصحيح العبارة درجة قيمتها (5)، كبيرة وتعطى عند تصحيح العبارة درجة قيمتها (4)، متوسطة وتعطى عند تصحيح العبارة درجة قيمتها (3)، قليلة وتعطى عند تصحيح العبارة درجة قيمتها (2)، قليلة جدًا وتعطى دئل

عند تصحيح العبارة درجة قيمتها (1).

ولأغراض تقييم استجابات أفراد عينة الدراسـة، تمَّ تصنيف المتوسطات الحسابية لاستجابات أفرات أفراد عينة

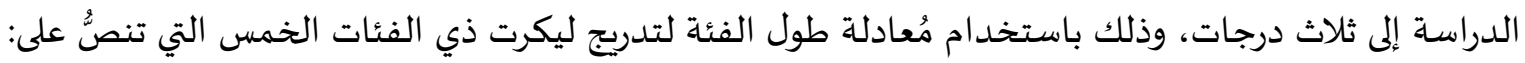

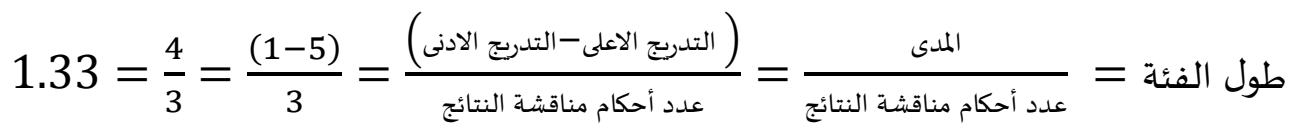
وعليه، فقد تم تقييم استجابات أفراد عينة الدراسة على النحو الآتي:

\begin{tabular}{|c|c|}
\hline الدرجة/المستوى & القيمة \\
\hline قليلة & $1.00-2.33$ \\
\hline متوسطة & $2.34-3.67$ \\
\hline كبيرة & 3.68- 5 \\
\hline
\end{tabular}


المعالجات الإحصائية:

تمَّت المعالجات الإحصائية لبيانات الدراسة باستخدام الرزمة الإحصائية للعلوم الاجتماعية (SPSS)، وذلك

على النحو الآتي:

- ل للإجابة على أسئلة الدراسة تمَّ حساب المتوسطات الحسابية والانحرافات المعيارية، مع مراعاة ترتيب المجالات

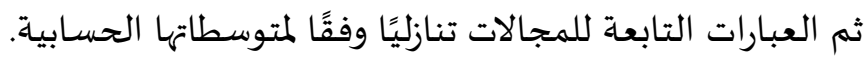

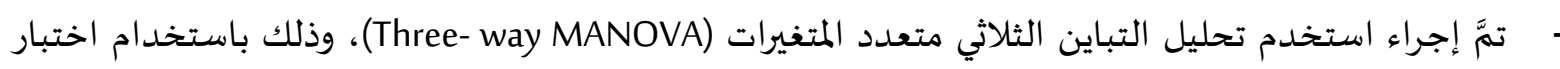

.(Hotelling's Trace)

- تم حساب معاملات ارتباط بيرسون لتوضيح العلاقات.

4- عرض النتائج ومناقشتها.

النتائج المتعلقة بالسؤال الأول: ما درجة ممارسة الفساد الإداري لدى مديري المدارس الإعدادية داخل

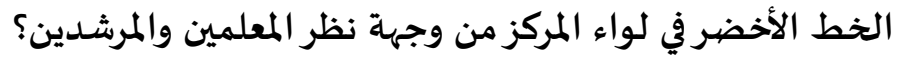

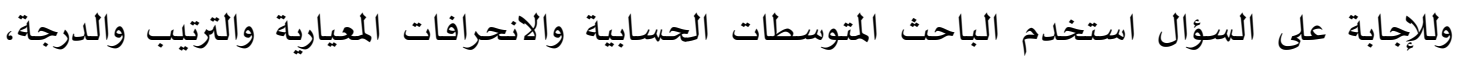

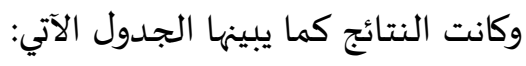

الجدول (6) المتوسطات الحسابية والانحرافات المعيارية والدرجة، لتقديرات عينة الدراسة لدرات لدرجة ممارسة

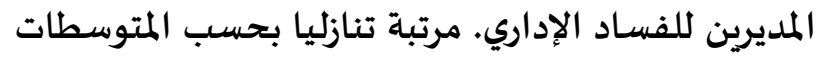

\begin{tabular}{|c|c|c|c|c|c|}
\hline درجة الممارسة & الترتيب & الانحراف المعياري & المتوسط الحسابي & مستويات المتغير التابع & $\hat{\imath}$ \\
\hline كبيرة & 1 & .94 & 3.75 & الموظفين & 1 \\
\hline متوسطة & 2 & .88 & 3.31 & المادي & 2 \\
\hline متوسطة & 3 & .69 & 3.17 & المعاملات & 3 \\
\hline متوسطة & 4 & .64 & 3.05 & المرافق & 4 \\
\hline متوسطة & & 0.69 & 3.25 & 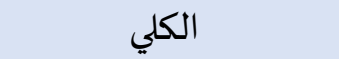 & \\
\hline
\end{tabular}

يتبين من الجدول (6)،.أن ممارسة الفساد الإداري لدى مديري المدارس الإعدادية بدرجة ممارسة كبيرة، أذ أذ

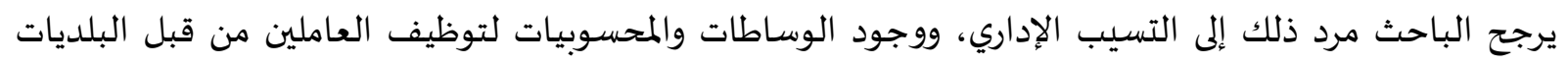

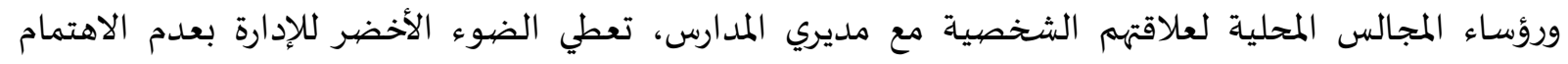

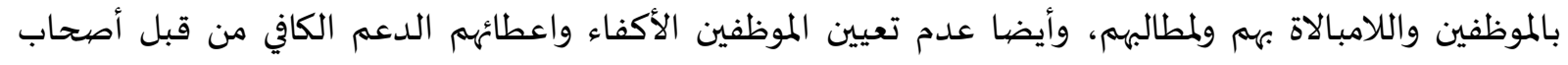

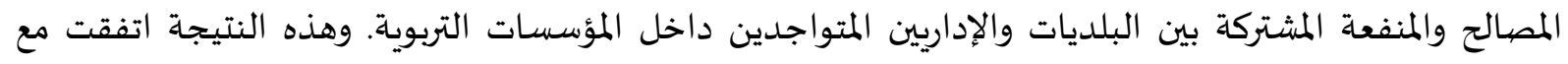

دراسة (Mahsa and Seyed,2018)

وعلى مستوى المجالات الأربعة للفساد الإداري فقد كانت على النحو الآتي:

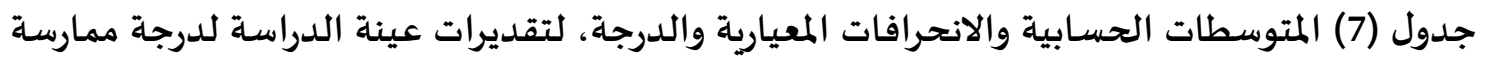

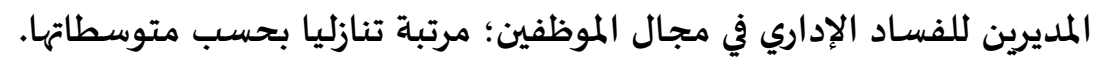

\begin{tabular}{|c|c|c|c|c|c|}
\hline الفساد & 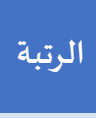 & المعياري & المستوسطي & 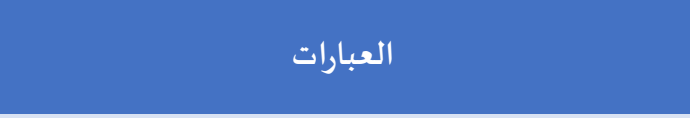 & $\hat{\imath}$ \\
\hline كبيرة & 1 & 0.95 & 3.81 & توجد جماعات في المدرسة تؤثر سلباً في اتخاذ القرارات. & 22 \\
\hline
\end{tabular}


المجلة العربية للطوم ونشر الأبحاث ـ مجلة العلوم التربوية والنفسية ـ المجلد الخامس ـ العدد السابع والأربعون ـ ديسمبر 2021م

\begin{tabular}{|c|c|c|c|c|c|}
\hline الفساد & 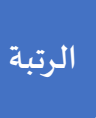 & 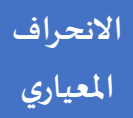 & المتوسط المسابي & 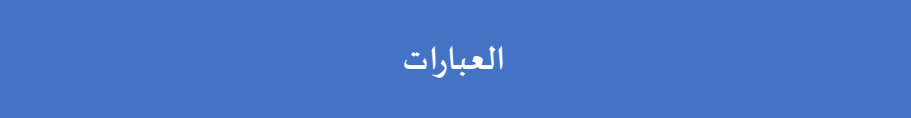 & $\hat{\imath}$ \\
\hline كبيرة & 2 & 1.11 & 3.74 & ان التعيينات للمعلمين تحكمها العلاقات الشخصية من قِبل الإداريبن. & 15 \\
\hline كبيرة & 3 & 1.13 & 3.67 & الإداري يهتم بمصبالحه الشخصية والعائلية وذلك من خلال توظيف & 16 \\
\hline 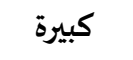 & 4 & 1.01 & 3.62 & يتم حرمان فرص العمل والتوظيف لأصحاب الكفاءة. & 20 \\
\hline كبيرة & 5 & 1.04 & 3.58 & لا توجد أداة لردع الموظفين الفاسدين من قبل المؤسسات التربوية & 23 \\
\hline كبيرة & 6 & 1.07 & 3.54 & تتكون طبقة من الإداريين داخل المؤسسة التربوية تفُضل المصالح & 13 \\
\hline 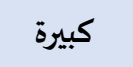 & 7 & 0.98 & 3.40 & توجد تحيزات لجانب واحد فقط في المؤسسات التربوية. & 19 \\
\hline كبيرة & 8 & 1.10 & 3.44 & الإدارة تستغل مكانتها لتحقيق مأّرب شخصية على حساب المؤسسة & 24 \\
\hline متوسطة & 9 & 1.18 & 3.38 & يتم التعدي على حقوق المعلمين والمرشدين من قِبل الإدارة. & 12 \\
\hline 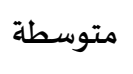 & 10 & 1.18 & 3.35 & يتم تعيين الموظف المناسب في المكان المناسب. & 21 \\
\hline 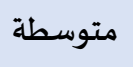 & 11 & 1.19 & 3.18 & الترقية داخل المؤسسات التربوية تكون فقط حسب الكفاءات. & 17 \\
\hline 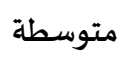 & 12 & 1.14 & 3.16 & يتم استغلال قدرات المعلمين والمرشدين من قِبل الإدارة بشكل غير قانوني. & 14 \\
\hline 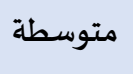 & 13 & 1.07 & 3.11 & يتم مضايقة وإزعاج المعلمين خارج المؤسسات التربوية. & 18 \\
\hline 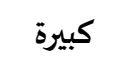 & & 0.94 & 3.75 & 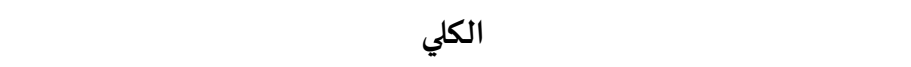 & \\
\hline
\end{tabular}

يتبين من الجدول (7) ان مجال الموظفين جاء في المرتبة الأولى، حيث تراوحت المتوسطات الحسابية

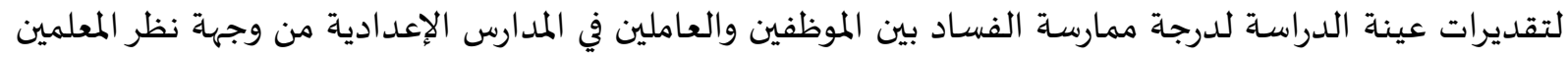
والمرشدين بدرجة ممارسة من متوسطة إلى كبيرة، فقد تبين تواجد جماعات في المدرسة تؤثر سلبا في اتخاذ القرارات

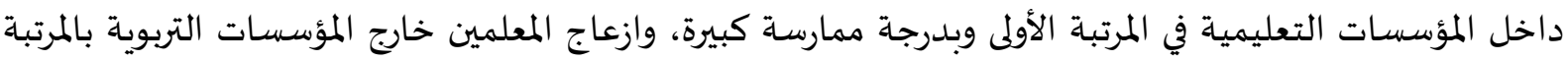
الأخيرة وبدرجة ممارسة متوسطة.

بحيث تبين لنا أن ممارسة الفساد الإداري بين الموظفين لدى مدئوسي مداري المدارس الإعدادية بدرجة ممارسة

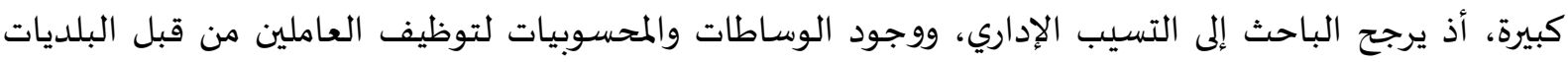

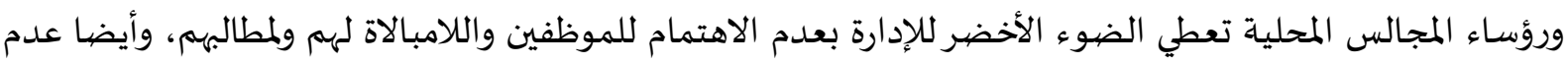
تعيين الموظفين الأكفاء واعطائهم الدعم الكافي من قبل أصحاب المصالح والمنفعة المشتركة بين البلديات والإداريين

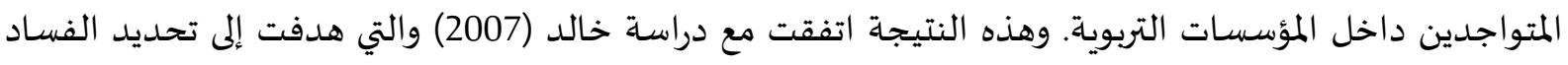
واستغلال استعمال السلطة الوظيفية. 
جدول (8) المتوسطات الحسابية والانحرافات المعيارية والدرجة، لتقديرات عينة الدراسة لدرجة ممارسة المديرين للفساد الإداري في مجال المادي؛ مرتبة تنازليا بحسب متوسطاتها.

\begin{tabular}{|c|c|c|c|c|c|}
\hline الفساد & 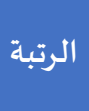 & 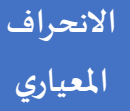 & المستوسط الحسبي & 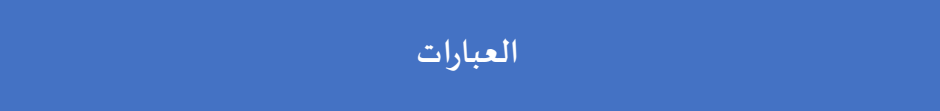 & $\hat{\imath}$ \\
\hline 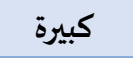 & 1 & 1.14 & 3.80 & قبول الهدايا من قبل الإداري يؤثر على نزاهة المؤسسة التربوية. & 7 \\
\hline 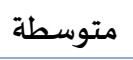 & 2 & 1.04 & 3.39 & يتجاوز الإداري الانظمة واللوائح بالمؤسسة التربوية. & 2 \\
\hline 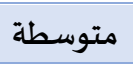 & 3 & 1.04 & 3.37 & يتقاضى الإداري مبالغ مادية مقابل إنجاز أعمال نظامية. & 1 \\
\hline 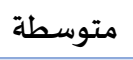 & 4 & 1.25 & 3.30 & يتم توظيف معلمين مقابل مصالح مادية. & 4 \\
\hline 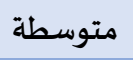 & 5 & 1.17 & 3.28 & يستغل الإداريين اموال المؤسسة التربوية للمصالح المختلفة. & 3 \\
\hline 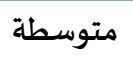 & 5 & 1.21 & 3.28 & يقوم الإداريين بابتزازوظيفة المعلمين والمرشدين. & 9 \\
\hline متوسطة & 7 & 1.16 & 3.23 & تتم سرقة أو نهب المال العام داخل المؤسسات التربوية. & 8 \\
\hline 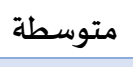 & 8 & 1.13 & 3.22 & يتجاوز المدير الأنظمة المالية والإدارية داخل المؤسسة التربوية. & 5 \\
\hline 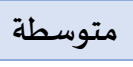 & 9 & 1.19 & 3.19 & يتلاعب الإداريين المستندات والتواقيع للحصهول على منافع ذاتية. & 10 \\
\hline 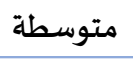 & 10 & 1.17 & 3.17 & يتبادل الإداري المصالح للحصول على منافع مالية غير مُستحقة. & 6 \\
\hline 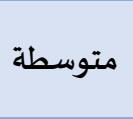 & 11 & 1.16 & 3.14 & يوجد استغلال وكشف المعلومات الداخلية داخل المؤسسات التربوية مقابل & 11 \\
\hline 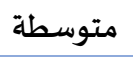 & & 0.88 & 3.31 & 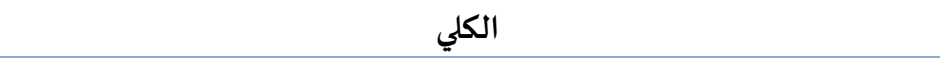 & \\
\hline
\end{tabular}

يتبين من الجدول (8) أن المجال المادي جاء في المرتبة الثانية، بدرجة ممارسة من متوسطة إلى كبيرة كما،

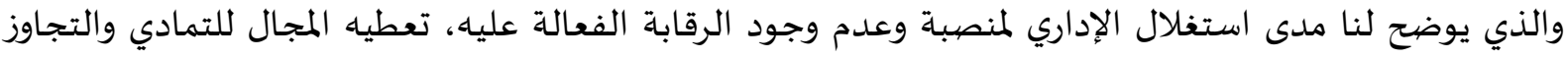

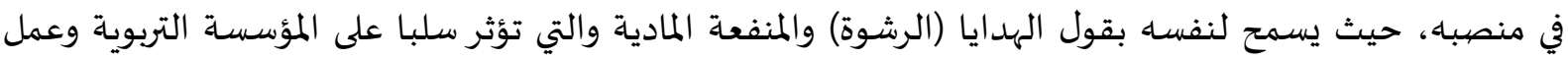
الإداري، طبعا مقابل خدمات مختلفة لبعض المنتفعين على حساب المؤسسات التربوية والخدمات الطلابية. وهذه النتيجة اتفقت مع نتائج دراسة الظاهر (2013) وكذلك محمد وداود (2011) والتي تبين الفساد المادي وأثارة على مجادي

جدول (9) المتوسطات الحسابية والانحرافات المعيارية والدرجة، لتقديرات عينة الدراسـة لدرجة ممارسة المديرين للفساد الإداري في مجال المعاملات؛ مرتبة تنازليا بحسب متوسطاتها.

\begin{tabular}{|c|c|c|c|c|c|}
\hline 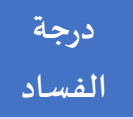 & 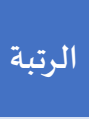 & 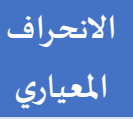 & المتوسط المسابي & 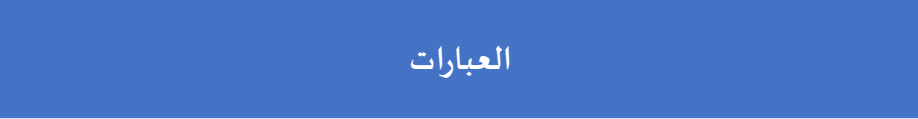 & $\hat{\imath}$ \\
\hline كبيرة & 1 & 1.05 & 3.54 & يوجد تَّسيب وإهمال وظيفي ولامبالاة داخل المؤسسات التربوية. & 25 \\
\hline كبيرة & 2 & 1.04 & 3.53 & غياب المشاركة الديموقراطية بين الادارة والمعلمين والمرشدين في المؤسسات & 31 \\
\hline كبيرة & 3 & 0.93 & 3.45 & التباطؤ في انجاز المعاملات المختلفة في المؤسسات التربوية. & 28 \\
\hline كبيرة & 4 & 1.05 & 3.44 & وجود الإداري لوقت طويل يؤثر سلباً على علاقته بين المعلمين والمرشدين. & 29 \\
\hline كبيرة & 4 & 1.10 & 3.44 & يوجد عدل في التعامل بين جميع العاملين داخل المؤسسات التربوية & 37 \\
\hline كبيرة & 6 & 0.91 & 3.42 & تراجع المعاملات بين الإدارة وبين المعلمين والمرشدين & 27 \\
\hline متوسطة & 7 & 1.09 & 3.18 & تعتمد المعاملات على المصالح الشخصية فقط. & 34 \\
\hline 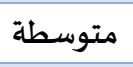 & 8 & 1.16 & 3.14 & توجد شفافية ومصارحة بين المعلمين داخل المؤسسات التربوية. & 30 \\
\hline 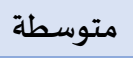 & 9 & 1.08 & 3.08 & عند المعلمين والمرشدين ثقة كبيرة بالإدارة الموجودة بالمؤسسات التربوية & 36 \\
\hline 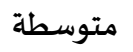 & 10 & 1.07 & 2.88 & يوجد رقابة داخلية وخارجية في المؤسسات التربوية. & 26 \\
\hline
\end{tabular}




\begin{tabular}{|c|c|c|c|c|c|}
\hline الفساد & 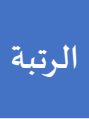 & الانحراف & المتوسط الحسابي & العبارات & $\hat{r}$ \\
\hline كبيرة & 11 & 1.08 & 2.88 & يهتم الإداري بالكفاءات وجدارة المعلمين والمرشدين. & 35 \\
\hline 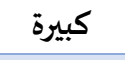 & 12 & 1.05 & 2.73 & يوجد انتماء من قبل المعلمين والمرشدين للمؤسسـات التربوية. & 33 \\
\hline كبيرة & 13 & 1.03 & 2.52 & احترام أوقات ومواعيد الدوام. & 32 \\
\hline متوسطة & & 0.69 & 3.17 & الكلي & \\
\hline
\end{tabular}

يتبين من الجدول (9) أن مجال المعاملات جاء في المرتبة الثالثة بمتوسط حسابي وبدرجة متوسطة، حيث

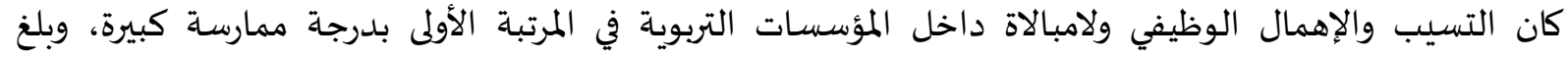

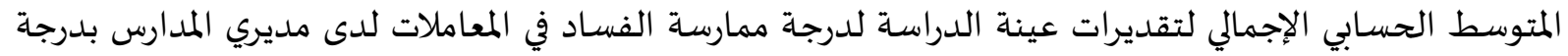
ممارسة متوسطة. حيث يعزو الباحث بان سوء المعاملات داخل المؤسسة التربوية يقتصر بإعطاء المهام لأشخاص غير المهاي مهنيين ولا يتمتعون بمهارات التعامل مع الاخرين في المؤسسات التربوية. وهذه النتيجة اتفقت إلى حد معين مع دراسـة صلاح الدين (2001) التي تركز على أهمية التعامل مع الموظفين.

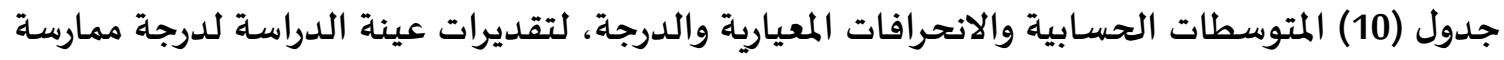

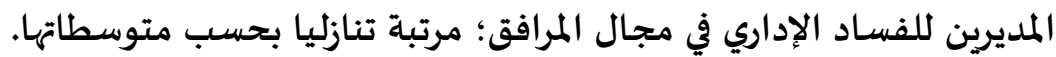

\begin{tabular}{|c|c|c|c|c|c|}
\hline درجة الفساد & الرتبة & الانحراف & المتوسط الحسابي & العبارات & $\hat{\imath}$ \\
\hline كبيرة & 1 & 1.11 & 3.52 & ضعف الرقابة على عمال الصيانة التابعين للمؤسسات التربوية. & 50 \\
\hline متوسطة & 2 & 1.17 & 3.48 & تنقُص المدرسة الادوات المدرسية بسبب سوء استخدام المرافق فيها. & 40 \\
\hline متوسطة & 3 & 1.08 & 3.30 & عدم صيانة المرافق والاجهزة المدرسية. ع & 48 \\
\hline متوسطة & 4 & 1.05 & 3.25 & تستخدم الأجهزة المدرسية لإنجاز المصهالح الشخصية للإداريين. & 38 \\
\hline متوسطة & 4 & 1.15 & 3.25 & تتلاءم الرواتب والحوافز التي يحصل عليها المعلمين مع عملهم. & 43 \\
\hline متوسطة & 6 & 1.10 & 3.17 & يتم استغلال المرافق المدرسية لمنافع وأغراض شخصية. & 39 \\
\hline متوسطة & 7 & 1.10 & 3.16 & يتم تحويل ممتلكات المدرسة إلى مصالح شخصية لبعض الاشخاص. & 41 \\
\hline متوسطة & 8 & 1.08 & 3.12 & استغلال الاموال المعطاة للمرافق المدرسية للمصالح الشخصية. & 46 \\
\hline متوسطة & 9 & 1.09 & 2.98 & يوجد تلائم بين المرافق والاجهزة المدرسية وبين حاجات الطالب. & 49 \\
\hline متوسطة & 10 & 1.03 & 2.91 & يوجد دعم مادي مستمر للمرافق والاجهزة المدرسية. & 45 \\
\hline متوسطة & 11 & 1.10 & 2.72 & مدرستي تتطور بشكل مُستمروومُواكبة للتكنولوجية بأجهزتها ومرافقها. & 47 \\
\hline متوسطة & 12 & 1.03 & 2.71 & 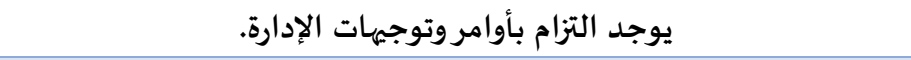 & 42 \\
\hline قليلة & 13 & 0.90 & 2.10 & تدني الكفاءة تؤدي إلى عدم استثمار الموارد المدرسية بالطريقة الصحيحـة. & 44 \\
\hline متوسطة & & 0.64 & 3.05 & 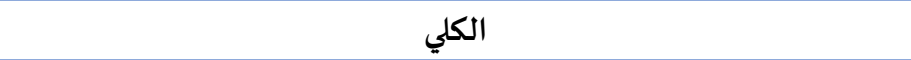 & \\
\hline
\end{tabular}

يتبين من الجدول (10) مجال المرافق في المرتبة الرابعة بمتوسط حسابي (3.05) وبدرجة متوسطة، وبدرجة ممارسة من قليلة إلى كبيرة، حيث جاء ضعف الرقابِ الردابة على عمال الصيانة التابعين للمؤسسات التربوية في المرتبة

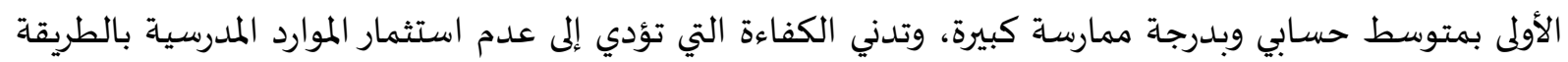

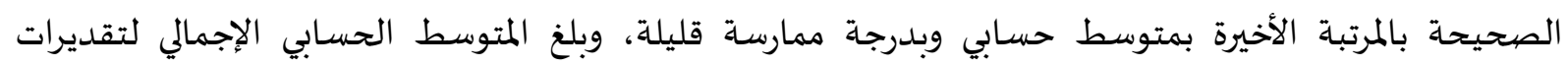

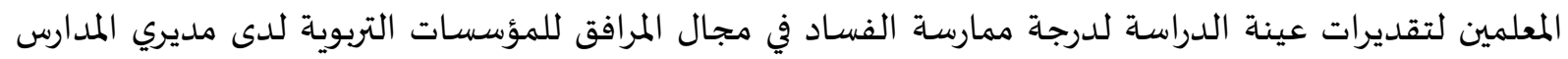

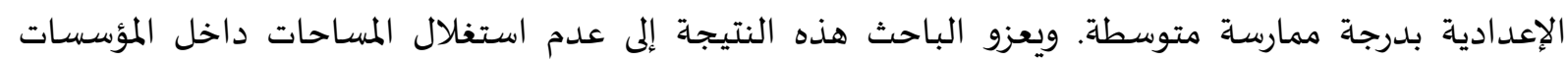

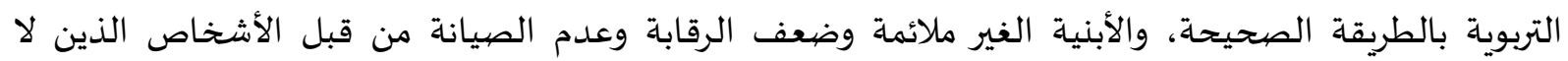

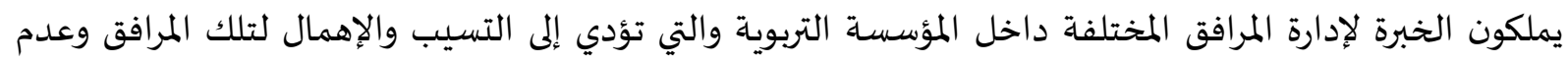


استغلالها كما يجب. وهذه النتيجة اتفقت مع نتائج دراسة فرحان (2010) والتي هدفت لتحديد أهمية الإدارة

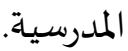

النتائج المتعلقة بالسؤال الثاني: ما مُستوى الرضا الوظيفي للمعلمين والمرشدين في المدارس الإعدادية داخل

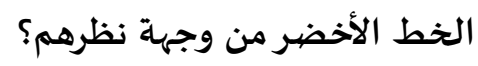

أظهرت النتائج حسب ما تبين أن المتوسطات الحسابية لتقديرات المعلمين لمجالات الرضها الوظيفي الأربعة

قد تراوحت بين درجة ممارسة من متوسطة إلى كبيرة، حيث جاءت تقديرات الرضا عن البيئة المدرسية في المرتبة

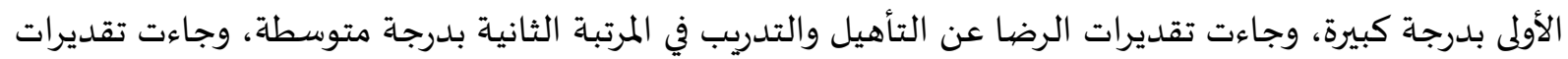

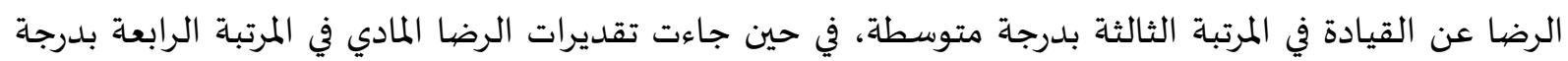

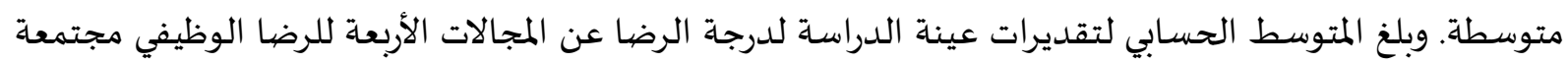

بدرجة متوسطة.

الجدول (11) المتوسطات الحسابية والانحرافات المعيارية والدرجة، لتقديرات عينة الدراسة لدرجة الرضا الوظيفي. مرتبة تنازليا بحسب المتوسطات

\begin{tabular}{|c|c|c|c|c|}
\hline درجة الرضيا & الترتيب & الانحراف المعياري & المتوسط الحسابي & مستويات المتغير \\
\hline كبيرة & 1 & 0.63 & 3.66 & البيئة المدرسية \\
\hline متوسطة & 2 & 0.70 & 3.21 & التأهيل والتدريب \\
\hline متوسطة & 3 & 0.78 & 3.04 & القيادة \\
\hline متوسطة & 4 & 0.57 & 2.94 & المادي \\
\hline متوسطة & & 0.54 & 3.27 & الكلي \\
\hline
\end{tabular}

يتبين من الجدول (11) أن المتوسطات الحسابية لتقديرات عينة الدراسة لدرجة رضاهم من القيادة

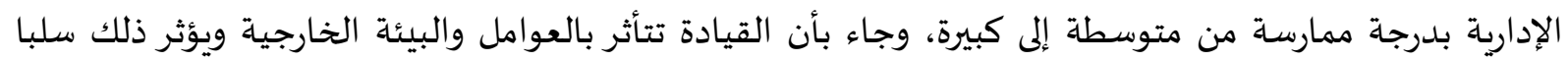

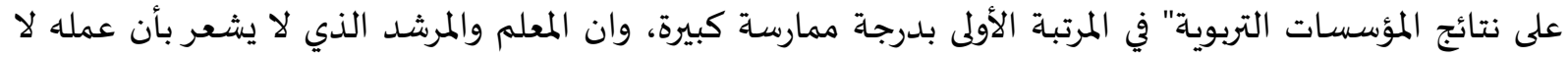

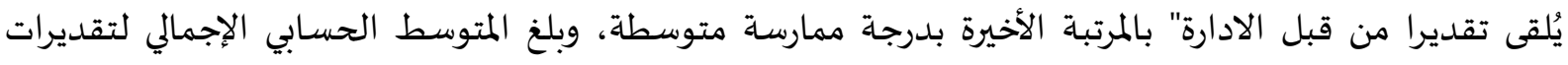

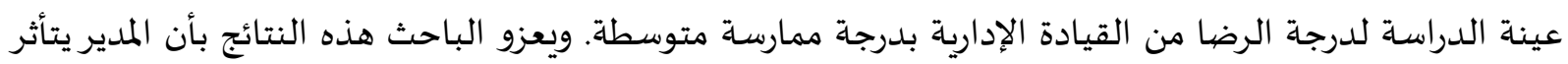

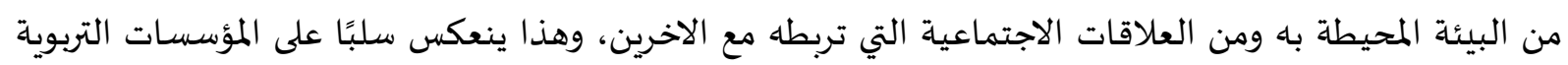

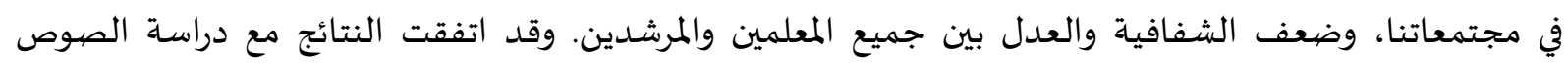

$$
\text { وعلى مستوى المجالات الأربعة للرضا كانت النتائج على النحو الآتي: }
$$

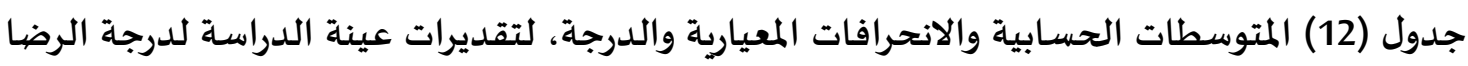
الوظيفي المتعلق بالجانب المادي ؛ مرتبة تنازليا بحسب متوسطاتهاتها.

\begin{tabular}{|c|c|c|c|c|c|}
\hline الرضها & 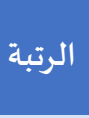 & المعياري & الحستوسطي & 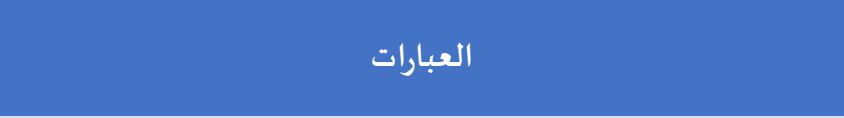 & $\hat{\imath}$ \\
\hline 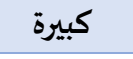 & 1 & 0.92 & 3.84 & الحوافز المدرسية تؤثر عليك بصورة إيجابية خلال وجودك بالمدرسة. & 17 \\
\hline كبيرة & 2 & 1.13 & 3.55 & يؤثر الراتب على عملك ورضاك في المدرسة. & 16 \\
\hline 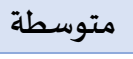 & 3 & 1.25 & 3.37 & يوجد تلاعب بعدد الساعات المدرسية للمعلمين والمرشدين & 25 \\
\hline
\end{tabular}




\begin{tabular}{|c|c|c|c|c|c|}
\hline الربة & 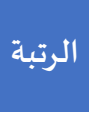 & الالمحراف & المتوسط & العبارات & $\hat{\imath}$ \\
\hline متوسطة & 4 & 1.13 & 3.00 & يوجد تأثير للإدارة على الراتب الذي اتقاضـاه من قبل وزارة التربية والتعليم & 24 \\
\hline متوسطة & 5 & 1.15 & 2.97 & المدير له تأثير على راتبي & 23 \\
\hline متوسطة & 6 & 1.03 & 2.96 & توجد أليه محددة لضمان تكافؤ الفرص لدى المعلمين والمرشدين. & 18 \\
\hline متوسطة & 7 & 1.18 & 2.94 & هناك سياسة واضحة للترقيات والحوافز. & 26 \\
\hline متوسطة & 8 & 1.14 & 2.75 & يوجد عندي شعور بالرضا الوظيفي لعدالة وشفافية قرارات الترقية من قبل & 22 \\
\hline متوسطة & 9 & 1.08 & 2.71 & الحوافز المادية التي اتقاضهها تجعلني لا أفكر في ترك مهنة التدريس. & 21 \\
\hline متوسطة & 10 & 1.24 & 2.69 & تعتبر الزيادة السنوية بالراتب مناسبة & 19 \\
\hline متوسطة & 11 & 1.14 & 2.65 & يكفيك الراتب لحياة كريمة مع أسرتك. & 15 \\
\hline متوسطة & 12 & 1.12 & 2.64 & مدى رضياك بالراتب مقارنة بمستواك ومؤهلاتك العلمية. & 20 \\
\hline متوسطة & 13 & 1.17 & 2.54 & يعتبر الراتب مناسب لوظيفة المعلم والمرشـد. & 13 \\
\hline قليلة & 14 & 1.08 & 2.50 & تتناسب الحوافزوالراتب مع الجهود المبذولة للمعلم والمرشـد في المؤسسة & 14 \\
\hline متوسطة & & 0.57 & 2.94 & 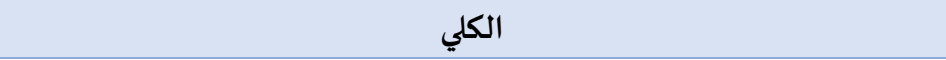 & \\
\hline
\end{tabular}

يتبين من الجدول (12) أن المتوسطات الحسابية لتقديرات عينة الدراسة لدرجة الرضا المادي بدرجة ممارسة من قليلة إلى كبيرة، وجاء أن الحوافز المدرسية تؤثر على المعلم والمرشد بصورة إنماته إيجابية خلال وجودها بالمدرسة في المرتبة الأولى بدرجة ممارسة كبيرة، في حين الحوافز والراتب تناسب الجهود المبذولة للمعلم والمرشد في المؤسسة التربوية بالمرتبة الأخيرة وبدرجة ممارسة قليلة، وبلغ المتوسط الحسابي الإجمالي لتقديرات عينة الدراسة

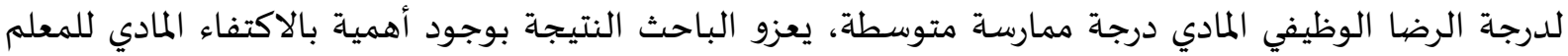

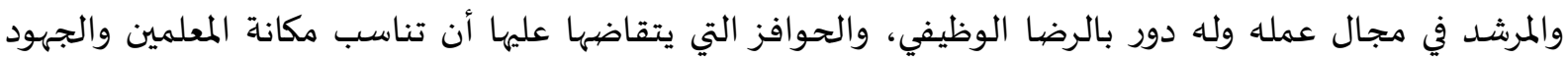
Shila ) المبذولة في العمل وتناسب سنوات الخبرة ليتحسن شعورهم بالرضا الوظيفي، وقد اختلفت النتائج مع دراسة

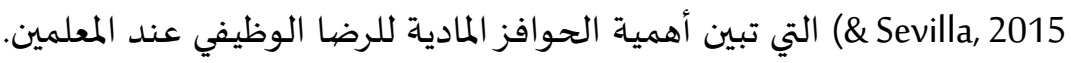

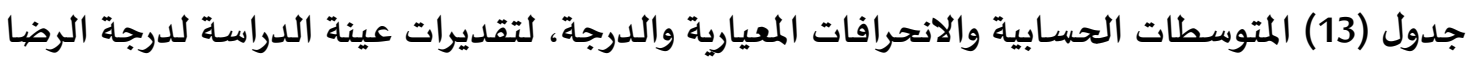

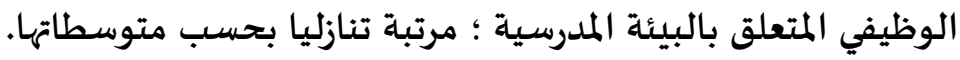

\begin{tabular}{|c|c|c|c|c|c|}
\hline الرضيا & 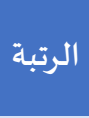 & المعياري & المتوسط الحسب & 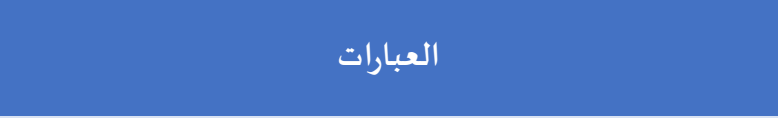 & $\hat{\imath}$ \\
\hline كبيرة & 1 & 0.80 & 4.27 & وجود الحدائق والزهور يؤثرعلى نفسية المعلمين والمرشـدين & 31 \\
\hline كبيرة & 2 & 0.71 & 4.28 & نظافة المؤسسات التربوية له أثر ايجابي على المعلمين والمرشدين & 28 \\
\hline كبيرة & 3 & 0.85 & 4.12 & الإقليم والمبنى الخارجي للمدرسة يؤثر على نفسيتي & 27 \\
\hline كبيرة & 4 & 0.92 & 3.74 & مدة الدرس تكفي لإعطاء المادة المطلوبة داخل الصفف & 37 \\
\hline كبيرة & 5 & 1.05 & 3.69 & مساحة الممدرسة تلائم عدد الطلاب الموجودين داخل المدرسة & 29 \\
\hline 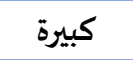 & 6 & 1.08 & 3.60 & تستطيع أن تتجول في المدرسة دون إزعاج من قبل الاخرين & 30 \\
\hline كبيرة & 7 & 1.01 & 3.57 & أشعر بأن أولياء الأمور لهم تأثير على إدارة المدرسة وقراراتها & 36 \\
\hline متوسطة & 8 & 1.12 & 3.39 & أشعر بالأمان الوظيفي & 32 \\
\hline متوسطة & 9 & 1.15 & 3.36 & يوجد تعاون مشترك بين الطاقم التربوي داخل المدرسة & 38 \\
\hline متوسطة & 10 & 1.13 & 3.33 & بناية المدرسة تلائم جميع المعلمين والمرشدين & 33 \\
\hline
\end{tabular}




\begin{tabular}{|c|c|c|c|c|c|}
\hline الرضة & 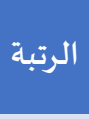 & الانحراف & المتوسط الحسبابي & 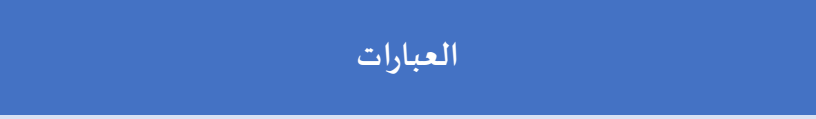 & $\hat{r}$ \\
\hline متوسطة & 11 & 1.08 & 3.31 & تتماشى مدرستي بالتغيرات والتقنيات الحديثة & 35 \\
\hline متوسطة & 12 & 1.06 & 3.25 & إدارة المدرسـة تراعي الظروف الخارجية وتتأثر بالعوامل المحيطة بها & 34 \\
\hline 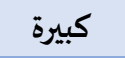 & & 0.63 & 3.66 & 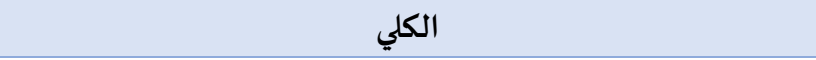 & \\
\hline
\end{tabular}

يتبين من الجدول (13) أن المتوسطات الحسابية لتقديرات عينة الدراسة لدرجة رضاهم عن البيئة

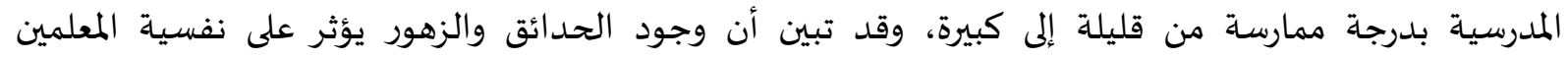

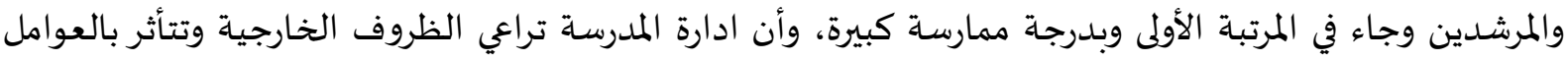

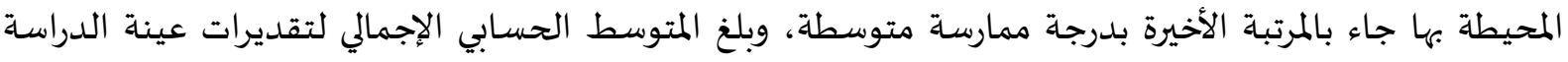

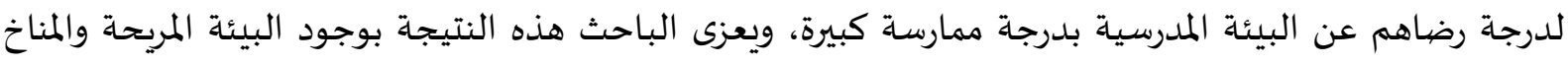

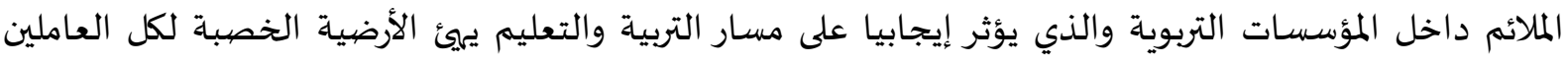

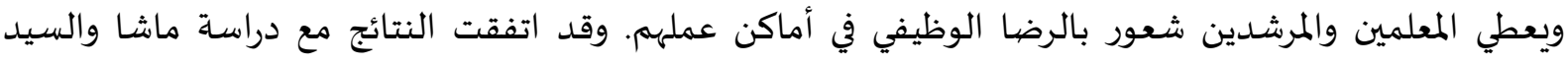

جدول (14) المتوسطات الحسابية والانحرافات المعيارية والدرجة، لتقديرات عينة الدراسة لدرجة الرضيا

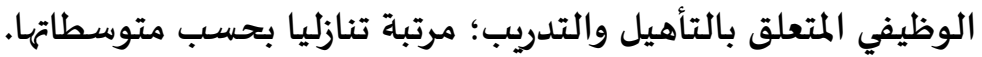

\begin{tabular}{|c|c|c|c|c|c|}
\hline 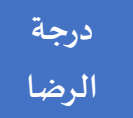 & 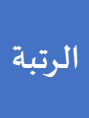 & 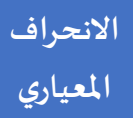 & المستوسط الحسبي & 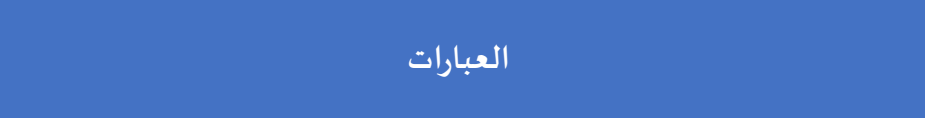 & s \\
\hline كبيرة & 1 & 0.90 & 3.72 & يتم تقديم الدورات التدريبية من قبل خبراء مختصين. & 43 \\
\hline كبيرة & 2 & 0.92 & 3.66 & يستخدم المحاضرون أساليب وأدوات متقدمة ومتطورة خلال الدورات & 47 \\
\hline كبيرة & 3 & 0.93 & 3.64 & يتم مواكبة العصروالتكنولوجيا خلال دورات التدريب. & 46 \\
\hline كبيرة & 4 & 0.91 & 3.60 & يؤخذ بعين الاعتبار التغيرات من خلال تمرير دورات التدريب والتأهيل. & 45 \\
\hline كبيرة & 5 & 0.96 & 3.59 & تساهم الدورات التعليمية في توسيع أفكاري مما يؤثر على نجاحي بالمدرسة & 41 \\
\hline كبيرة & 6 & 0.94 & 3.58 & تكون أهداف البرامج التدريبية شمولية ومتنوعة. & 49 \\
\hline كبيرة & 7 & 0.98 & 3.57 & تساعدني الدورات التعليمية في التقدم والتطور داخل المدرسسة. & 40 \\
\hline كبيرة & 8 & 0.93 & 3.54 & يتم الملائمة بين دورات التدريب والتأهيل والحاجات الممدرسية. & 44 \\
\hline كبيرة & 9 & 0.96 & 3.52 & إبداعات المعلمين والمرشدين تتأثر بالدورات التدريبية. & 42 \\
\hline كبيرة & 10 & 1.00 & 3.47 & الدورات التعليمية التي تعطى للمعلمين تلائم الحاجات المدرسية. & 39 \\
\hline كبيرة & 11 & 1.00 & 3.45 & تتفهم الممدرسة حاجات المعلمين والمرشدين بتحديدها لدورات معينة لذلك. & 48 \\
\hline متوسطة & 12 & 1.09 & 2.71 & أشعر بوجود فراع بين محتوى دورات التدريب والتأهيل وبين المؤسسات & 50 \\
\hline 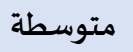 & & 0.70 & 3.21 & الكلي & \\
\hline
\end{tabular}

يتبين من الجدول (14) أن المتوسطات الحسابية لتقديرات عينة الدراسة لدرجة الرضا عن التأهيل والتدريب جاءت بدرجة ممارسة من متوسطة إلى كبيرة، وتبين أن تقديم الدورات التدريبية من قبل خبراء مختصين

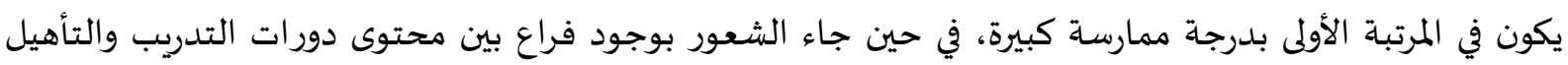

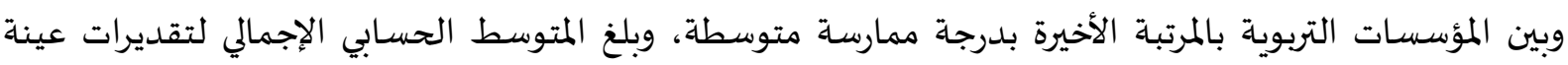
الدراسة لدرجة رضاهم عن التأهيل والتدريب درجة ممارسة متوسطة، ويعزو الباحث النتيجة بأن الخبراء

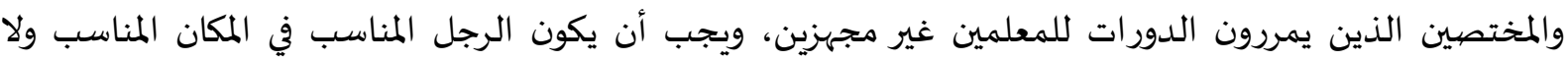


يملكون الخبرة الكافية لتأهيل وتدريب المعلمين ولم تستغل هذه الدورات كما يجب، ويوجد تقصير من قبلهم، والذي

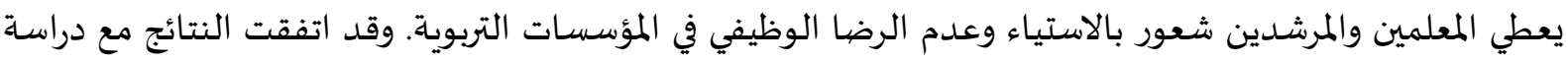

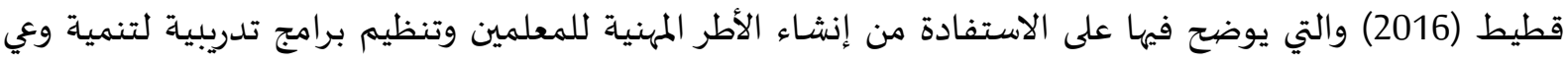

جدول (15) المتوسطات الحسابية والانحرافات المعيارية والدرجة، لتقديرات عينة الدراسة لدرجة الرضيا الوظيفي المتعلق بالقيادة؛ مرتبة تنازليا بحسب متوسطاتها.

\begin{tabular}{|c|c|c|c|c|c|}
\hline 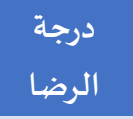 & 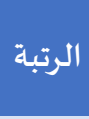 & 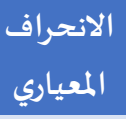 & المتوسط & 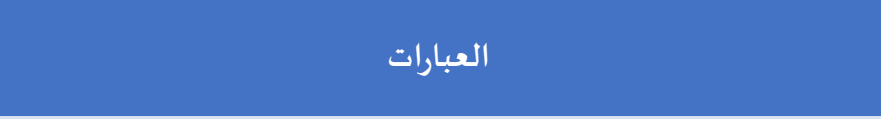 & $\hat{\imath}$ \\
\hline 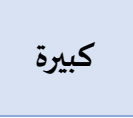 & 1 & 1.01 & 3.52 & تتأثر القيادة بالعوامل والبيئة الخارجية ويؤثر ذلك سلبا على نتائج & 4 \\
\hline 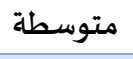 & 2 & 1.06 & 3.25 & تعتبر الإدارة متابعة لجميع الأمور المدرسية. & 10 \\
\hline 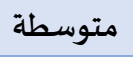 & 3 & 1.19 & 3.10 & تنمي روح التعاون بين المعلمين والمرشدين وبين الإدارة. & 7 \\
\hline متوسطة & 3 & 1.15 & 3.10 & تتعامل الإدارة بروح الفريق والعمل المشترك. & 5 \\
\hline 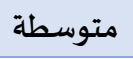 & 5 & 1.20 & 3.06 & تتعامل إدارة المدرسة معي بوضوح وشفافية. & 12 \\
\hline 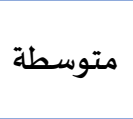 & 6 & 1.12 & 3.04 & تحرص على الرضا الوظيفي لدى المعلمين والمرشدين وتوفر اللوازم التي & 11 \\
\hline 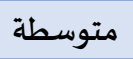 & 7 & 1.14 & 3.03 & تتابع وتسمع مشاكل المعلمين والمرشدين وتحاول معالجتها. & 8 \\
\hline 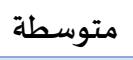 & 8 & 1.14 & 3.00 & تشارك المعلمين في اتخاذ القرارات المدرسية & 6 \\
\hline 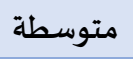 & 9 & 1.17 & 2.99 & الإدارة تركز على النمط القديم ولا تواكب التكنولوجيا والتطور. & 3 \\
\hline متوسطة & 10 & 1.22 & 2.85 & تتبع سياسة فرق تسد ولا هـتم بالعمل المشترك داخل المؤسسة التربوية. & 9 \\
\hline 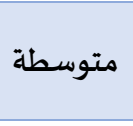 & 11 & 1.20 & 2.78 & القيادة المدرسية لا تهتم بالأعمال الفنية والإبداع وتركز على الأعمال & 2 \\
\hline 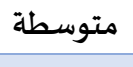 & 12 & 1.24 & 2.71 & أشعر بأن عملي لا يُلقى تقديرا من قبل الإدارة. & 1 \\
\hline 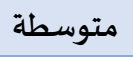 & & 0.78 & 3.04 & 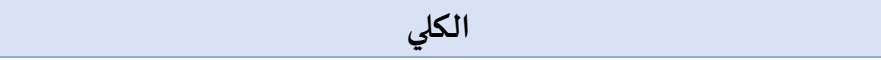 & \\
\hline
\end{tabular}

وبينت نتائج جدول (15) أن المتوسط الحسابي الإجمالي لتقديرات عينة الدراسة لدرجة الرضا من القيادة

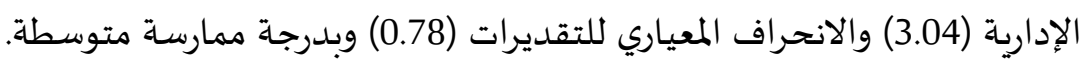

مناقشَة النتائج المتعلقة بالسؤال الثالث: هل هناك فروق ذات دلالة إحصائية عند مستوى (X=0.05) في

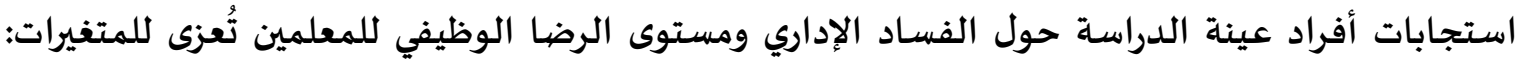

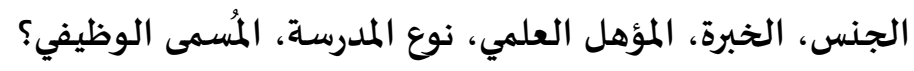

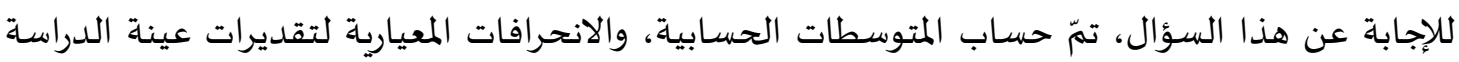

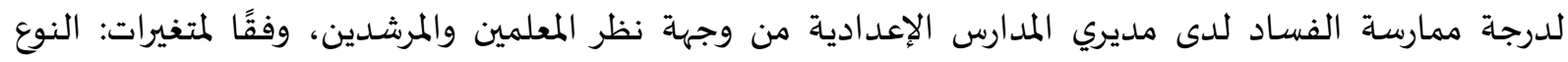

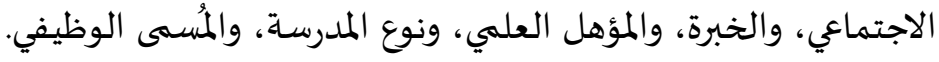


الجدول (16) المتوسطات الحسابية، والانحرافات المعيارية لتقديرات عينة الدراسة لدرجة ممارسة الفساد

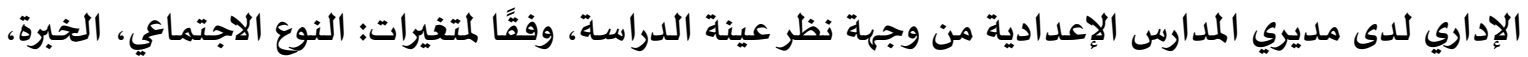

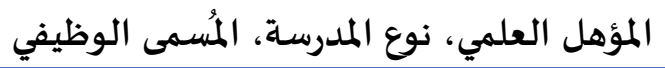

\begin{tabular}{|c|c|c|c|c|c|c|c|}
\hline المعياري & المتوسط الحسابي & المتابع & الانحراف & المستوسط الحسبي & مستويات المتفير & المستقل & المتغير \\
\hline 0.53 & 3.18 & \multirow{11}{*}{ فساد المرافق } & 0.83 & 3.42 & ذكر & \multirow{2}{*}{ الاجتماعي } & \multirow{11}{*}{ المادي المساد } \\
\hline 0.68 & 2.99 & & 0.98 & 3.25 & أنثى & & \\
\hline 0.70 & 3.22 & & 1.08 & 3.53 & مرشد & \multirow{2}{*}{ المسمى الميفي } & \\
\hline 0.62 & 3.01 & & 0.90 & 3.26 & معلم & & \\
\hline 0.66 & 3.01 & & 0.99 & 3.46 & أقل من 5 سنوات & \multirow{3}{*}{ الخبرة } & \\
\hline 0.66 & 3.05 & & 0.88 & 3.27 & بين 5- 10 سنوات & & \\
\hline 0.63 & 3.06 & & 0.94 & 3.28 & أكثر من 10 سنوات & & \\
\hline 0.62 & 2.96 & & 0.92 & 3.30 & بكالوريوس & \multirow{2}{*}{ المؤهل } & \\
\hline 0.65 & 3.12 & & 0.95 & 3.31 & ماجستير & & \\
\hline 0.64 & 2.94 & & 0.82 & 3.19 & خاصة & \multirow{2}{*}{ المدرسة } & \\
\hline 0.64 & 3.07 & & 0.95 & 3.32 & حكومية & & \\
\hline & & & 0.81 & 3.92 & ذكر & \multirow{2}{*}{ الاجتماعي } & \multirow{11}{*}{ الموظفين } \\
\hline & & & 0.90 & 3.66 & أنثى & & \\
\hline & & & 0.91 & 3.73 & مرشد & \multirow{2}{*}{ المسمى الميفي } & \\
\hline & & & 0.87 & 3.75 & معلم & & \\
\hline & & & 0.77 & 3.67 & أقل من 5 سنوات & \multirow{3}{*}{ الخبرة } & \\
\hline & & & 0.81 & 3.70 & بين 5- 10 سنوات & & \\
\hline & & & 0.93 & 3.79 & أكثر من 10 سنوات & & \\
\hline & & & 0.84 & 3.64 & بكالوريوس & \multirow{2}{*}{ المؤهل } & \\
\hline & & & 0.91 & 3.83 & ماجستير & & \\
\hline & & & 0.84 & 3.46 & خاصية & \multirow{2}{*}{ المدرسة } & \\
\hline & & & .88 & 3.79 & حكومية & & \\
\hline & & & 0.59 & 3.35 & ذكر & \multirow{2}{*}{ الاجتماعي } & \multirow{2}{*}{ فساد } \\
\hline & & & 0.72 & 3.08 & أنثى & & \\
\hline
\end{tabular}

وقد أظهرت النتائج إلى عدم وجود أثر دال إحصائيًا لمتغيرات: النوع الاجتماعي، والخبرة، والمؤهل العلمي،

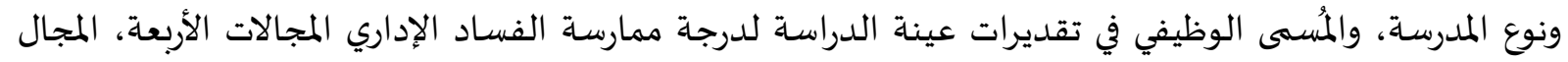
المادي، مجال الموظفين، مجال المعاملات، مجال المرافق، لدى مديري المدارس الإعدادية من وجهة نظر المعلمين والمرشدين. فقد كشفت النتائج عن وجود فرق دال إحصائيًا بين متوسطي تقديرات عينة الدراسـة للفساد بين

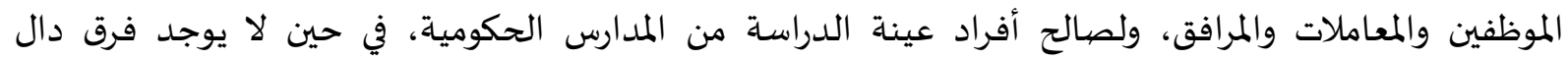

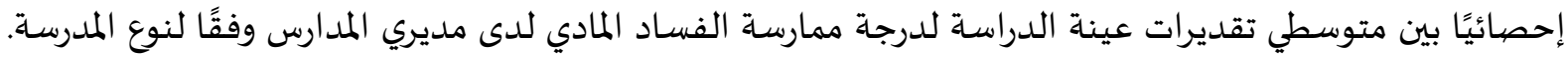


يعزو الباحث ذلك لكون المدارس الحكومة شاملة من جميع الأطياف وجميع المستويات والذي يعطي

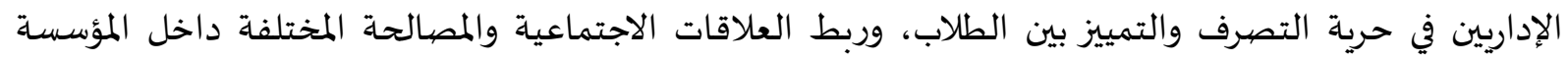

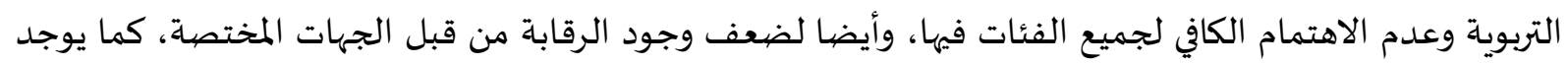

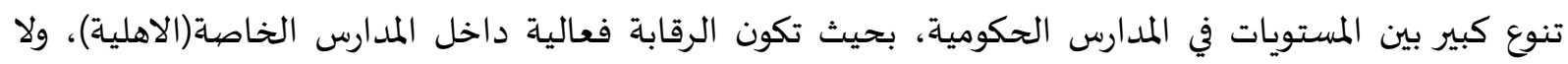
يستطيع الإداري التصرف كما يحلو له، وغالبية الطلاب يكونوا من المستويات العالية، والأهالي يتابعون أبنائهم وينفقون عليهم الأموال ليكونوا أبنائهم من المتعلمين.

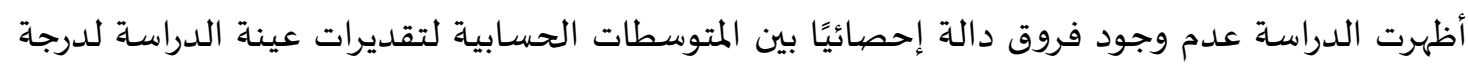

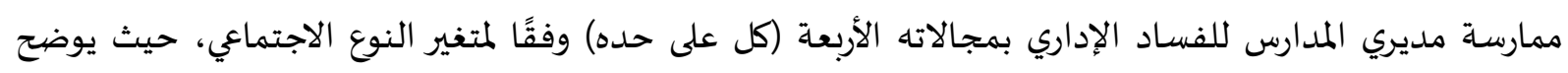

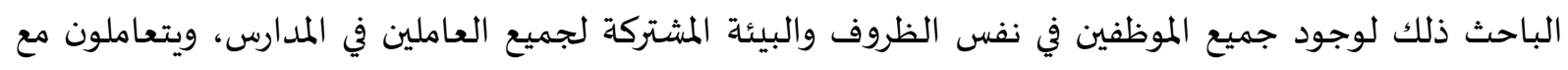
الإداري من منطلق المعرفة المسبقة للمجتمع والبيئة المحيطة به، وتحديدهم للفساد الإداري في مدارسههم، وأيضا

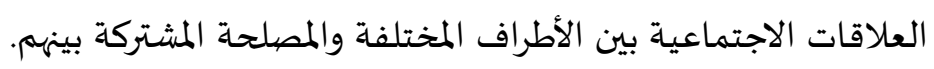

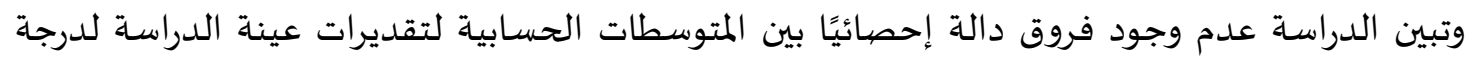
ممارسة مديري المدارس للفساد الإداري بمجالاته الأربعة (كل على حدة)، وفقًا لمتغير المؤهل العلمي. يحث يعزو الباحث هذه النتيجة لكون المعلمين أصحاب الشهادات المختلفة هم اكفاء وعندهم المعرفة المادية

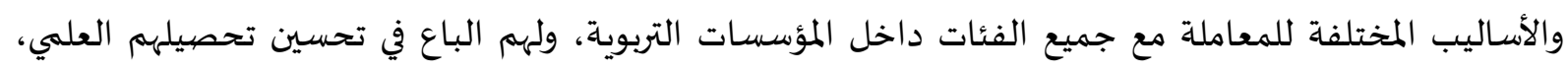

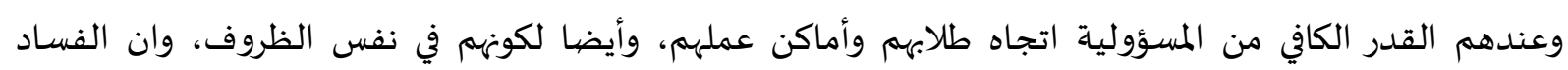
الإداري لا علاقة له بالمؤهلات العلمية.

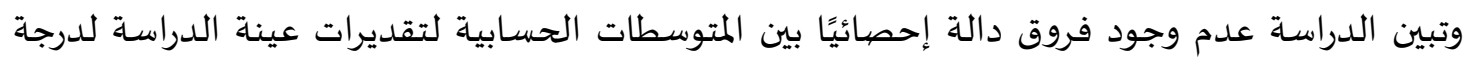

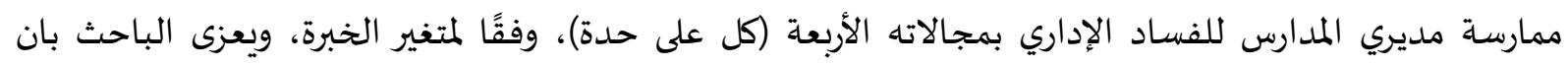

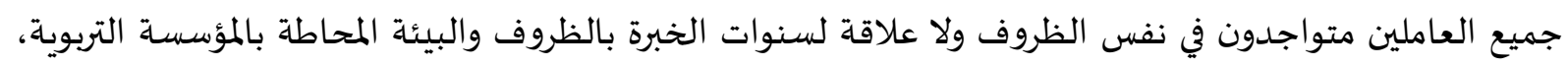

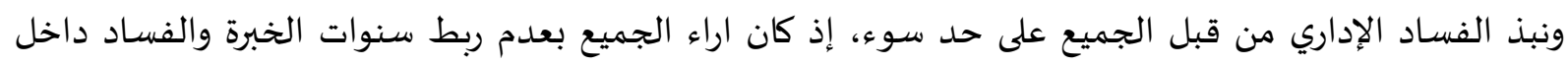
مدارسهم. عدم وجود فروق دالة إحصائيًا بين المتوسطات الحسابية لتقديرات عينة الدراسة لدرجة ممارسة مديري

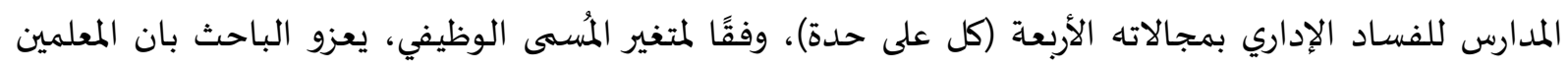

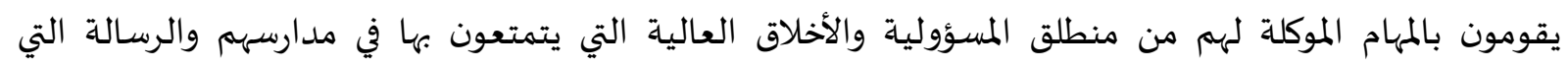

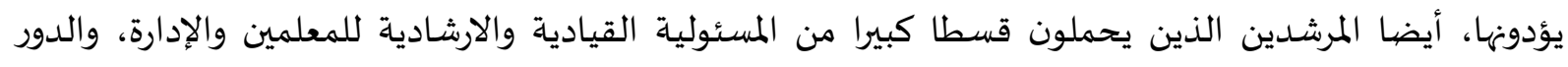

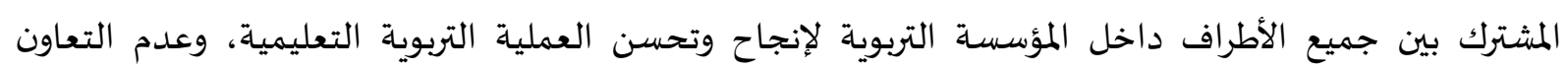

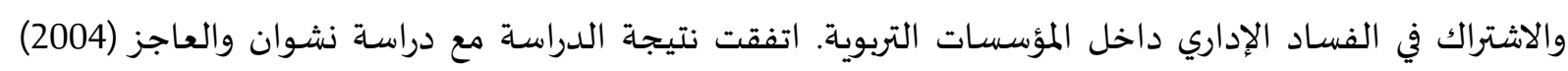
والتي أظهرت سلامة النظام والانضباط المدرسي بالنسبة للمعلمين، كما اتفقت مع نتائج دراسة قطيط الإدل (2016).

مناقشة النتائج المتعلقة بالسؤال الرابع: هل هناك فروق ذات دلالة إحصائية عند مستوى (0.05 )

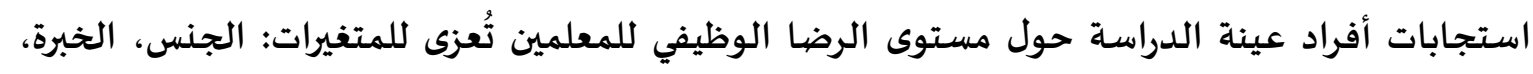

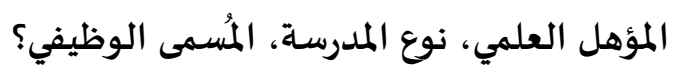

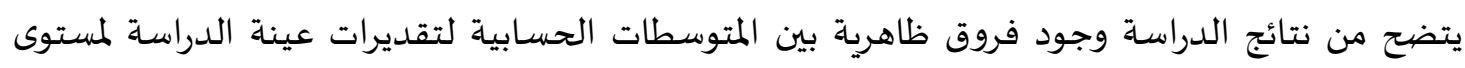

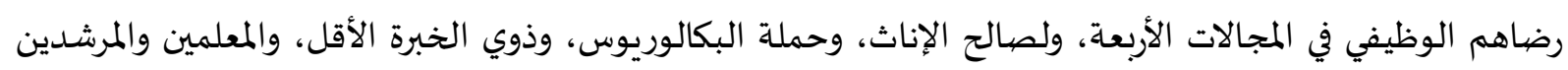


من المدارس الخاصة. كما يلاحظ وجود فروق ظاهرية بين المتوسطات الحسابية لتقديرات عينة الدراسة لمستوى

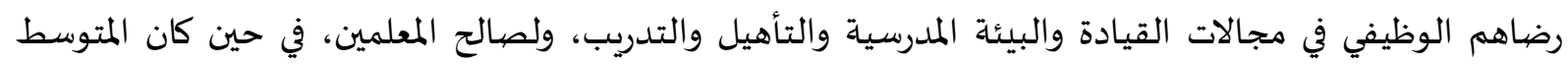
الحسابي لتقديرات المرشدين في مجال الرضا المادي أعلى منه لدى المات المعلمين.

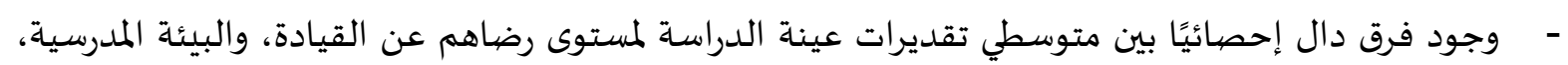

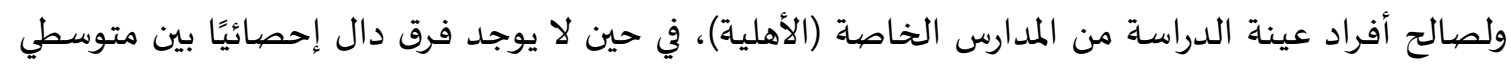
تقديرات عينة الدراسة لمستوى رضاهم المادي والتأهيل والتدريب.

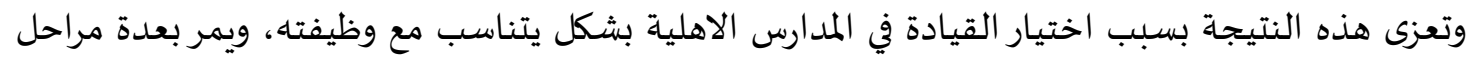

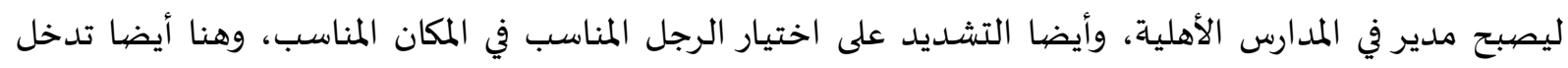

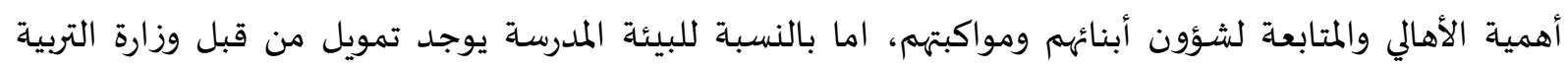

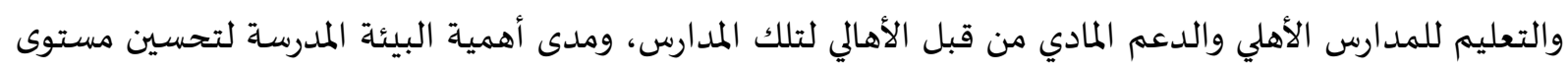

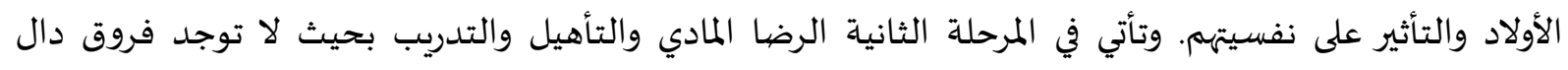

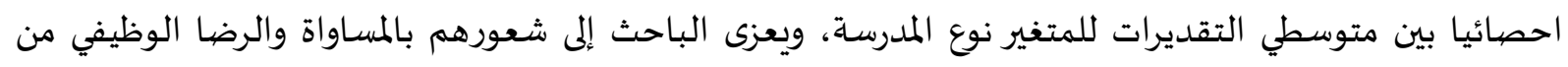

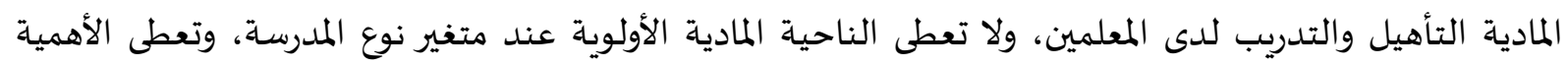

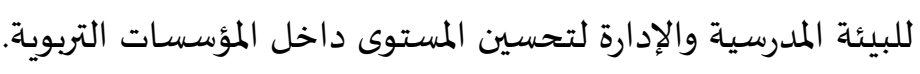

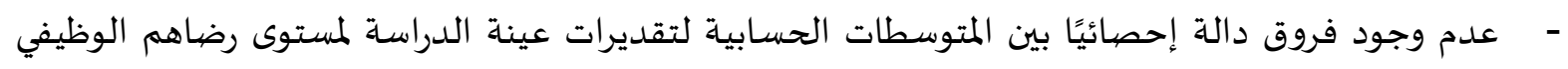

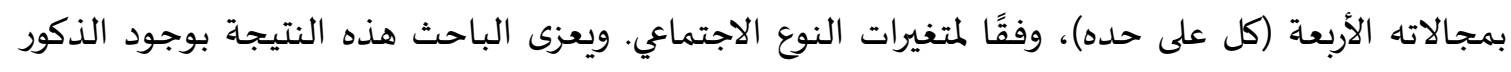

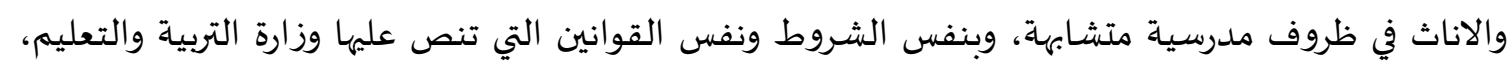

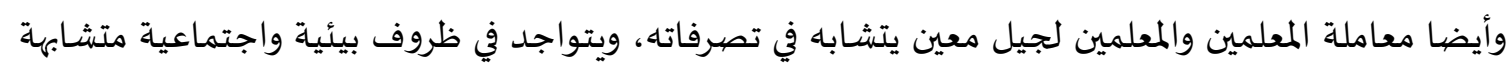

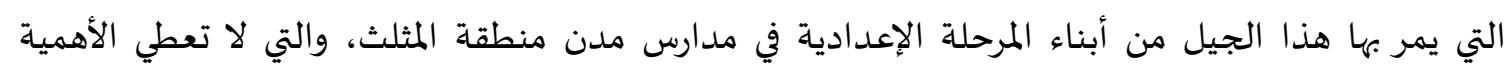

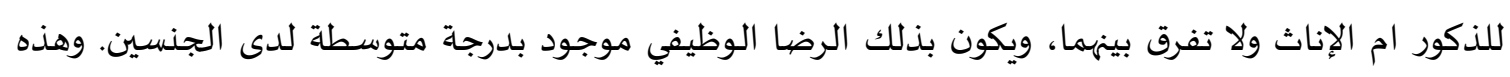

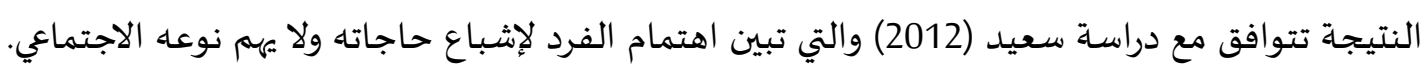

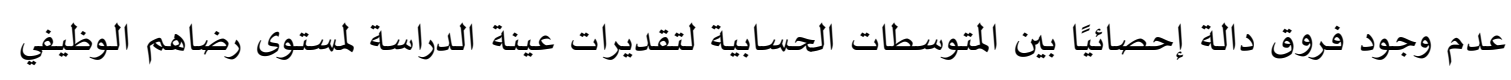

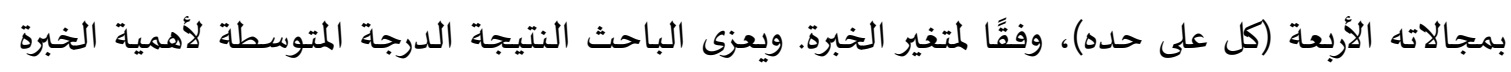

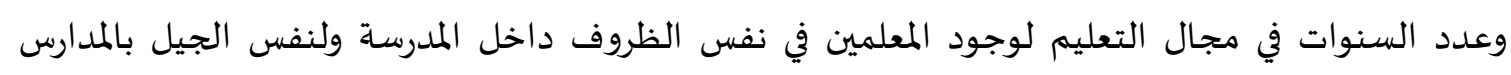

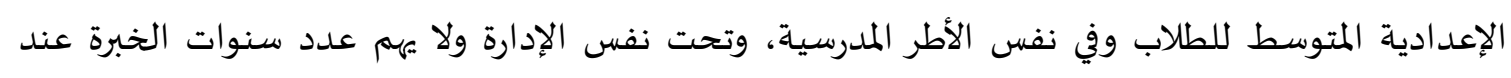

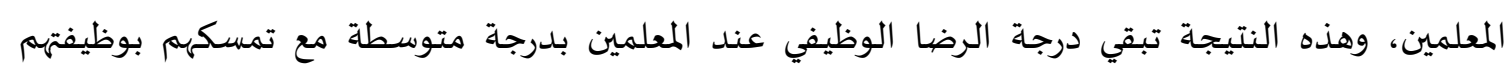

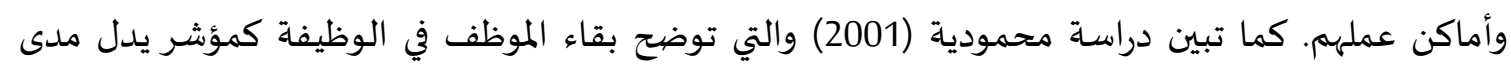
ارتباطه بعمله. عدم وجود فروق دالة إحصائيًا بين المتوسطات الحسابية لتقديرات عينة الدراسة لمستوى رضاهم الوظيفي

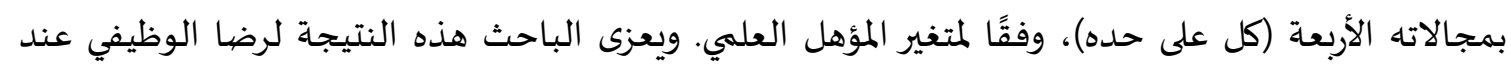

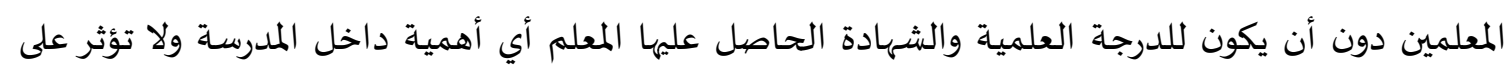

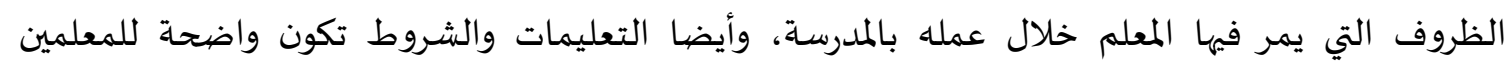

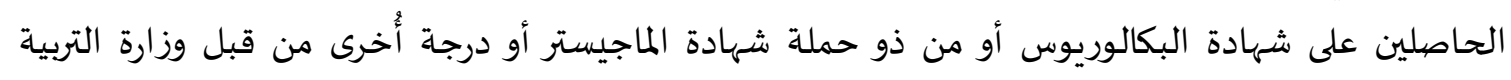

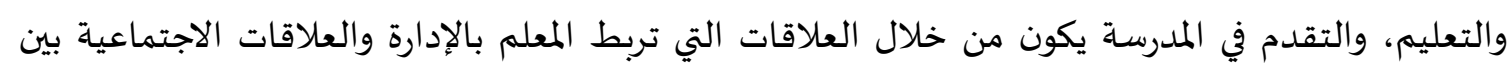


الأطراف المختلفة ولا علاقة لذلك بالتحصيلات العلمية والشهادات الحاصل عليها المعلم، ولهذه الأسباب تبين النتيجة بأن الرضا الوظيفي للمعلمين موجودة بدرجة متوسطة عند الجميع. عدم وجود فروق دالة إحصائيًا بين المتوسطات الحسابية لتقديرات عينة الدراسة لمستوى رضاهم الوظيفي

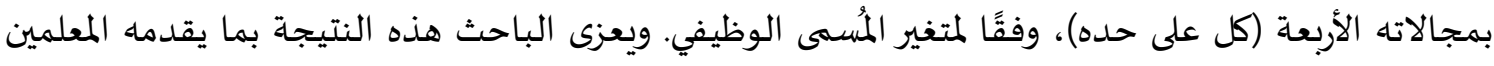

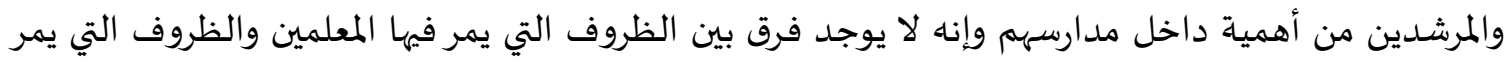

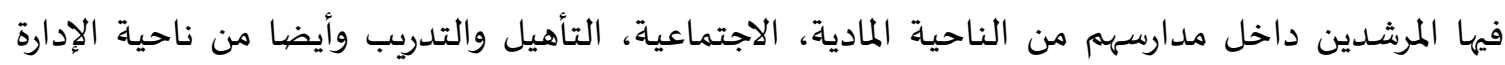
والقيادة، والتي تبين الدرجة المتوسطة للرضى الوظيفي للمتئير.

النتائج المتعلقة بالسؤال الخامس: هل توجد علاقة ارتباطية دالة احصيائياً عند مستوى (Q=0.05) بين

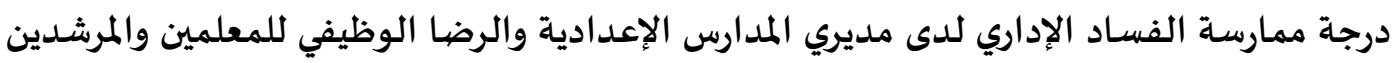

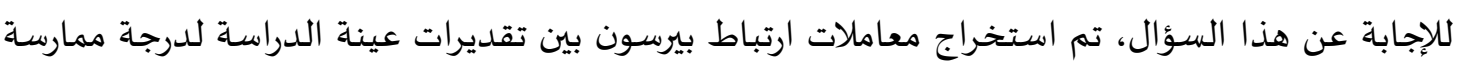

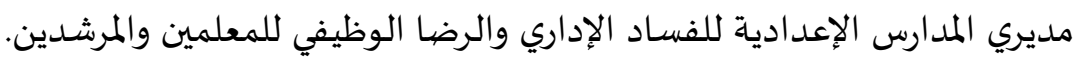
الجدول (16): معاملات ارتباط بيرسون بين تقديرات عينة الدراسة لدرجة ممارسة مديري المدارس الإدراسية الإعدادية

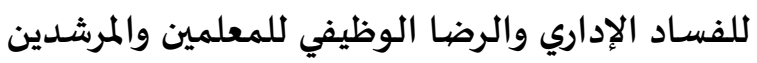

\begin{tabular}{|c|c|c|c|c|c|c|}
\hline & & & \\
\hline \\
\hline
\end{tabular}

( $\alpha=0.05) . ذ$ ذات دلالة إحصائية عندرند يبين الجدول (16) ارتباط الرضا عن البيئة المدرسية بعلاقة سلبية دالة إحصائيًا بالفساد المادي ( r= -0.28

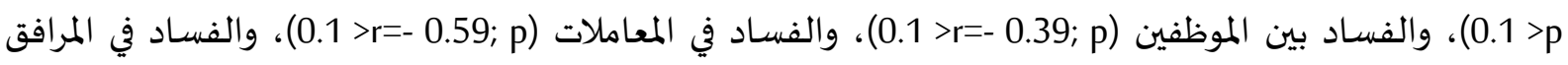
(0.1>r=- 0.54; p)

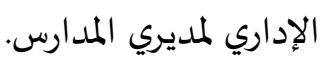

يرتبط الرضا عن التأهيل والتدربب بعلاقة سلبية دالة إحصائيًا بالفساد المادي (r=-0.28) ،

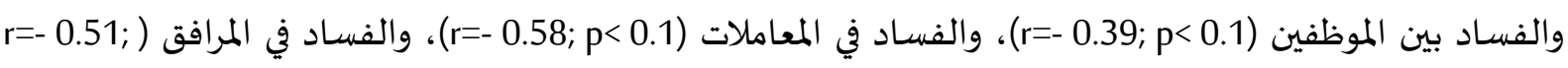
1p >0.1). وعليه، تقل تقديرات عينة لمستوى رضاهم عن التأهيل والتدريب بزيادة مستوى تقديراتهم للفساد الإداري لمديري المدارس. 
يرتبط الرضا عن القيادة بعلاقة سلبية دالة إحصائيًا بالفساد المادي (r=0.0.58)،

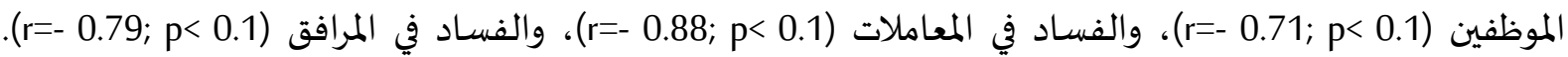

وعليه، تقل تقديرات عينة لمستوى رضاهم عن القيادة بزيادة مستوى تقديراتهم للفساد الإداري لمديري المدارس.

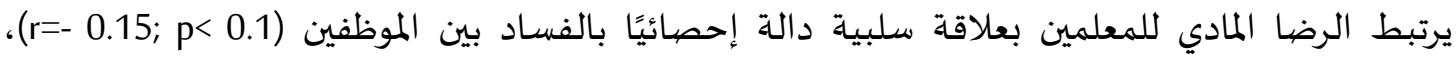

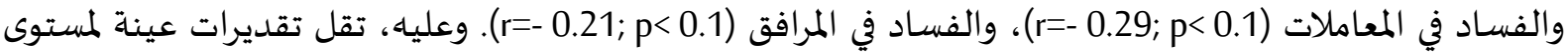
رضاهم المادي بزيادة مستوى تقديراتهم للفساد الإداري (الموظفين، والمعاملات، والمرافق) لمديري المدارس. في حين لا توجد علاقة دالة إحصائيًا بين الرضا المادي والفساد المادي. ويعزى الباحث هذه النتيجة بان الفساد الإداري ينعكس طرديا على الرضا الوظيفي للمعلمين والمرشدين عن البيئة المدرسية، عن التأهيل والتدريب، عن القيادة، أي كل ما زاد الفساد الإداري بالمؤسسات التربوية يقل الرضا الوظيفي عند المعلمين والذي يؤثر على أهداف العملية التربوية في المدارس الإعدادية في منطقة مدن المثلث داخل الخط الاخضر. ويعزو الباحث عدم وجود العلاقة الارتباطية بين الرضا المادي للمعلمين والفساد المادي حيث لا يتأثر المعلمين بشكل مباشر من الفساد المادي المتواجد داخل المدارس، وهذه النتائج توافق دراسة عزب عزب (2011) واتفقت مع دراسة الشمري والفتلي (2011) وأيضا مع دراسـة بن زوة (2017).

التوصيات والمقترحات:

استناداً إلى نتائج الدراسة التي تم التوصل الهيها، يوصي الباحثان ويقترحان الآتي: 1- وضع استراتيجية واضحة في المؤسسات التربوية مبنية على معايير دقيقة وشفافية، والعمل على توفير وتعزيز المبادئ والقيم والأخلاق من خلال تكثيف الجهود المبذولة والرقابة على المؤسسات المبهدية التربوية.

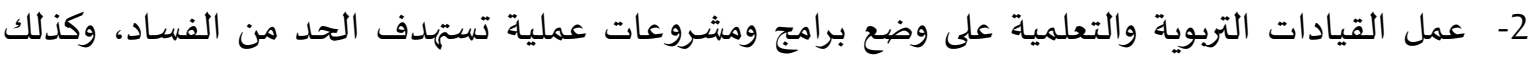

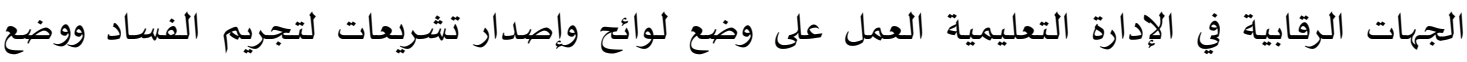
عقوبات رادعاة. تشكيل مجالس رقابية وزيادة مشاركة المجتمع في أنشطة وبرامج المدرسة والإشراف عليعاف عليها، بما يحد من الفساد. 3- توفير مناخ منظمي تربوي تعليمي في المؤسسات التربوية يعكس حالة الترابط بين الأهداف المطروحة من قبل

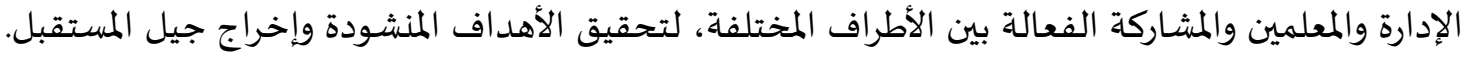

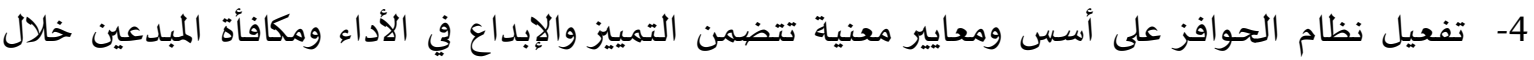

$$
\text { تطويرهم وتقدمهم في المؤسسات التربوية. }
$$

5- تحسين الظروف الاجتماعية والمادية للمعلمين، وتوفير لهم سُبل الراحة ليتسنى لهم تكريس غالبية أوقاتهم

$$
\text { 6- إجراء دراسات مشابهات التربية ولعملهم. وزيادة الدعم المقدم للمدارس. }
$$

- ابن منظور، أبو الفضل جمال الدين بن مكرم. (2005). لسان العرب. بيروت: دار صادر. المجلد 05، ط (4)، 
- أحمدية، نصير وعلي، جرمون والماحي، قصار. (2019). تقدير مستوى الرضا الوظيفي وعلاقته بدافعية الانجاز

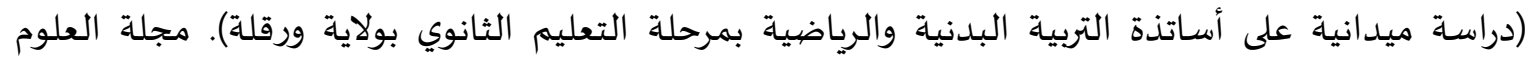

الإنسانية والاجتماعية، 2 (5).

باجة، حميد. (2014). دور التحفيز في تحقيق الرضا الوظيفي. ماجستير غير منشورة، جامعة نزوى، سلطنة عمان.

بن زوة، أحلام. (2017). ممارسة مديري المدارس الابتدائية لأساليب إدارة التغيير وعلاقتها بمستوى الرضا الوظيفي لدى المعلمين من وجهة نظرهم. رسالة ماجستير غير منشورة. كلية العلوم الإنسانية والاجتماعية، الإدان. جامعة العربي بن مهيدي، الجزائر. بن موفق الميلود وبن صافي عبد الكريم. (2016). الرضا الوظيفي وأثره على أداء المعلم. رسالة دكتورة غير المراتر

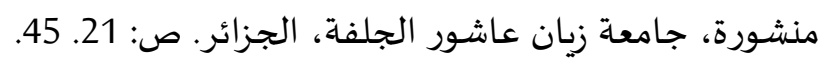

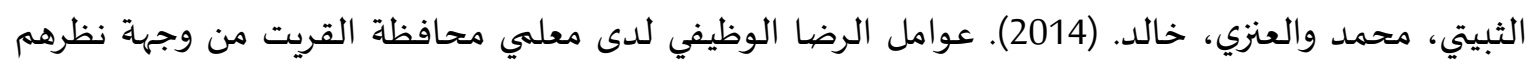

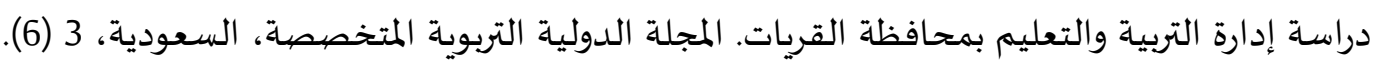
الجاعوني وخليل، فريد. (2009). دراسة إحصائية وصفية لتحليل مؤشرات الفساد المالي والإداري وأثرها في

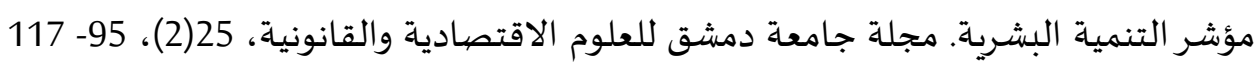

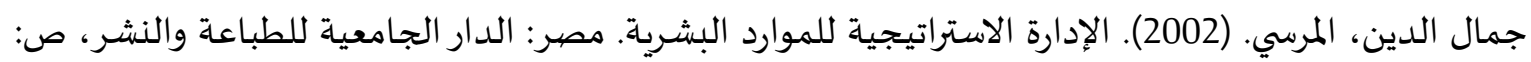
$.29-30$

الحديدي، عماد امين. (2020). دور الحكومة الإدارية في مكافحة الفساد الإداري في وزارة التربية والتعليم العالي المدادي

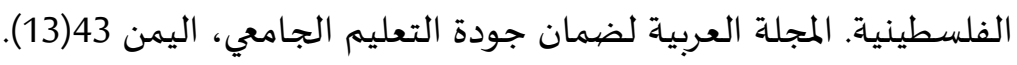
خالد عبد الرحمن بن حسن بن عمر ال الشيخ. (2007). الفساد الإداري: أنماطه وأسبابه وسبل الفيل مكافحتها. الرياض، جامعة نايف العربية للعلوم الأمنية. درة، عبد الباري والصباغ، زهير. (2010). إدارة الموارد البشرية في القرن الحادي والعشرين. دار وائل للنشر: الأردن. الديحاني، سلطان غالب. (2017). تأثير الرقابة والشفافية الإدارية في مكافحة الفساد الإداري بالمناطق التعليمية

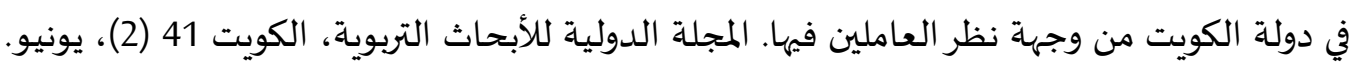

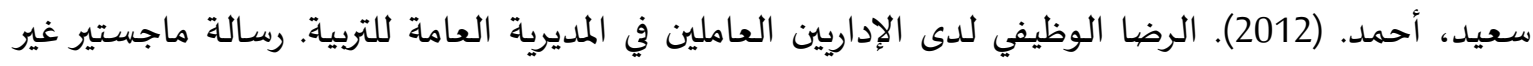
منشورة، جامعة نزوى، سلطنة عمان. شقير، علاء. (2011). درجة ممارسة مديري المدارس الحكومية ومديراتها للقيادة التشاركية وعلاقتها بالرضا

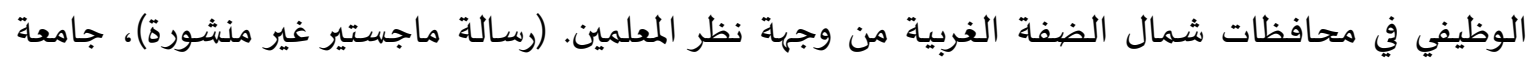
النجاح، الخليل، فلسطين. الشمري، هاشم و الفتلي، إيثار. (2011). الفساد الإداري والمالي واثاره الاقتصادية والاجتماعية. عمان: اليازوري للنشر والتوزع. صالح، بن سيف. (2002). أثر العوامل الوظيفية والشخصية على الرضا الوظيفي وكفاءة الأداء. السعودية: ط .62: (1) - صلاح الدين. (2001). السلوك التنظيمي. دار الجامعية للطباعة والنشر: ط (1) ص211. 
- الصوص، نداء محمد. (2011). السلوك الوظيفي .ط1، عمان: مكتبة المجتمع العربي للنشروالتوزيع.

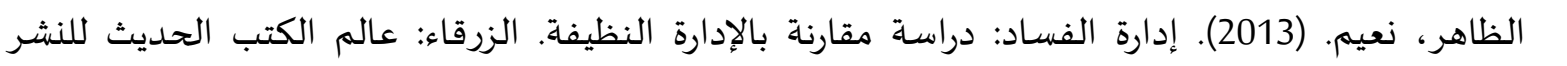
والتوزع. العاجزونشوان. (2004). عوامل الرضيا الوظيفي وتطوير فعالية اداء المعلمين بمدارس وكالة الغوث الدولية. غزة، الجامعة الإسلامية. عبد المنعم، سليمان. (2007). ظاهرة الفساد: دراسة في مدى مواءمة التشريعات العربية لحكام اتفاقية الامم المتحدة.

عزب، محمد علي. (2011). التعليم الجامعي وقضايا التنمية. القاهرة، كلية التربية، مكتبة انجلو المصرية.

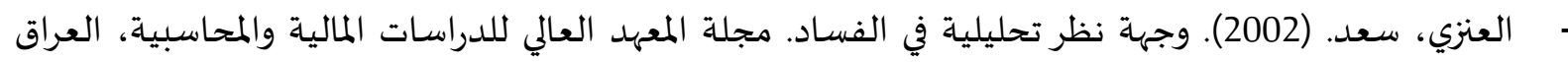
العدد (6)، السنة الثانية / آب. فرحان، وجيه. (2010). قضايا في الإدارة التربوية والمدرسية والصفية. الأردن: الوراق للنشروالتوزيع.

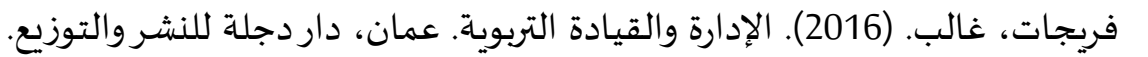

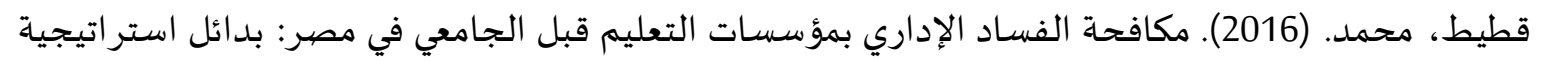

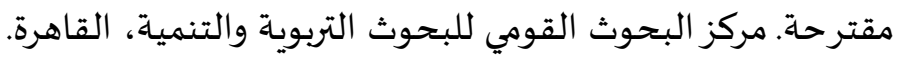

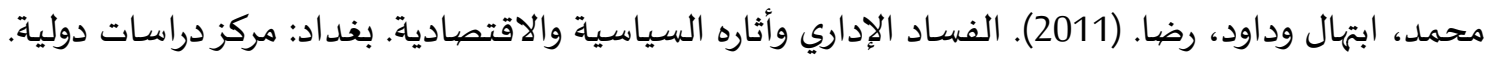

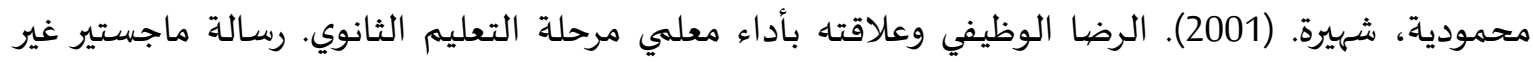

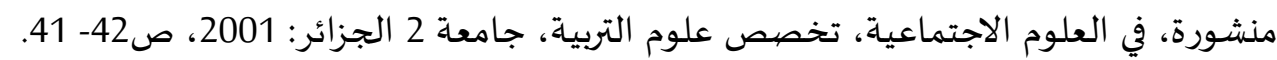

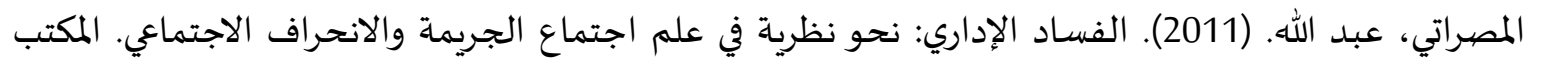
العربي الحديث: الإسكندرية. ميزروتسكي، ههوديت. (1997). مسيرة نحو الديمقراطية في إسرائيل. القدس: مركز المناهج التعليمية.

ثانياً- المراجع بالإنجليزية:

- Cronbach, L. J. (1951). Coefficient Alpha and the Internal Structure of Tests. Psychometrika, 16(3), 297- 334 .

- Genelyn R. Baluyos, Helen L. Rivera, Esther L. Baluyos. (2019). Teachers' Job Satisfaction and Work Performance. Open Journal of Social Sciences: Vol.7 No.8, August 20.p210- 211.

- Mahsa, K.and Seyed, A. (2018). The Relationship between Job Motivation and Organizational Climate with Administrative Corruption between Khorrambid Municipal Employees. American Journal of Psychology and Cognitive Science: Vol. 4, No. 2, 2018, pp. 17- 21

- Ozdemir, Murat (2013). "The Relationship of Organizational Corruption with Organizational Dissent and Whistleble Owing in Turkish School" Cukurova University Facully of Education Journal, 42

- Rumyantseva, Natalya L. (2005). Taxonomy of Corruption in Higher Education. Peabody Journal of Education, 80(1),18- 92.

- Shila, J.M. and Sevilla, A.V. (2015). The Influence of Teachers' Job Satisfaction on Their Organizational Commitment: An Indian Context. International Journal of Education and Management Studies, 53- 57. 